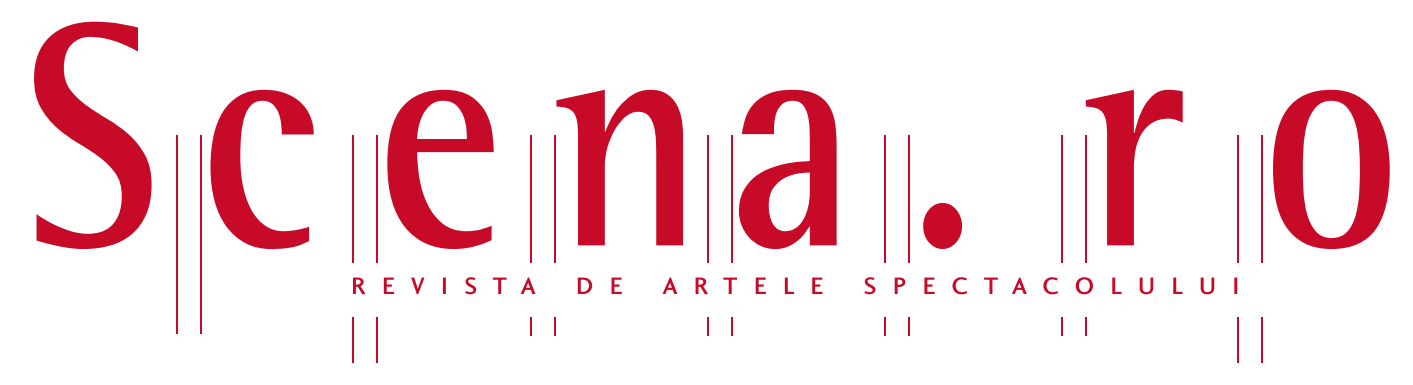

Nr. 5 noiembrie 2009

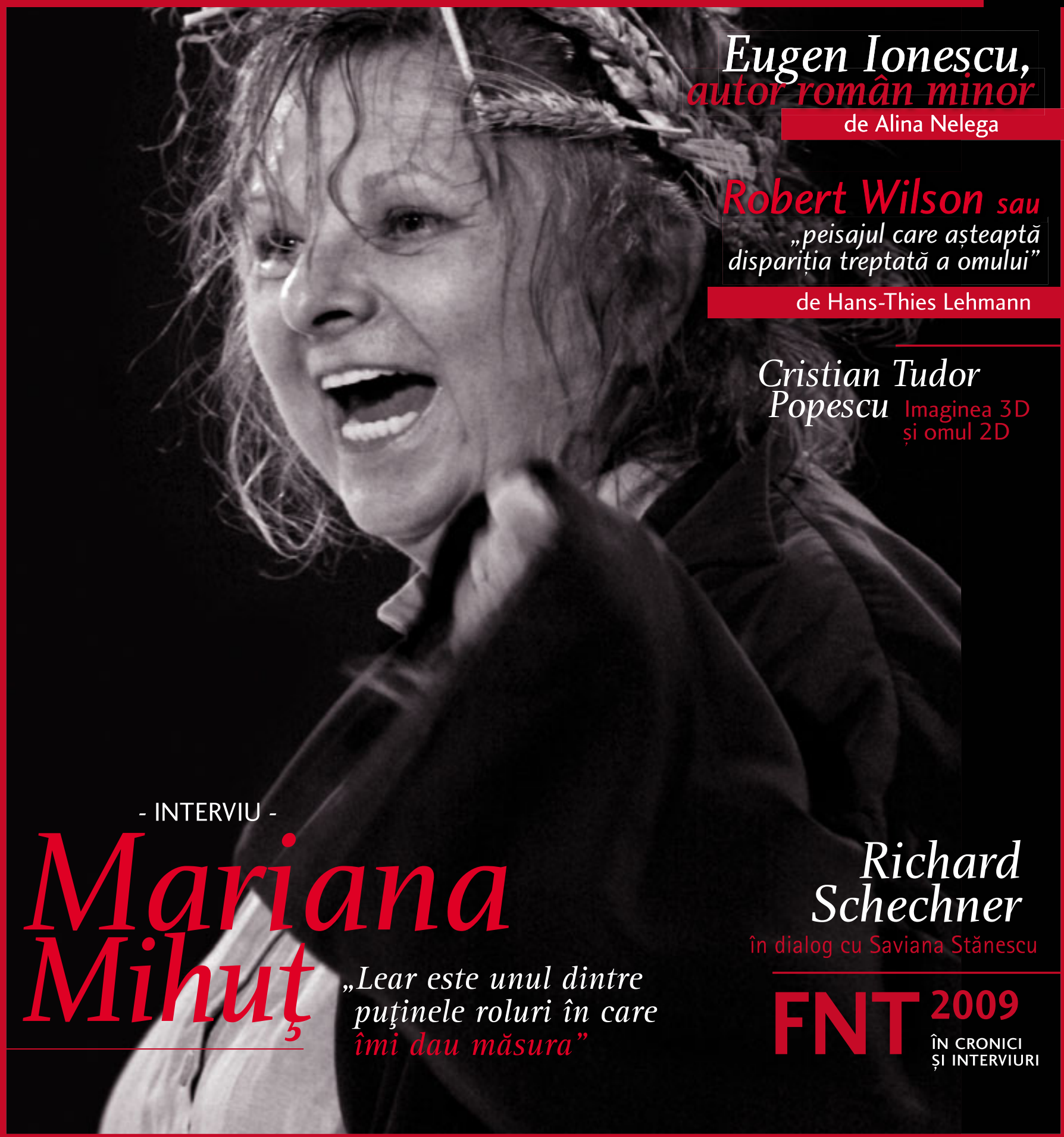

$\mid$
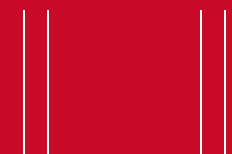
furtuna

Cu: Ioan Coman, Ada Simionică, Andi Vasluianu,Florentina Năstase,

Ionut Vişan, Tudor Smoleanu,

Bogdan Farcaş, Mihai Coadă,

Niculae Urs,Dragoş Câmpan,

Ilie Gâlea, Roxana Ivanciu,

Cristina Moldoveanu, Mihaela Popa.

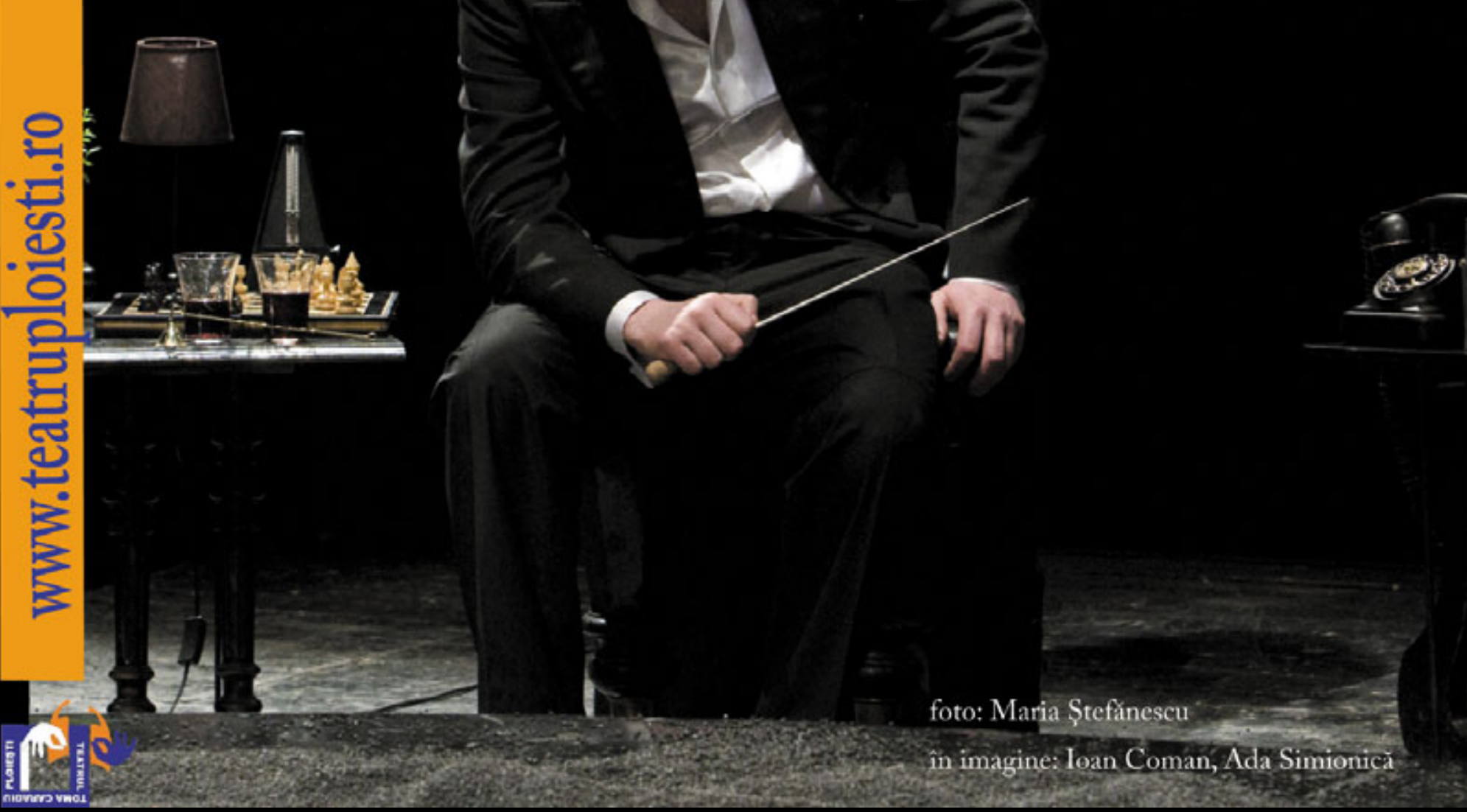




\section{Living theatre}

$T^{T}$ he editor in chief of Scena.ro proudly presents its fifth issue dedicated to a major event in Bucharest and the most important theatre festival in the country, a festival that in 19 years of existence has resisted in an unstable society and has developed into a platform of presenting the top Romanian theatre: "Like a mirror of the best things of Romanian scene, Scena.ro magazine opens up in its fifth issue, the doors of RNTF 2009 and presents the best productions of the past season, foreign guests, books, conferences and movies that complete the program of a nine days theatre marathon, between 31st of October and 8th November. You may find its leading-figures on the stage or outside it, on the screens or in bookshops, but, no matter where are they, you can be sure they have something in common: all of them are among the creators of a "living theatre», the kind that deserves to have a place in our lives."

E un moment festiv pentru Scena.ro, care se năştea sub formă de ediţie - pilot cu exact un an în urmă, la ediţia a 18-a a Festivalului Naţional de Teatru. Dar sărim prilejul de a deveni patetici şi, odată marcat momentul prin aceste simple cuvinte, tragem aer în piept şi mergem mai departe. A continua acest proiect, a-I dezvolta, a-I îmbunătăţi permanent, ţinând cont de observaţiile celor care au devenit deja cititori pasionaţi ai revistei, ni se par singurele căi juste de a ţine vie această idee.

Asta e valabil şi pentru memoria unei personalităţi, precum şi pentru opera sa. Si mă refer acum la lonesco, de la a cărui naştere se împlinesc 100 de ani în 2009. Mai impresionant decât acest număr este numai cât de vie rămâne opera celebrului dramaturg astăzi, într-un alt secol, într-un alt context istoric, „pe altă planetă", cum s-ar spune. Toată lumea ştie că Eugene lonesco a făcut prin piesele lui paşi esenţiali într-un teritoriu ce avea să fie definit mai târziu drept „teatrul absurdului" şi a reuşit să intre în conştiinţa teatrală universală odată cu această sintagmă. Dar conceptul a fost lansat într-un volum în care lonesco ocupa un loc esenţial - „Teatrul absurdului" de Martin Esslin, netradus în limba română, deşi prima ediţie datează din 1961. Fragmente din acest volum apar în numărul de faţă al Scena.ro în premieră în limba română, iar volumul întreg, tradus de Alina Nelega, e parte din Colecţia FNT, editată împreună cu Unitext - editura UNITER. Nu e singura carte de pe raftul cu traduceri de referinţă pe care această colecţie îşi propune să-I completeze. Găsiţi în numărul de faţă şi fragmente din "Teatrul postdramatic" de H.T. Lehmann, în traducerea lui Victor Scoradeţ, precum şi un interviu cu Richard Schechner ce prefaţează apariţia volumului "Performance. Introducere şi teorie" de Richard Schechner, tradus de loana leronim. Si aceste două cărţi urmează să fie lansate în FNT 2009.

Revenind la lonesco, odată trecută această sută de ani, e momentul aici şi acum să punem din nou în discuţie o chestiune întotdeauna dureroasă pentru o cultură mică. Citind articolul Alinei Nelega, „Eugen lonescu - scriitor român minor", te întrebi o dată în plus dacă îl merităm cu adevărat pe lonesco, iar dacă mai punem la socoteală şi recenta dezbatere care a însoţit pe forumurile ziarelor ştirea despre Premiul Nobel revenit Hertei Müller, atunci chestiunea merită redeschisă. Comentariile forumiştilor nu se refereau la opera scriitoarei, ci numai la locul naşterii ei, rezultatul fiind că Müller era declarată „bănăţeancă", iar "miticii de la Bucureşti" erau somaţi să nu se declare compatrioţi cu ea. Din păcate, „mitici” sau bănăţeni, ne recunoaştem cu toţii în opera Hertei Müller, suntem cu toţii însemnaţi în adâncul nostru de urmările Răului pe care ea îl denunţă, iar asta ar trebui să ne preocupe mai mult decât chestiunile de suprafaţă. La fel ca în cazul lui lonesco, despre care a fost purtată o discuţie similară într-un ziar central în această vară.

Am încercat să strângem în numărul dedicat celei de a 19 - a ediţii

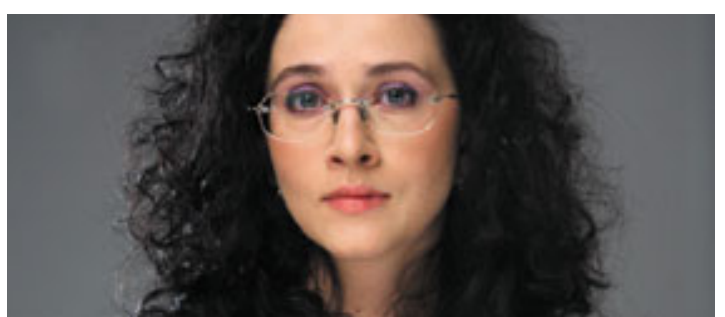

\section{Cristina MODREANU}

\section{Teatrul}
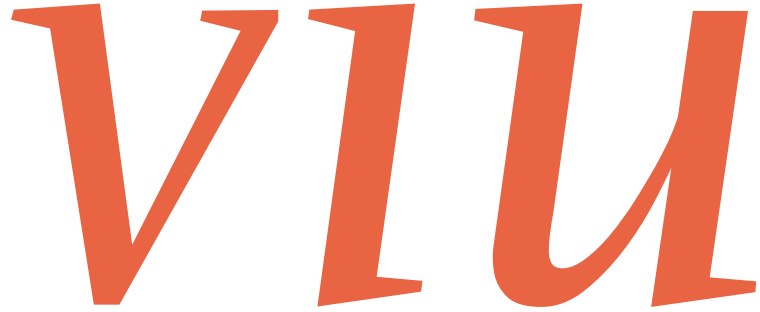

a FNT intervenţii despre toate acele spectacole invitate anul acesta şi care nu au fost încă discutate în numerele anterioare ale Scena.ro, fiindcă ambiţia revistei este aceea de a vorbi, într-un fel sau altul - prin cronici, inteviuri, eseuri - numai despre producţiile şi evenimentele teatrale cu adevărat reprezentative pentru teatrul românesc. Aşa cum FNT este platforma de prezentare a celor mai bune producții româneşti, iar scopul Showcase-ului, modulul principal al evenimentului, este acela de a aduce la București programatorii internaţ̧ionali care pot repune în circulaţie internaţională valorile teatrale româneşti. Sprijinul Institutului Cultural Român a fost în acest an esenţial pentru ca acest schimb să poată avea loc. Celălalt scop al festivalului este să refacă legăturile teatrului românesc cu teatrul lumii, segment reprezentat anul acesta mai puţin prin "spectacole vii" - singura companie din străinătate prezintă spectacolul „Cântăreaţa cheală" de Eugène
Ionesco, în regia lui Jean-Luc Lagarce în deschiderea FNT pe 31 octombrie - dar intens prin conferințe - Richard Schechner şi Aleks Sierz vor fi la Bucureşti - şi prin numeroasele filme despre personalităţi din teatrul lumii care vor fi proiectate în nocturnă la cinematograful "Elvira Popescu" de la Institutul Francez.

Ca o oglindă a scenei româneşti cu ce are ea mai bun, Scena.ro deschide în acest număr al ei, al 5-lea, uşile FNT 2009 şi vă prezintă cele mai bune spectacole din stagiunea trecută, cărţile, conferinţele şi filmele care completează programul celor 9 zile de maraton teatral desfăşurat între 31 octombrie şi 8 noiembrie, invitându-vă la cel mai important eveniment al anului teatral. Fie că îi veţi găsi pe scenă sau în afara ei, pe ecrane sau în librării, cei despre care vă vorbim au ceva în comun: sunt creatorii unui "teatru viu”, căruia merită să-i facem loc în viaţa noastră. 


\section{Sumar}

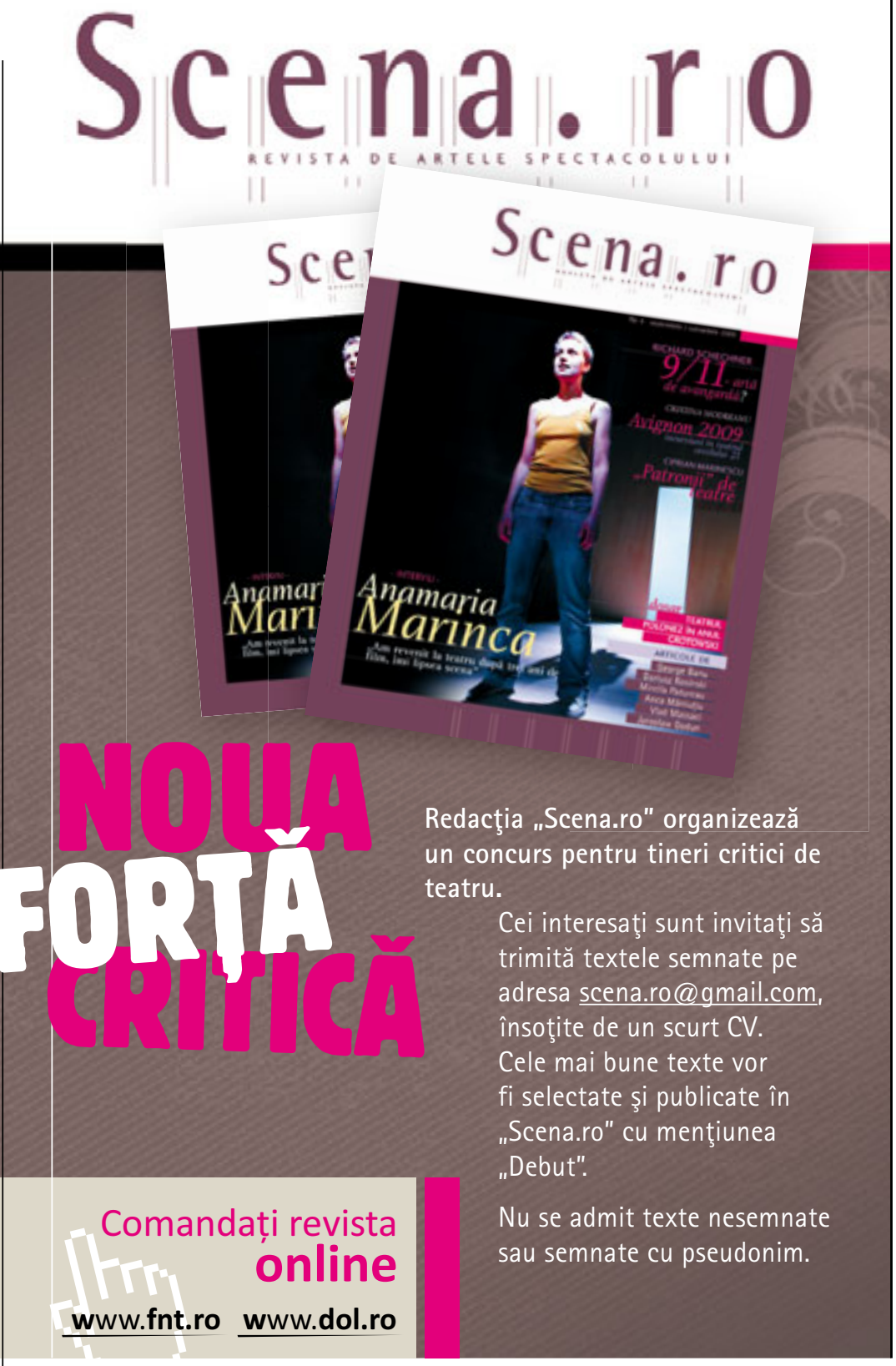

\section{INTERVIU -}

3 Mariana Mihuţ - „Lear e unul dintre puţinele roluri...”

5 Tompa Gábor - „Îmi plac textele cu structuri muzicale..."

8 Mihai Măniuţiu - Revoluţia antropofagă

10 Richard Schechner - „Facem interviul, suntem..."

\section{CRONICA -}

12 "Turandot", regia Andryi Zholdak

13 „Lucia patinează", regia Radu Afrim

14 "Krum", regia Theodor-Cristian Popescu

17 „Frumos", regia Vlad Massaci

19 "Cântăreaţa cheală", regia Alexandru Dabija

20 "poimâine, alaltăieri", regia Gianina Cărbunariu

21 "Trei surori”, regia Ada Lupu

22 "Lapte negru", regia Claudiu Goga

23 "Povestea de iarnă", regia Alexander Hausvater

24 "Sinucigaşul", regia Felix Alexa

25 "Faceţi loc", regia David Schwartz, „Hipioţi şi bolşevici”,

25 regia Felix Crainicu

26 „pool (no water)”, „Concreţii", regia Alexandru Mihăescu

27 „România! Te pup." regia David Schwartz

\section{OPERA REVIVAL -}

28 "Macbeth", regia Petrică lonescu,

28 "Otello", regia Mihai Măniuţiu

"Orfeu şi Euridice", regia Alexandru Darie,

29 "Evgheni Oneghin", regia Ion Caramitru, "Simfonia fantastică", regia Gigi Căciuleanu

\section{RUBRICl -}

30 Mihaela Michailov - Corpul convenţiei

31 Alina Nelega - Eugen lonescu, scriitor român minor

32 Mirella Patureau - Turandot, ca un vis nebun

\section{IN / OUT -}

34 Mirella Patureau - Cântăreaţa cheală, ierişi azi

37 Iulia David-Omul-performance

38 Cristina Modreanu - Conserve de imagini...

\section{ESEU -}

40 Martin Esslin - Eugène lonesco, teatru şi antiteatru

42 Hans-Thies Lehmann - Despre Robert Wilson

46 Anca Măniuțiu - Paradoxul polonez II

\section{VOICE OVER - articole de}

48 Cristian Tudor Popescu - Imaginea 3D şi omul 2D

50 Alexandra Badea - Un puzzle incomplet

\section{REWIND -}

53 Florentina Bratfanof - Top 3 magicieni

55 In memoriam lon Cojar

\section{Distribuită prin intermediul partenerilor noştri:}

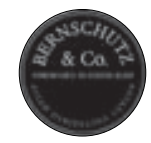

Ceainăria

Bernschutz

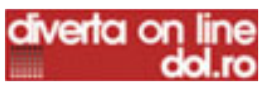

Diverta online

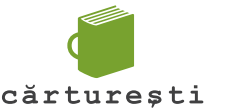

\section{Librăriile}

Cărtureşti

\section{Scena.ro}

Revistă editată cu sprijinul

Uniunii Teatrale din România (UNITER)

\section{Redactor-şef CRISTINA MODREANU}

Colegiu de redacție

Magdalena Boiangiu, Iulia Popovici, Anca Rotescu,

Ciprian Marinescu (secretar de redacţie), Ionuţ Sociu

PR şi traducere în lb. engleză

Florentina Bratfanof

Concepție grafică

Antal Szilárd
Distributia şi comenzi

Florentina Bratfanof - 0722529446

Coperta I: Foto din spectacolul "Lear" regia: Andrei Şerban, foto: Bulandra

Tipar: $\quad$ EQUUS DESIGN, Bucureşti

Scena.ro ISSN 2065 - 0248 



\section{Regizorul TOMPA Gábor "Îmi plac textele cu structuri muzicale, teatrul absurd, clasicii"}

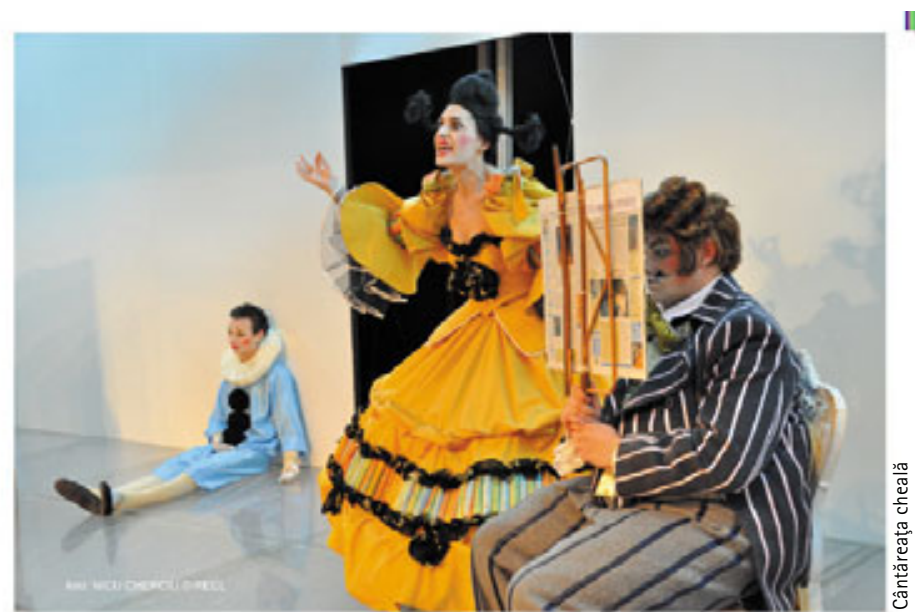

Una din principalele sarcini pe care vi le-aţi propus ca director este reîmprospătarea permanentă a trupei. De vreun an însă, Ministerul Culturii blochează toate posturile care se eliberează în teatre. Credeţi că s-a terminat astfel şi cu principiul reîmprospătării prin angajare?

Interesant cât va mai ţine şi asta. Există deja funcţionari ai crizei economice, care o folosesc ca pretext pentru a nu mai face nimic în privinţa legii teatrale. După părerea mea, întrebarea are două tăişuri. Sigur că, din 1993 încoace, când a absolvit şi Bogdan Zsolt, i-am adus aici, an de an, pe cei pe care i-am considerat mai talentaţi. Am
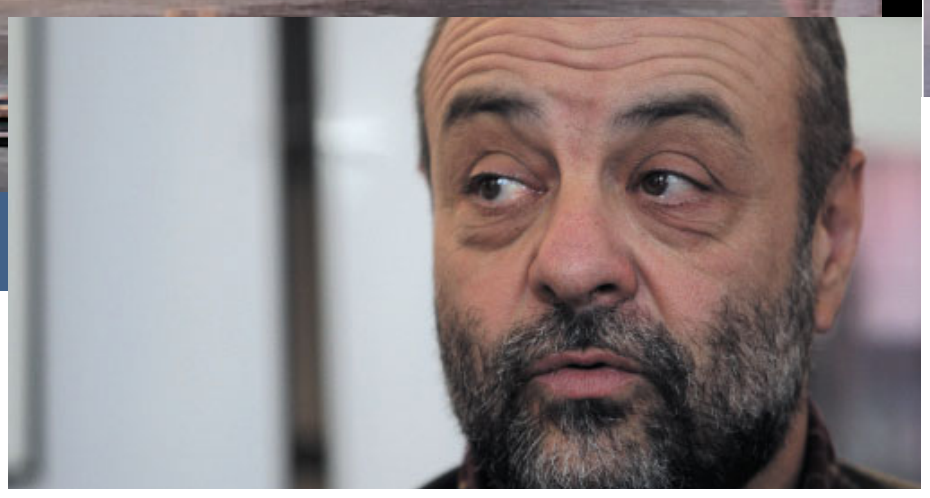

Un interviu realizat de Ciprian MARINESCU

reuşit să dublez numărul de posturi, fiindcă aveam nevoie de actori pentru cele două săli, pentru a face spectacole în paralel şi pentru a merge în turnee. Însă chiar şi fără blocarea posturilor, oricum $\mathrm{m}$-aş fi oprit cu angajările anul acesta, pentru că învăţământul artistic de limbă maghiară a ajuns la un procentaj negativ în ce priveşte balansul dintre profesorii buni şi cei incompetenţi, atât la Cluj cât şi la Târgu Mureş. Câtă vreme anumiți profesori continuă să perpetueze lipsa de competență și de profesionalism în teatru, eu refuz să mai angajez absolvenţi. Şi nu pot să nu mă gândesc în cazul acesta că la Academia de Teatru din Budapesta, studenţii au făcut revoluție din cauza unui rector incompetent. Este imposibil ca un profesor de teatru care a absolvit actoria să nu fi jucat niciodată, sau unul care a terminat regia să nu fi montat vreodată. Studenţii de care vorbesc nu s-au mai dus la cursuri până nu s-au schimbat lucrurile. Aceasta este o uşoară sugestie din partea mea. Din interior, studenții sunt în măsură să revoluţioneze un învăţământ artistic Dumneavoastră aţi predat aici, la Cluj...

Am predat la ambele academii de limbă maghiară din România. La Târgu Mureș am predat regie la clasa în care erau László Bocsárdi, Olga 


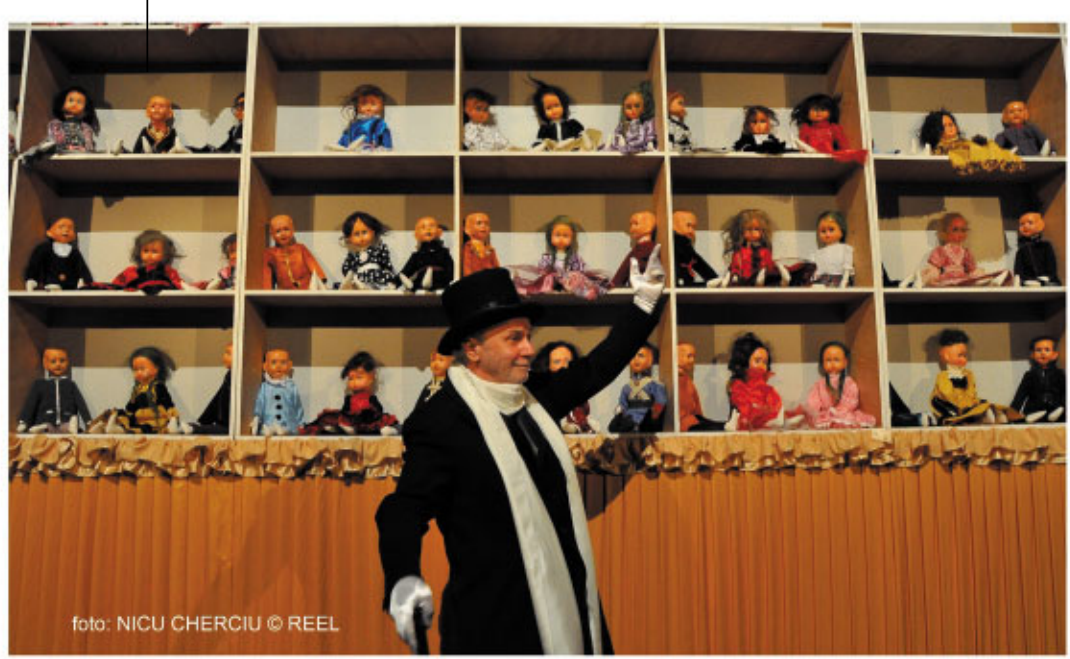

\section{Interview with Tompa Gabor 11}

The second part of the interview realized by Ciprian
Marinescu with director Tompa Gabor, highlights
the low level of directing schools in Romania, but
also tells the positive stories of his experiences in
Romanian theatre schools. Tompa Gabor reminds us
the way famous Romanian directors work with their
actors: Lucian Pintilie is "a total dictator", Ciulei is
nicer, but exigent," and finally "Silviu Purcarete creates
images that make the line between a good actors and
a mediocre one dissapear. This is why Vlad Mugur used
to say in admiration that Purcarete can make shows
even without actors". Tompa Gabor, a famous director
himself, speaks about his interest for texts defined by
inner musicality which one can find either in classic
works, either in the absurd theatre.
Barabás, Istvan Kevesdi - probabil cea mai reuşită generație de studenţi - şi organizam admiterea şi disciplinele. Acolo urmau să predea cei mai buni profesori din ţară şi din străinătate. Dar asta a funcţionat numai vreo 2-3 ani, după care lucrurile au început să meargă pe bandă rulantă. În momentul în care catedra devine mai importantă decât studentul, învăţământul se degradează. În anul acela, după aproape patru decenii, redemarase învăţământul de regie în limba maghiară. Erau 45 de candidaţi pe cinci locuri şi, cu toate acestea, nu am putut să le acoperim. Am găsit doar patru tineri capabili să devină regizori, eu nefiind de acord să umplem locurile cu orice preţ. Anul următor au vrut să organizeze din nou concurs, iar eu am spus „stop!". Dacă după patru decenii, din 45 de candidaţi, nu am putut lua decât 4, mi se pare fără rost să organizăm admiteri în fiecare an. Totuşi, au zis că şcoala ar fi în pericol de a nu mai fi acreditată, sau că învăţământul ar putea fi întrerupt aşa că s-a făcut concurs. Au venit 13 candidaţi, din care au fost admişi un băiat şi două fete. Băiatul a plecat peste un an, iar eu am rămas să le predau acelor două fete care erau fără speranţă... Aşa că m-am retras. $\mathrm{N}$-avea rost să iau un salariu pentru a pregăti nişte tineri fără aptitudini regizorale. Retrăgându-mă de acolo, am contribuit la înfiinţarea secției maghiare de teatru de aici, de la Cluj. Mă gândeam că se va crea o alternativă la şcoala din Tg. Mureș, şi că nu vom înscrie studenţi în fiecare an - căci gândiţi-vă ce am face peste zece ani cu o sută de dramaturgi şi tot atâţia teatrologi sau regizori?! Noi nu suntem Rusia, America sau China, suntem totuşi o cultură mai mică. Din păcate, ideea mea nu a fost respectată. Încă de la început au apărut profesori care, moral sau pedagogic, nu aveau ce căuta în învăţământul teatral. Ei continuă să fie angajaţi direct din şcoală, fără să ateste calităţi de actori, de teatrologi sau de regizori. Pe mine mă fascinează şi mă pasionează învățământul de regie. E unul din motivele pentru care am şi acceptat să predau la University of California, San Diego.

La ce anume sunteţi atent atunci când examinaţi un posibil student? Cum vă daţi seama că este sau nu este făcut pentru regie?

E un lucru foarte delicat. Greşeala este iminentă, trebuie să ne-o asumăm, fiindcă nu putem fi total obiectivi. Desigur că pornim de la creativitatea fiecărui individ, de la capacitatea lui de a crea o lume de obiecte, de situaţii, imagini şi poveşti scenice. E vorba de o creativitate specifică care trebuie sesizată şi încurajată să se dezvolte, până când fiecare student îşi găsește propria sa voce. În interiorul operei unui regizor, fiecare spectacol se abordează altfel, fiecare proces de repetiţie îşi dictează singur metodele, conform nimicului care este necesar în creaţie. Trebuie să ţinteşti nimicul, pentru că lumea însăşi s-a creat din nimic. Cine crede în artă crede şi în creaţie, deşi există lucruri ştiute şi lucruri care trebuie uitate, aşa cum trebuie să existe un echilibru între ordine şi haos. Există probe de aptitudini, care pot fi subiective. Să faci o poveste dintr-o fotografie, dintr-o pictură cunoscută sau dintr-un anunţ publicitar, să creezi poveşti din cuvinte, să repeţi un subiect, 0 scenă din o piesă, să discuţi concepţii, gânduri. Eu sunt unul dintre cei care cred că regia se poate învăţa, în sensul că orizontul de cunoaştere se poate lărgi. Însă, de pildă, lucrul cu actorul este ceva ce se poate şi în acelaşi timp nu se poate învăţa. Stanislavski, întrebat ce trebuie să ştie un regizor, a spus: „Totul!". Sunt lucruri ce ţin de psihologia umană care nu se pot preda. Lucian Pintilie, care este un dictator desăvârşit, scotea din actori tot ce se putea, Ciulei e mult mai amabil, mai drăguţ, dar e foarte exigent. Silviu Purcărete ştie să creeze imagini în care graniţa dintre actorul bun şi actorul mediocru dispare, în sensul bun al cuvântului. Am văzut spectacole în regia lui aproape de a fi capodopere, dar în care actorii erau mediocri. Vlad Mugur spunea, cu sens admirativ, că Purcărete poate să facă spectacole şi fără actori. Eu nu pot! Observ că şi în teatrul dumneavoastră e din nou „la modă” Cehov. De ce „Unchiul Vanea”, de ce „Trei surori”, la o distanţă atât de scurtă unul faţă de celălalt?

Probabil că Cehov va fi „la modă" mereu. Eu nu mai montasem Cehov înainte. În cazul meu există mai multe explicaţii. În şcoală am dat examen din "Trei surori”, actul patru. Apoi a venit momentul 1985, când Gyorgy Harag a făcut „Livada de vişini" şi în ultimele sale zile m-a rugat să continuu repetiţ̧iile în locul lui, pentru că nu mai putea, era bolnav. Eu făceam un spectacol, aici, la Cluj, dar am întrerupt repetiţiile ca să merg să pun luminile în decorul lui. Acel spectacoltestament $m$-a marcat aşa de tare, încât nu am mai putut să montez Cehov 20 de ani de atunci. Nu am mai vrut. Dar între timp s-a mai făcut Cehov la Teatrul Maghiar. Am avut un „Ivanov" mai puţin reuşit, dar şi o "Livadă de vişini" într-o realizare extraordinară a lui Vlad Mugur, apoi acest binecuvântat "Unchiul Vania" al lui Andrei Şerban. În "Trei surori" montat de mine am suprapus două motive care m-au interesat dintotdeauna: muzicalitatea şi grotescul teatrului absurd - de fapt, ale absurdului în general, fiindcă nu teatrul este absurd, ci lumea. Autori precum lonesco, Beckett şi Caragiale - ca predecesor al lui lonesco - mă interesează atât pentru limbajul lor, cât şi pentru structura lor muzicală. "Cântăreaţa cheală", de pildă, are o precizie de ordin muzical, fiind compusă din replici pline de non-sens, din care însă nu poţi tăia nici una. E ca şi cum ai sări note întregi dintr-o simfonie. La fel e şi în „Aşteptându-I pe Godot”... Mă interesează limbajul, structura muzicală, precum şi motivul intervenţiei divine, al mântuirii, al faptului că omenirea nu poate ieşi din această nevoie stupidă de a avea idoli. În „Trei surori” idolul lui Prozorov, tatăl, este înlocuit. Deşi se creează un vacuum, un mic moment de libertate care ar putea fi o opţiune, nimeni nu ia în calcul acest lucru. Se face înlocuirea unui idol cu un alt idol - cel al Nataşei, al subculturii care începe să domine lumea noastră. Sigur că sunt şi alte lucruri interesante în aceste două spectacole după Cehov, ca de exemplu întrepătrunderea dramatică şi frumoasă dintre text şi referinţele personale ale actorilor. Probabil că din cauza acestor suprapuneri de destine dintre personaje şi actori ele par atât de puternice. 

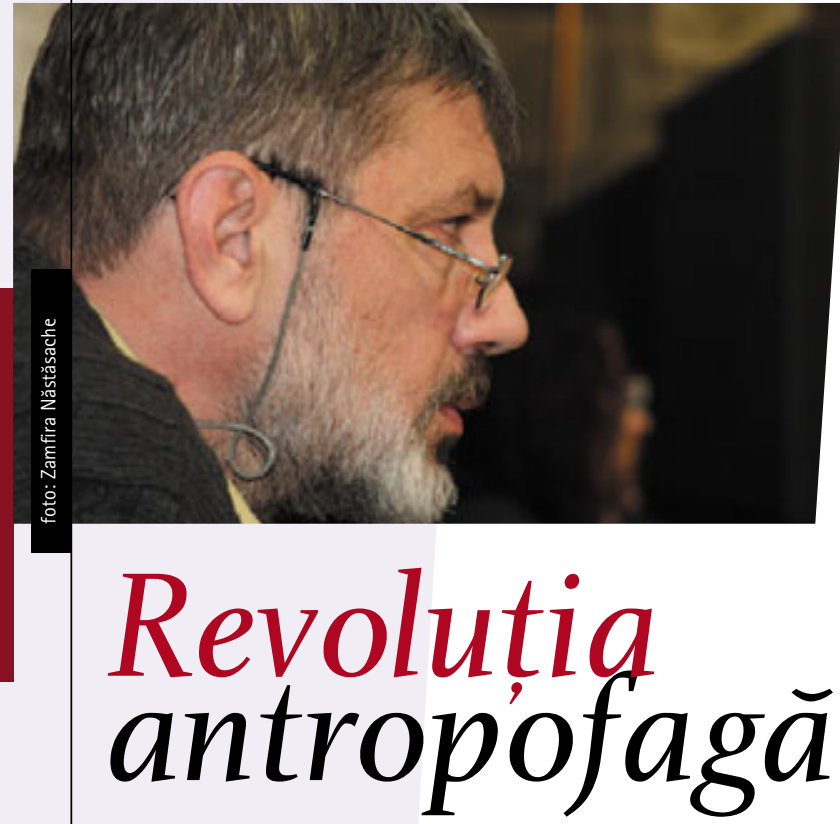

\section{Un interviu de András VISKY cu regizorul Mihai MĂNIUȚIU}

Büchner scrie această piesă despre Revoluţia Franceză la vârsta de 22 de ani, iar Danton nu are încă 35 de ani când este executat. „Moartea lui Danton” este aşadar o piesă a revoluţiei care presupune o vârstă anume - primăvara vârstei. În distribuţia ta - decizie absolut conştientă - nu te referi la această vârstă a tinereții, a primăverii, ci optezi pentru o privire a fenomenului revoluţionar din unghiul unor personaje care au nu numai forţa, ci şi înţelepciunea acţiunii chibzuite şi poate chiar lente.

Excesul de sânge şi de moarte aduc cu sine îmbătrânirea prematură. Personajele sunt tineri deja bătrâni. E ca şi cum ar fi trăit deja cel puţin cincizeci de ani. Au trecut prin războaie, prin comploturi, au făptuit crime. Toţi, sub o formă sau alta, au participat la ceea ce azi am numi o crimă de război.

Şi media de vârstă era mai scăzută în perioada respectivă. lar invenţia lor, teroarea politică, i-a îmbătrânit pe toţi. Tribunalul Revoluţionar a fost un mecanism de apărare a Revoluţiei, dar s-a transformat după aceea în Dumnezeul Revoluţiei. Dintr-un simplu mecanism a devenit o forţă omnipotentă, şi nu a mai putut fi oprită; a început de fapt să-i înghită pe toţi. Mecanismul acesta ipostaziat în Dumnezeu, în adevărata deitate a revoluției, a fost ghilotina. În perioada Revoluției franceze aveau loc numeroase jocuri și sărbători care inventau cu frenezie deităţi. Revoluţionarii se lipseau de Dumnezeu, dar nu de deitate. În spatele lor, în umbră, a crescut această monstruoasă deitate, ghilotina, acest mecanism al Tribunalului Revoluţionar, pe care Stalin nu a mai fost nevoit să-I inventeze, pentru că era gata inventat. A trebuit doar să-I repună în funcţiune: teroarea de stat. Revoluţionarii precum Danton sunt de fapt inventatorii terorii de stat, în care proprii cetăţeni sunt consideraţi principalii duşmani, duşmanii dinăuntru - mai duşmani decât duşmanii externi. Teroarea politică este cea care i-a îmbătrânit. În acelaşi timp, genialitatea lui Büchner adaugă la vârsta naturală a eroilor această „vârstă a înţelepciunii textului". Se întâmplă exact ca la Shakespeare, unde şi portarul castelului are replici de geniu. Vârsta naturală a actorilor e fidelă textului şi modului cum resimţim noi astăzi Revoluţia. „Moartea lui Danton” este un spectacol pentru azi şi despre azi. Şi despre cum simţim şi resimţim noi toate lucrurile care şi-au avut sursa în Revoluţia Franceză. Teroarea de stat, statul 
ipostaziat în deitate punitivă, represivă, nu este ceva care a dispărut; el supravieţuieşte, mascat, chiar şi în democraţii. Privind prin grila Revoluţiei Franceze, putem vedea mult mai clar care este cu adevărat situaţia noastră în lume şi în stat.

Există un dialog subtil între „Wozyeck” şi „Moartea Lui Danton". Mă refer şi la spectacol, nu numai la modul de abordare a textului, şi anume transformarea acestei partituri, sau mai degrabă crearea unei partituri care transformă textul lui Büchner într-o parabolă. Mie mi s-a părut că spectacolul tău „Woyzeck” este o parabolă; iar „Moartea lui Danton” devine o parabolă a revoluţiei, sau o parabolă a confruntării umanului cu maşinăria impersonală a istoriei, ba mai mult, a terorii. Cum se explică faptul că atenţia ta se îndreaptă în mod obsedant asupra acestui aspect, atât în montările tale Büchner, dar şi în cele care se bazează pe tragedia antică? În viaţă suntem cu toţii confruntaţi în mod fundamental cu două lucruri. Cu toţii vrem să ne realizăm individual. Pentru unii asta înseamnă căutarea fericirii, pentru alţii căutarea iubirii ori a bogăţiei, pentru alţii căutarea gloriei militare, literare ş.a.m.d. Toate aceste dorinţe se izbesc de barierele fireşti construite de societate, şi de barierele nefireşti impuse de societate atunci când ea se constituie într-un aparat totalitar. În „Woyzeck" avem un aparat opresiv militar, în "Moartea lui Danton" - un aparat totalitar revoluţionar. Şi noi, cei din România, am fost confruntaţi multă vreme cu aparatul militaro-securisto-statal de tip totalitar; eu mi-am petrecut cea mai mare parte din viaţă încercând să supravieţuiesc acestui aparat. Pe de o parte, aşadar, este acest aspect, şi, pe de altă parte, când nutreşti visul relizării personale, ajungi oricum, mai devreme sau mai târziu, să te confrunți cu moartea. În ciuda oricărei realizări, nu vei putea fi ce ai devenit sau să păstrezi ce ai din pricina morţii, şi atunci al doilea aspect fundamental este confruntarea cu moartea, este confruntarea cu „Există ceva dincolo?", „Ce fac aici ca să exist şi dincolo?", sau: „Nu-mi pasă de dincolo, pentru că nu există dincolo, şi totul e aici" - iată cele două atitudini tranşante. Büchner vorbeşte cu mare intensitate despre asta. În "Woyzeck" e ca şi cum totul ar fi aici. Totul se joacă aici, fără dincolo, chiar dacă, la un moment dat, Marie rosteşte o rugăciune lipsită de speranţă... Toate celelalte personaje există într-un orizont fără dincolo. Totul este aici, fără Dumnezeu. În timp ce, paradoxal, tocmai într-o piesă a marelui joc al istoriei, moartea este un orizont care provoacă continuu, sub o formă sau alta, raportul cu acest "dincolo". Acest dincolo e pentru unul sau două personaje Dumnezeu, iar pentru majoritate: posteritatea. E fascinant cum personajele încearcă să-şi construiască imaginea legendară, imaginea de după moarte... ca pe un fel de Dumnezeu al lor personal. În „Moartea lui Danton" e mult mai prezentă decât în „Woyzeck" ideea, obsesia "Ce e dincolo? Există sau nu există Dumnezeu?". Spectacolul tău este montat în cutia neagră a scenei, iar în această cutie neagră mai este construită încă o cuşcă metalică, în interiorul căreia se joacă o bună parte din timp. Noi, spectatorii, privim acest experiment infernal „din afară”, ceea ce iarăşi accentuează compoziţia de structură parabolică a spectacolului. Ba, mai mult, avem şi erinii, corul acesta al femeilor, care în mitologia greacă reprezintă dreptatea divină, dar şi conştiinţa noastră care ne urmăreşte peste tot. Văzând modul în care corul erinilor este prezent în acest spectacol, mă gândeam să te întreb dacă, după părerea ta, ar exista vreo remuşcare latentă şi pustiitoare în cultura europeană în legătură cu naşterea terorii?

În conştiinţa eroilor lui Büchner, ea există, cu siguranţă. Remuşcarea inspiră o scenă foarte importantă, scena crizei de conştiinţă a lui Danton („Eu sunt maestrul marii terori, iartă-mă, Doamne, pentru ce am făcut!"); ajunşi în închisoare, artizanii Marii Terori spun: noi suntem autorii acestei închisori, toate ororile care se întâmplă în momentul acesta în jurul nostru poartă semnătura noastră... noi suntem creatorii acestei capcane, am ajuns în interiorul creaţiei noastre, creaţia noastră este un infern, este o puşcărie. Büchner este foarte clar în privinţa asta. Ai spus foarte bine de senzaţia că

privim într-o carceră şi că decorul sugerează acest spaţiu închis. Sunt câteva momente în care carcera dispare, dar întotdeauna se revine la ea. Cei care creează sisteme carcerale - sugerează Büchner - vor fi, până la urmă, înghiţiţ̧i de ele. Prin urmare, în conştiinţa eroilor lui Büchner remuşcarea e foarte vie, şi cred că Europa, săraca, are şi ea foarte multe remuşcări - şi de tipul acesta, şi coloniale ş.a.m.d., dar nu aş da deloc acum cu pumnul în Europa, pentru că, spre deosebire de alte continente, şi-a cam recunoscut erorile, poate târziu, dar încearcă să recupereze. Eu cred că problema europeană e cu totul alta, şi anume că nu-şi mai recunoaşte cu adevărat originile. Cred că Europa - mie îmi place Europa!

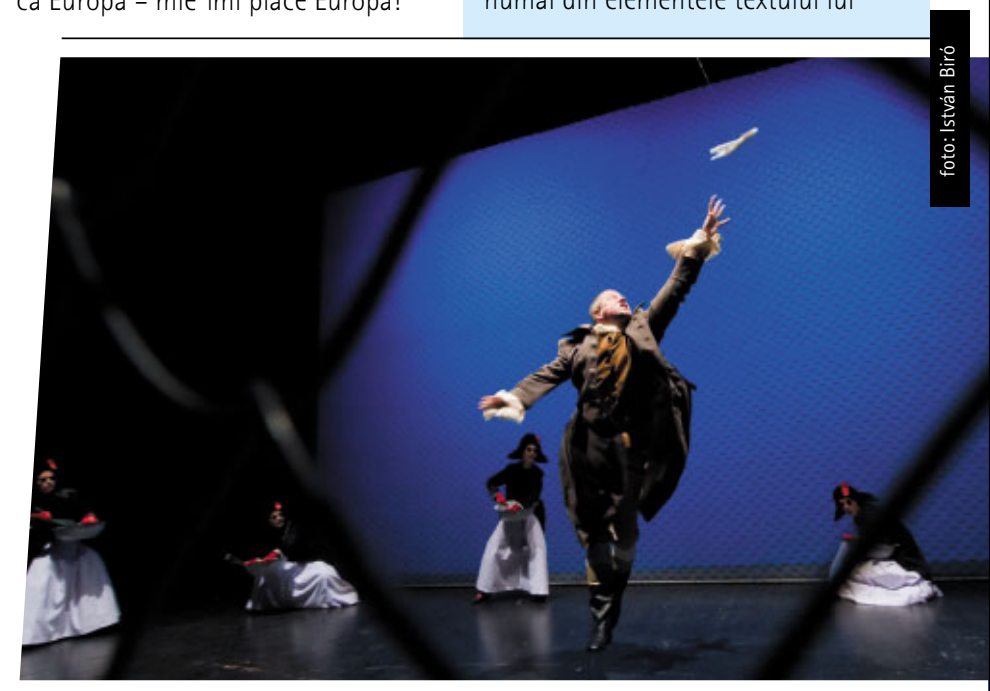

Büchner, neaducând elemente străine. În acelaşi timp, mi-aş dori un spectator pe care spectacolul să-। tulbure în aşa măsură încât lucruri care i s-au părut obişnuite, normale... să nu i se mai pară obişnuite. Adică: da, ne-am obişnuit cu toţii să fim liberi. Sigur, întotdeauna există limite, şi de fapt trebuie să existe limite, pentru că libertatea fără limite e cea mai cumplită încătuşare. Oameni care zic "E normal, ce ne pasă nouă de libertate?", să se trezească şi să regândească puţ̧in valoarea libertăţii. Pentru că văd şi pe stradă oameni care spun, sub diferite forme: „Nu libertatea e problema noastră". Nu, nu e problema noastră, pentru că suntem liberi. Dar libertatea e continuu ameninţată. Deci cei care se trezesc şi spun, „Da, libertatea este o mare valoare şi este ameninţată, să mă trezesc, să fiu atent, vigilent, pentru că nimic din ce e bine nu este definitiv achiziţionat." - constituie pentru mine publicul visat, publicul de predilecţie.
- trebuie să rămână cum a fost în anii cei mai buni de democraţie, dar această democraţie să nu fie atât de permisivă, încât să permită distrugerea, sub forme bizare, a democraţiilor europene. (...)

Care este spectatorul ideal pentru acest tip de spectacol?

Nu ştiu dacă există spectator ideal, deoarece deja am învăţat (şi asta-i foarte bine!) că spectatorii cu adevărat buni vor vedea un alt spectacol decât văd eu, privindu-mi spectacolul... Spectatorul ideal este cel care nu va vedea ce am gândit eu, cu exactitate, dar care nu-şi va compune viziunea despre spectacol din elemente exterioare acestuia. La fel cum am compus eu scenariul numai din elementele textului lui

\section{Antropofague Revolution}

$A$ ndrás Visky and director AMihai Măniuţiu are talking about "Danton's Death" by Georg Büchner, a production of Hungarian State Theatre from Cluj, and they focus on politics, history, French Revolution etc. On this occasion Mihai Măniuţiu states that "Danton's Death" is a show for today and about today's world. And it is about how do we feel about State terror, first imposed by the French Revolution. We thus can see better what is our situation today, what are our relations with the State." Director Mihai Măniuţiu believes that people should think twice about the importance of freedom in their lives, and after 20 years from 1989 this is a very good moment to do so! 


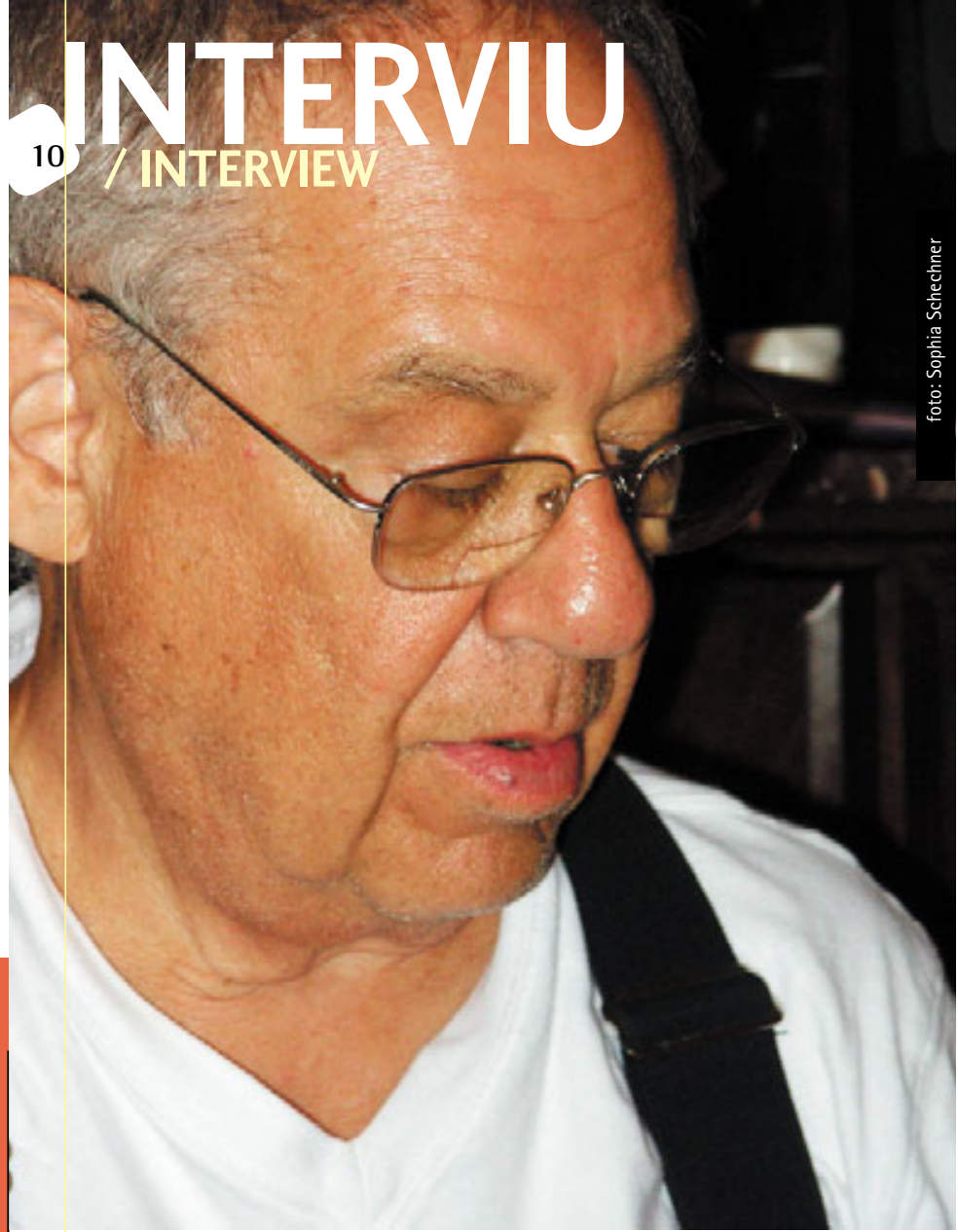

Eseurile lui Schechner vă vor purta pe varii meridiane, in interiorul unor culturi diverse, impresionându-vă cu siguranţă prin larga respiraţie intelectuală a ideilor, calitatea raţionamentelor, cantitatea informaţiilor şi mai ales amploarea/ originalitatea viziunii autoriale ancorate în precizia de bisturiu a argumentării.

Ca un preludiu (şi o încercare de sinteză/simplificare a conceptelor) pentru cititorii români mai puţin iniţiaţi în discursul academic, $m$ am întâlnit cu Richard la cafeneaua Lantern din West Village, cerându-i să facă anumite distincţii şi să clarifice nişte noţiuni, oferindu-vă posibilitatea să vă îmbarcaţi în călătoria teoretică schechneriană cu un minimum bagaj de cunoştinţe preliminare.

\title{
Richard SCHECHNER
}

\author{
"Acum facem interviul \\ propriu-zis - suntem în plin \\ performance"

\section{Un interviu de Saviana STĂNESCU}

Cum ai defini „to perform” în

relație cu „to play” (a juca)?

Aş începe prin a spune că putem recunoaşte în viaţa noastră de zi cu zi faptul că jucăm multe roluri. De la Shakespeare ştim cu toţii că lumea e o scenă iar oamenii sunt actori, ne interpretăm (perform) propriile identităţi, rolurile profesionale sau domestice, ca toată lumea să înţeleagă - sau nu - ce se întâmplă cu noi. VIAŢA SOCIALĂ imită ARTA şi nu neapărat invers, învăţăm să ne jucăm rolurile zilnice prin a ne referi conştient câteodată, inconştient în general, la diferite modele din artă. Cu alte cuvinte, dacă simţim că nu cunoaştem adevărul despre noi înşine, jucăm "Oedip"; dacă simţim că dragostea poate cuceri totul dar n-are un final fericit, jucăm "Romeo şi Julieta"; dacă simţim că oamenii sunt cruzi unii cu alţii, jucăm probabil Strindberg; dacă simţim că avem un anume control asupra destinelor noastre, dar nu cu totul, şi avem o privire ironică asupra vieţii, îl imităm pe Brecht. Aceste lucruri apar într-o formă distilată la început, sunt sarea şi piperul operelor de artă; le învăţăm fără să ştim câteodată, e un proces de feedback ceea ce se-ntâmplă pe scene sau la mese și în dormitoare. Viața imită arta și arta imită viața. E o relaţie dinamică. Performance Studies explorează această relaţie dinamică, nu presupune dintru început că una e primară şi cealaltă secundară. Ambele sunt primare, sau ambele sunt secundare - una celeilalte.

Ce distincţii poţi face între performance şi spectacol?

Nu ştiu dacă pot face aşa o distincţie amplă... 0 întreagă societate poate fi văzută ca spectacol: un şef de stat care apare cu pompă în public, sau un circ. E ceva care pune accentul pe îmbrăcămintea vieţii sociale, e atunci când iţi porţi bijuteriile şi hainele cele mai bune ca să-i impresionezi vizual pe alţii. Vizibiltatea e un fenomen al distanţei. Te impresionează de la distanţă. Sunetul e mai dificil, operează la nivel local, iar dacă îl transformăm în semnale digitale, chiar şi mai aproape. Gustul, mirosul şi atingerea sunt şi mai apropiate. Aşa că spectacolul pune accentul pe ceea ce e incitant şi impresionant de la distanţă şi 


\section{Interview with Richard Schechner}

$T_{\text {hite }}^{\text {he }}$ he interview is a non-academic discussion involving terms like "performance" and "environmental theatre" that Richard Shechner has introduced in the world of theatre long ago and has developed in his essays since. In this interview drove by Saviana Stanescu who have worked with him in New York, Schechner, one of the most famous American directors and theoreticians, explains more about the difference between performance and theater and gives an inside look on the new book in RNTF collection - the first Romanian version of his work translated by loana leronim.

place ochiului. Sunetul - internalizat sau actual - poate fi şi distant, şi apropiat; când învăţăm să scriem, convertim sunete în semnale, luăm ceea ce oamenii spun şi transformăm în semnale electronice. Nu putem transporta mirosul, gustul, atingerea. Nu poţi atinge/mirosi/gusta un million de oameni în acelaşi timp, dar li te poţi arăta în acelaşi timp. Spectacolul place maselor, e mare, grandios. E vizual şi impresionează prin show extern.

\section{Care este relaţia dintre performance şi teatru?}

Performance e o categorie mai largă, teatrul una mai mică. Eu aparţin unei familii; care e relaţia lui Richard cu Schehnerii? Sunt mai multi Schechneri, dar Richard e doar unul. Sunt mai multe feluri de performance. Teatrul este un gen particular de performance, care în tradiţia vestică implică acel model aristotelian: caracterizare, fir narativ, prezenţa unui grup de oameni pentru delectarea altora. Sunt alte forme de performance care nu implică asta. Spre exemplu, când asculţi cântece pe iPod, asculţi un performance, dar nu unul teatral. Nu există un public - tu eşti publicul, se adresează urechilor tale şi nu văzului. E muzical, dar digitalizat. Apoi sunt şi acele roluri din viaţă care sunt performance-uri zilnice: performance-ul unui doctor, al unui profesor etc. Sau performance art, ceea ce face un artist vizual ca Marina Abramovic, sau ce făcea Allan Kaprow. Performance art se manifestă prin acţiune dar nu se subsumează unei structuri narative, deci nu se numeşte teatru pentru că n-are acel plot aristotelian - poveste, fir narativ.

Hans-Thies Lehmann a teoretizat existenţa unui teatru postdramatic. Unde îl plasezi în relaţie cu performance-ul? Teatrul post-dramatic este o frază pe care eu am inventat-o si Hans a luat-o şi a dus-o mai departe, imaginând o confluenţă între performance art, celelalte tipuri de performance (cel domestic, zilnic, spre exemplu) şi teatru. Tocmai am văzut în Lincoln Center Festival "Les Éphémères", în regia lui Mnouchine, un spectacol extraordinar, cu fire narative multiple, ca o soap opera adusă la un nivel artistic elevat. Într-un anume sens e post-dramatic, nu e doar o poveste ci o serie de poveşti nu neapărat legate una de alta. Sau spectacolele lui Richard Foreman, care nu au fir narativ. Deconstruirile de piese clasice ale Wooster Group intră în aceeaşi categorie, căci structura narativă nu este importantă. În acelaşi timp, toate sunt considerate teatru, au atributele teatrului: sunt prezentate în faţa unui public, sunt pregătite de un grup de profesionişti, au loc pe scenă, dar nu pun accentul pe firul narativ şi pe dezvoltarea personajelor.

\section{Ce s-a întâmplat cu teatrul ambiental (environmental} theatre)?

Teatrul ambiental - pe care I-am botezat şi teoretizat - e acum numit site-specific performance, în special pentru că „environmental" e un cuvânt care a migrat înspre ecologic, acela fiind intelesul lui primar acum. Eu l-am folosit în sensul dat în pictură, anume de a crea un întreg spaţiu. Kapprow vorbea despre colaj şi mediu/ambient şi eu am adaptat formula pentru teatru. Deşi acum există acest teatru în situ (site-specific), iar performance art e în general site-specific, teatrul „ortodox" în care există o separare între scenă şi public, actori şi spectatori, e încă forma dominantă de prezentare teatrală. Nu-mi place asta, cred că e retrograd, cred că e o ruşine, şi nici nu-mi place acest tip de teatru foarte mult. Mă plictisesc, adorm în general, dar asta $e_{\text {, }}$ acest teatru există. Nu există explicaţii pentru prostul gust...

\section{Care este relaţia dintre}

performance, avangardă şi

performance art? Dar dintre

performance şi antropologie?

În ceea ce priveşte avangarda, am explicat pe larg care e situaţia în eseul meu "5 avangarde sau nici una" publicat în această carte*. Antropologia, în sens larg, este studiul comportamentului uman la nivelul culturii din care face parte. $\mathrm{Nu}$ la cel al psihologiei umane, ci relaţia dintre acţiunile umane mici, individuale, şi societate/cultură. Performance-ul şi teatrul se ocupă tot cu asta în esenţă. Subiectele din teatru şi performance art sunt culturi umane exprimate prin individualităţi artistice, interpretate în cadrul unor reţele sociale, re/prezentate în faţa unui grup de oameni.

În al doilea rând, comportamentul performativ e ritualizat. E repetitiv, se ocupă cu interpretarea unor anumite valori fundamentale. Metodele antropologiei sunt dezvoltate să înţeleagă aceste acţiuni ritualizate pătrunse în interiorul unei culturi. Nu spun că tot teatrul şi performance-ul se ocupă cu asta, dar o mare parte da. În lucrările mele teoretice, am operat la intersecţia dintre gândirea antropologică şi cea teatrală. Vedeţi cartea mea "Între Teatru și antropologie".

Încercările de definire a unor termeni sunt restrictive, ştim amândoi asta. Mă gândeam să schimbăm discuţia de la ce ESTE Performance Studies, la ce PERMITE artiştilor şi teoreticienilor să facă, să exploreze?

Nu numai că permite, încurajează, chiar cere, impune ca teoreticienii, lumea academică să se uite la întregul complex care creează un performance, ceea ce eu numesc secvenţa performativă totală: pregătirea/antrenamentul, workshopul, repetiţiile, încălzirea, performanceul propru zis, răcirea, urmările, chiar şi evenimentele sociale din jurul lui. Spre exemplu, acest interviu, ce ar însemna pregătirea în cazul acesta: amândoi suntem şcoliţi în Performance Studies şi am studiat acest tip de discurs, workshop - nu prea avem aici repetiţie: da, tu ai adus nişte întrebări pe hârtie, scenariul, eu am adus reportofonul, m-am pregătit; ne-am încălzit bându-ne limonadele; acum facem interviul propriu-zis - suntem în plin performance; când se termină, închid reportofonul, ţi-I dau ţie, ne îmbrăţişăm şi ne zicem la revedere, eu mă duc în apartamentul meu etc. Urmările sunt că tu o să asculţi şi o să transcrii interviul, apoi o să-l intergrezi în prefaţa pe care o scrii la cartea mea. Putem ilumina orice întâlnire, orice eveniment, prin acest cadru teoretic. Acesta ar fi un exemplu din viaţa socială. În ceea ce priveşte un performance teatral, lucrurile se întâmplă la fel, performance-urile sunt modele ale vieţii sociale, şi viaţa socială e un model pentru performance. Orice performance trece prin această secvenţă. Artiştii fac la fel: se pregătesc, participă la workshop-uri, îşi îmbunătăţesc performanţele, repetă, joacă în spectacol/performance, iar urmările sunt cronicile, viaţa acelui spectacol.

\section{Care este viitorul Performance}

\section{Studies?}

Cred că dacă ne gândim prea mult la viitor e ca şi cum ne-am masturba: ai mari fantezii, dar nu se întamplă practic mare lucru. Viitorul e ceva care se întâmplă pur şi simplu, faci anumite planuri dar nu poţi fi sigur ce va urma. Bineînţeles că aş vrea să văd mai mulţi tineri care studiază acest domeniu şi sunt sigur că asta o să se întâmple pentru că noi pregătim mulţi specialişti la NYU şi în alte universităţi şi mulţi devin profesori la rândul lor. Dar prezentul e ceea ce contează. Sunt bucuros că o să apară această carte în România. Alte cărţi îmi apar în Slovacia, Lituania, China etc. Lucrările mele ajung să fie cunoscute peste tot şi asta e foarte bine. Sper că Performance Studies nu va pierde legătura cu zona artistică şi cea a vieţii de zi cu zi, că nu va fi prea încărcată teoretic. În acelaşi timp, sper că practica artistică nu va uita că se poate înţelege pe ea însăşi doar prin teorie.

* fragment din prefaţa volumului "Performance. Introducere şi teorie" de Richard Schechner, traducerea loana leronim, Colecţia FNT, editura UNITEXT 
"Prinţesa Turandot" după Carlo Gozzi, cu care Teatrul Naţional "Radu Stanca" din Sibiu şi-a deschis stagiunea 2009-2010, e un spectacol uşor atipic pentru controversatul regizor ucrainean Andryi Zholdak. Altfel spus, montarea înşeală aşteptările - întreţinute de istoricul de violenţă, agresivitate fizică şi psihică, nuditate şi isterie din anterioarele producţii ale directorului de scenă - printr-o coerenţă, subtilitate şi măsură cu totul neaşteptate, cu toate că interpreţii principali (Ema Veţean în rolul prinţesei, Florin Coşuleţ, în cel al prinţului) au tendinţa de a-şi ţipa replicile dincolo de limita inteligibilului, iar numărul scenelor redundante - rod, poate, al improvizaţiilor de care artiştii se ataşează - e destul de mare. Dar să nu fim cârcotaşi. „Turandot” - povestea (orientală) a unei prinţese care nu vrea să se mărite, deci îşi supune pretendenții unei probe-limită, răspunsul la trei întrebări încuietoare (proba Sfinxului, nu-i aşa?), pe care cei mai mulţi nu-I pot da, pierzându-şi astfel, la propriu, capul, până când un candidat neaşteptat rezolvă dilema şi-i cucereşte doamnei mâna şi inima - e foarte inteligent plasată de Zholdak în lumea naţional-socialismului german, obsedată de respectarea tradiţiilor patriarhale. 0 ipocrizie, la urma urmei, căci ura lui Turandot faţă de bărbaţi are o raţiune, sugerată, extrem de precisă şi traumatizantă: a fost şi este abuzată sexual de propriul tată (iar Constantin Chiriac, în rolul acestuia, e cât se poate de convingător în sobrietatea lui marţială, rizibilă în contextul dat). Împăratul îşi iubeşte fiica în toate sensurile cuvântului, are porniri bărbăteşti, sexuale, dar şi paterne, tandre, iar între el şi Turandot se dezvoltă o tensiune constructivă. Detaliile narative stau cam în două ace, fapt care nu dăunează, însă, categoric spectacolului, a cărui dramaturgie mizează in extenso pe ceea ce s-ar numi lucrul cu obiecte imaginare. Şi pe o reţea de semne şi simboluri - cum ar fi metamorfoza prinţesei într-o insectă uriaşă, o călugăriţă dintre cele care-şi devorează partenerul, sau întregul ritual al "prinderii în laţ" al candidatei la căsătorie, asociate unui peisaj-decor sonor unde sunetele, la rândul lor asociate gestului sau mișcării, substituie gestul sau mişcarea însăşi. (Scenele excesive, pornite din exerciţii de improvizaţie, de care vorbeam la început, printre care o bătaie de karatiști, dau impresia de a fi fost inspirate de faimosul film „Tigru şi dragon", dacă tot e vorba, în originala „Prinţ̧esă Turandot", de Împărăţia Chinei. lar dacă e de făcut o hartă a referinţelor comune, şi Radu Afrim foloseşte, din când în când, aceeaşi tehnică a efectului - sonor şi de mişcare - ce înlocuieşte cauza.) De departe cea mai interesantă dimensiune a spectacolului o reprezintă scenografia lui Dragoş Buhagiar. E vorba despre un decor cu tavan - întoarcere la o practică abandonată în ultimele decenii, mai ales în teatrul românesc -, al cărui perete de fundal e un imens basorelief cu trupuri antice contorsionate (un reflex uşor wagnerian, trimiţând şi la obsesia nazismului pentru lumea clasicismului grecesc) şi care, la prima vedere, e un spaţiu închis, fără nici o ieșire aparentă. Nici o ieşire, alta decât prin cel de-al patrulea perete, reinvestit nu doar cu drept de existenţ̧ă, ci şi cu aferenta cortină. Care întoarce teatrul la epoca în care spectacolul era „o felie de viaţă", un fragment, oferit privirii, dintr-un continuum al vieţii. Finalul spectacolului compensează multe lipsuri precedente: în timp ce împăratul ţese un minuscul goblen, pe scenă, acul, mânuit de filiformul povestitor mut din debut, apare supradimensionat, ţ̧esând aceeaşi poveste şi reducând figurile umane, prin comparaţie, la dimensiunea unor păpuşi, cu tot cu mișcarea lor sacadată şi stângace.

E o imagine senzațională, creată cu inteligență, care anulează greutatea atmosferei iniţiale, aducând-o înapoi, la Carlo Gozzi şi lumea lui de basme serioase, în care povestea nu e decât un produs al fanteziei câte unui păpuşar pe jumătate nebun. lar cortina imaginară e trasă la loc.

\section{The return to the story - „Turandot Princess”, National Theatre Sibiu}

Theatre critic lulia Popovici talks about the show that represents a special event in the frame of the Romanian National Theatre Festival 2009: "Turandot Princess" after Carlo Gozzi, directed by the controversial Andryi Zholdak. "The staging contradicts our expectations of violence, physical and psychic aggressiveness, nudity and hysteria we could find in the past productions of this director. This time we are offered coherence, subtlety and a totally unexpected balance" says Popovici. The last scene in this production is a sensational image that makes you think Gozzi's story was told by a half-crazy old man. And than the curtain falls. 


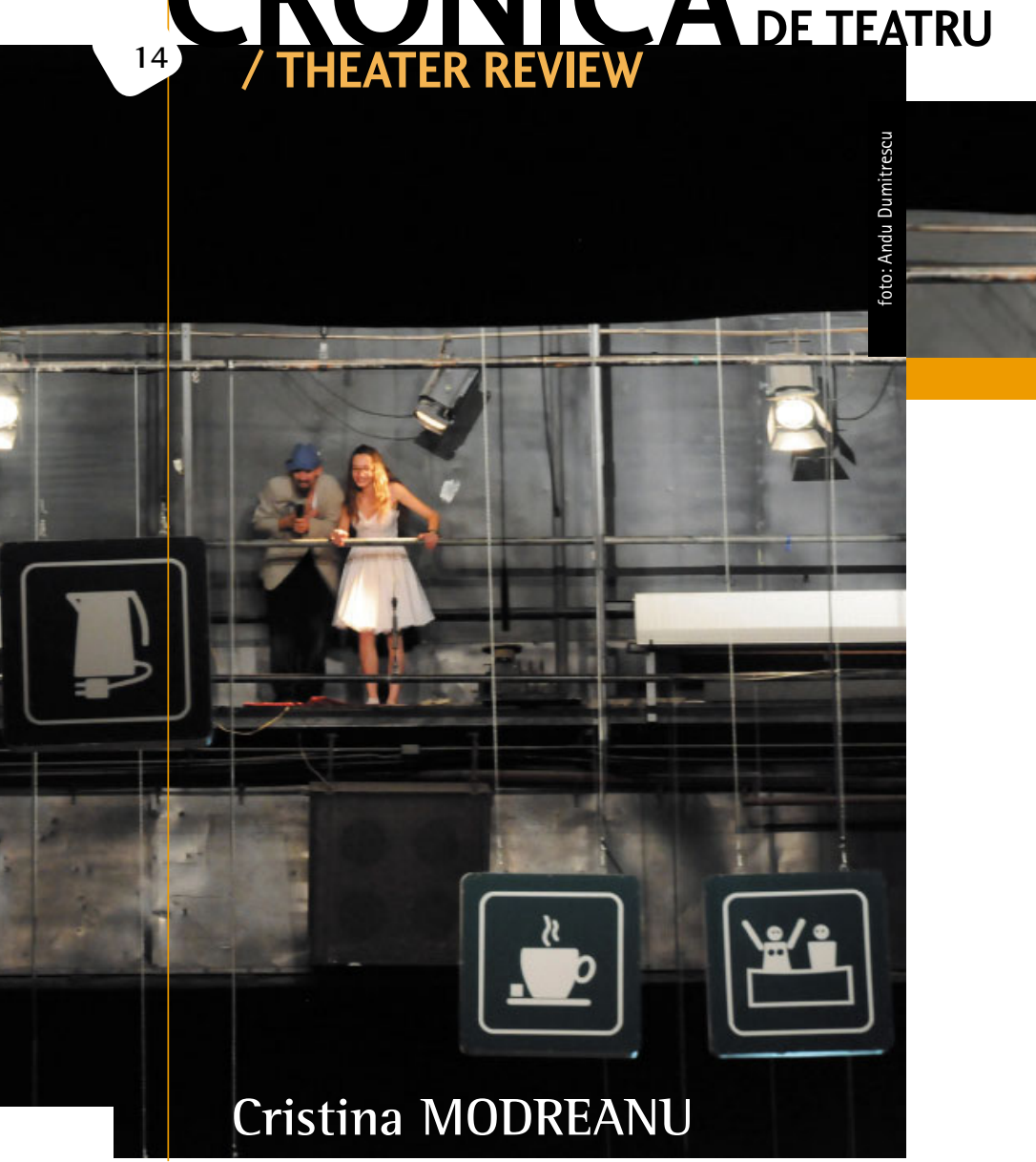

\section{Cristina MODREANU}

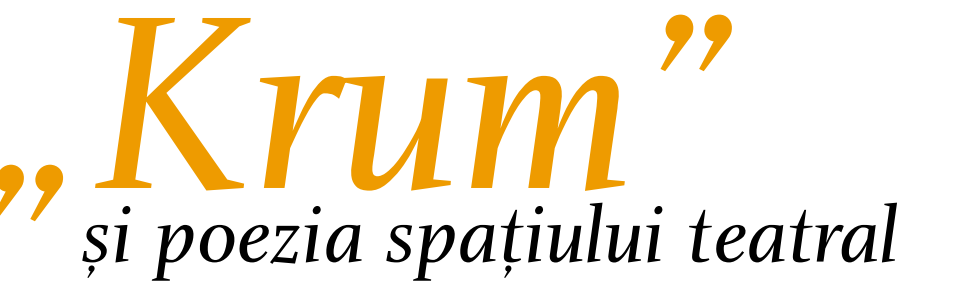

Ştiţi clişeul acela vechi şi obosit „o viaţă în teatru?” Ei bine, clişeul trebuie să mai aibă ceva viaţă în el, de vreme ce există un spectacol care poate fi sintetizat chiar aşa, fiind în acelaşi timp cât se poate de contemporan şi de tulburător.

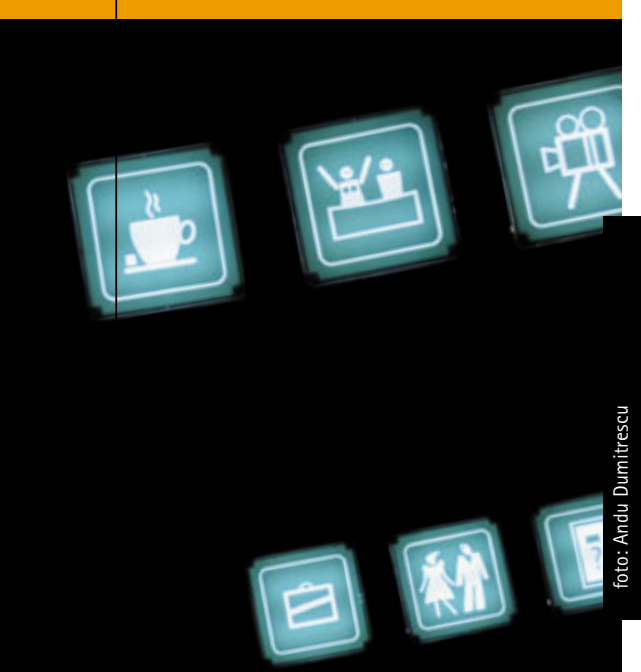

E vorba despre „Krum", în regia lui Theodor Cristian Popescu şi scenografia lui Andu Dumitrescu, producţie a Naţionalului din $\mathrm{Tg}$. Mureş, trupa românească - un teatru căzut în uitare vreme de ani buni, dar care promite să renască dacă i se va da o şansă (şansă însemnând un buget decent şi numirea unui director care să-I scoată din starea în care se află).

„Krum" (excelent tradus de Cristina Toma) e un prim pas în această direcţie. Un pas făcut cu economie de buget, după cum am aflat imediat după ce I-am văzut. Când n-a mai contat însă, fiindcă ideea atât de
Krum and the poetry of the performing space - National Theater from Tg. Mures

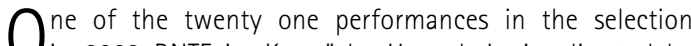
in 2009 RNTF is "Krum" by Hanoch Levin, directed by Theodor-Cristian Popescu, a production of the National Theatre from Targu-Mures. Cristina Modreanu succeeds in giving the highlights of the show: „Besides the simple and genial idea of Andu Dumitrescu who plays with the perspective and the innovative "derailments" of the director Cristian Theodor Popescu, the young actors from Targu - Mures prove to be a treasure hidden in a closet for years: Mihai Craciun, Csaba Ciugulitu, Elena Purea, Roxana Marian, Ionela Nedelea and especially Vero-Nica as Dupa (an explosion of spread energy, trying to hide its hesitations with large gestures, a leaped walk and a fast-forward kind of speach, as if she wants to produce the confusion of the opponent) - are a discovery that truly deserves to be made."

simplă şi de fascinantă a scenografiei lui Andu Dumitrescu, atât de bine exploatată regizoral de Theodor-Cristian Popescu mă cucerise deja şi nu mai conta de ce anume cei doi apelaseră la ea. Această idee mizează deplin pe poezia spaţiului tetaral, care este redescoperit sistematic, ungher cu ungher. Ceea ce ți se deschide în faţa ochilor este nu o scenă, ci întreg teatrul, inteligentul joc cu perspectiva practicat de cei doi fiind de natură să te seducă instantaneu. Scenele binecunoscutei piese a lui Hanoch Levin (montată la noi de puțină vreme şi de Radu Afrim la Naţionalul din Timişoara) se joacă pe mai multe planuri, una în balconul de vis-a-vis de scenă, alta într-un balcon lateral, câteva pe culoarul de siguranță din fundalul scenei, printre reflectoare, una absolut memorabilă în prim-planul scenei, sau alta cu actorii „atârnând" pe marginea scenei, devenită marginea gropii. Pe aceste planuri se joacă toate momentele vieţii: discuţia cu mama din care fiul înţelege că orice comunicare e suspendată între ei doi, scenele de dragoste între Krum şi Truda, iubita lăsată acasă, scena în care Krum îşi duce prietenul, pe Tugati, pe plajă pentru ultima dată sau scena în care întreg grupul merge să vadă un film la cinematograf.

Dar cele mai speciale sunt de fapt "deraierile" de la banalitatea indusă a vieţii trăite de toate personajele piesei, strânse într-un mic orăşel de provincie şi încorsetate în „ideea de plictiseală provincială". Fiindcă deraierile înseamnă dansul nebun al lui Krum ce are loc în timp ce toţi ceilalţi zac în bezna sălii de cinema sau căutarea disperată a unui nasture al femeii care a spart liniştea plictiselii lui Krum făcându-i sângele să fiarbă, sau scena de sex "acrobatic" prin care Dupa, soţia lui Tugati, încearcă să uite apropierea morţii care e pe cale să-i ia soţul şi să se simtă încă vie.

Deasupra tuturor acestor scene se aprind, după caz, semnele inventate de scenograful Andu Dumitrescu, la prima vedere semănând cu acelea prezente în orice aeroport. Numai că aici există multe variațiuni: pe lângă semnul „legați centurile" găsim un semn pentru cuplu, altul pentru o după-amiază liniş̧ită la cafea, un altul pentru discuţia cu mama, pentru înmormântare sau chiar pentru cele câteva ore pe plajă. Stilizate, elementele principale ale fiecărei scene se strâng toate în acest "spaţiu de trecere" care este scena şi se aprind de îndată ce se desfăşoară scenele ale căror simboluri sunt. Dincolo de ideea simplă şi genială a lui Andu Dumitrescu şi de ineditele "deraieri" regizorale ale lui Theodor Cristian Popescu, de remarcat sunt tinerii actori ai trupei târg-mureșene, o comoară ascunsă în dulap de ani de zile: Mihai Crăciun, Csaba Ciugulitu, Elena Purea, Roxana Marian, Ionela Nedelea şi mai ales Vero-Nica în rolul Dupa (o explozie de energie împrăştiată, încercând să-şi ascundă fâstâceala cu gesturi mari, un mers săltat, şi o vorbire alertă, ca pentru derutarea adversarului - coregrafia Eduard Gabia) - sunt o descoperire ce merită cu adevărat făcută. 


\section{TEATRUL NATIONAL TÂRGU-MURES}

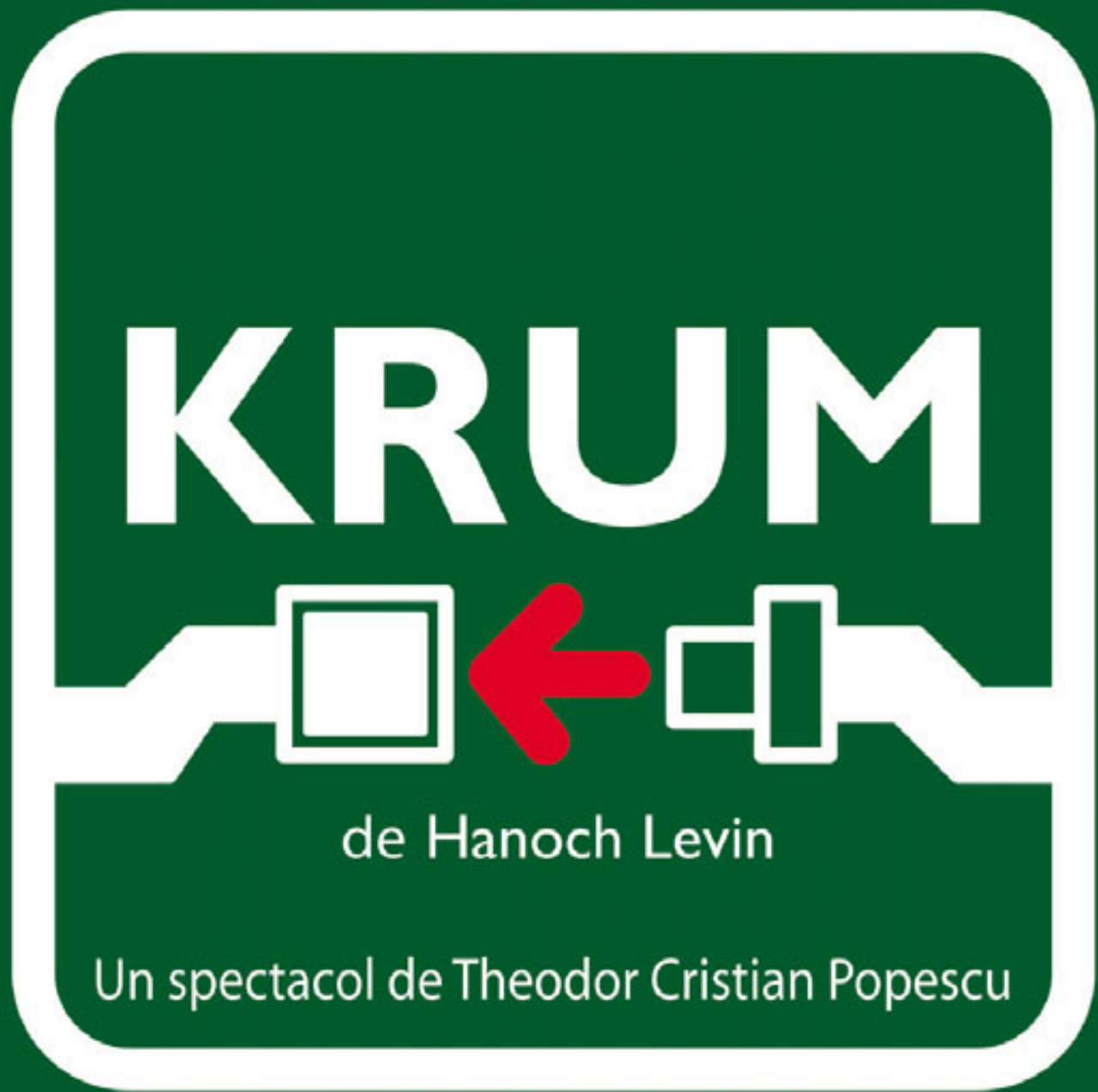

Selectionat la Festivalul Național de Teatru 2009!

MIHAI CRĀCIUN / CSABA CIUGULITU / ION VÃNTU / RAREŞ BUDILEANU / ANCA LOGHIN COSTIN GAVAZÄ / ROXANA MARIAN / VERO NICA / IONELA NEDELEA / LUCHIAN PANTEA / MIHAELA MIHAI regia: THEODOR CRISTIAN POPESCU / scenografia: ANDU DUMITRESCU light design: ANDU DUMITRESCU / THEODOR CRISTIAN POPESCU muzica originală şi sound design: VLAICU GOLCEA / coregrafia și mişcarea scenică: EDUARD GABIA traducerea: CRISTINA TOMA

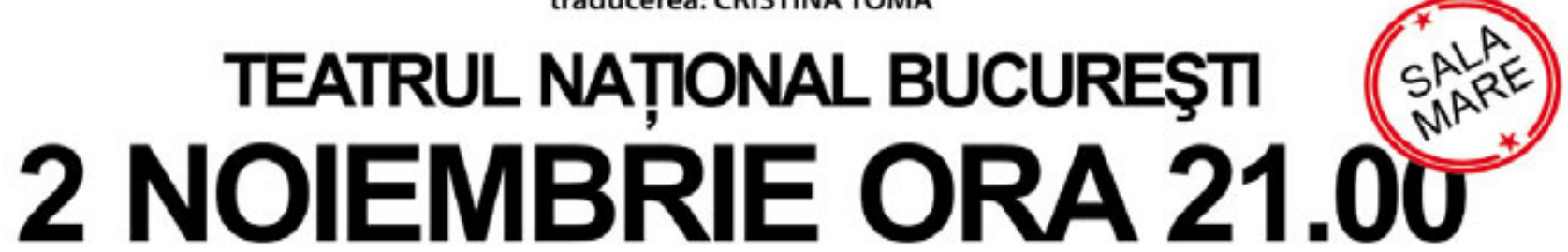

Cu sprijinul Primăriei Municipiului Târgu Mureş 


\section{PROMO}

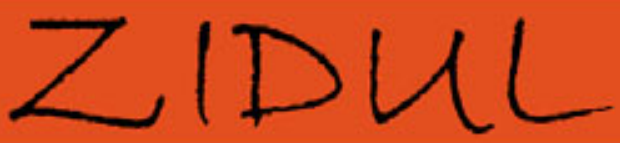

de Theo Herghelegiu

Regia artistică: Theo Herghelegiu

Scenografia: Dan Titza

Coregrafia: Andreea Duță

Conducerea Muzicală: Iustin Gâlea

Soundtrack: Eduard Jighirgiu
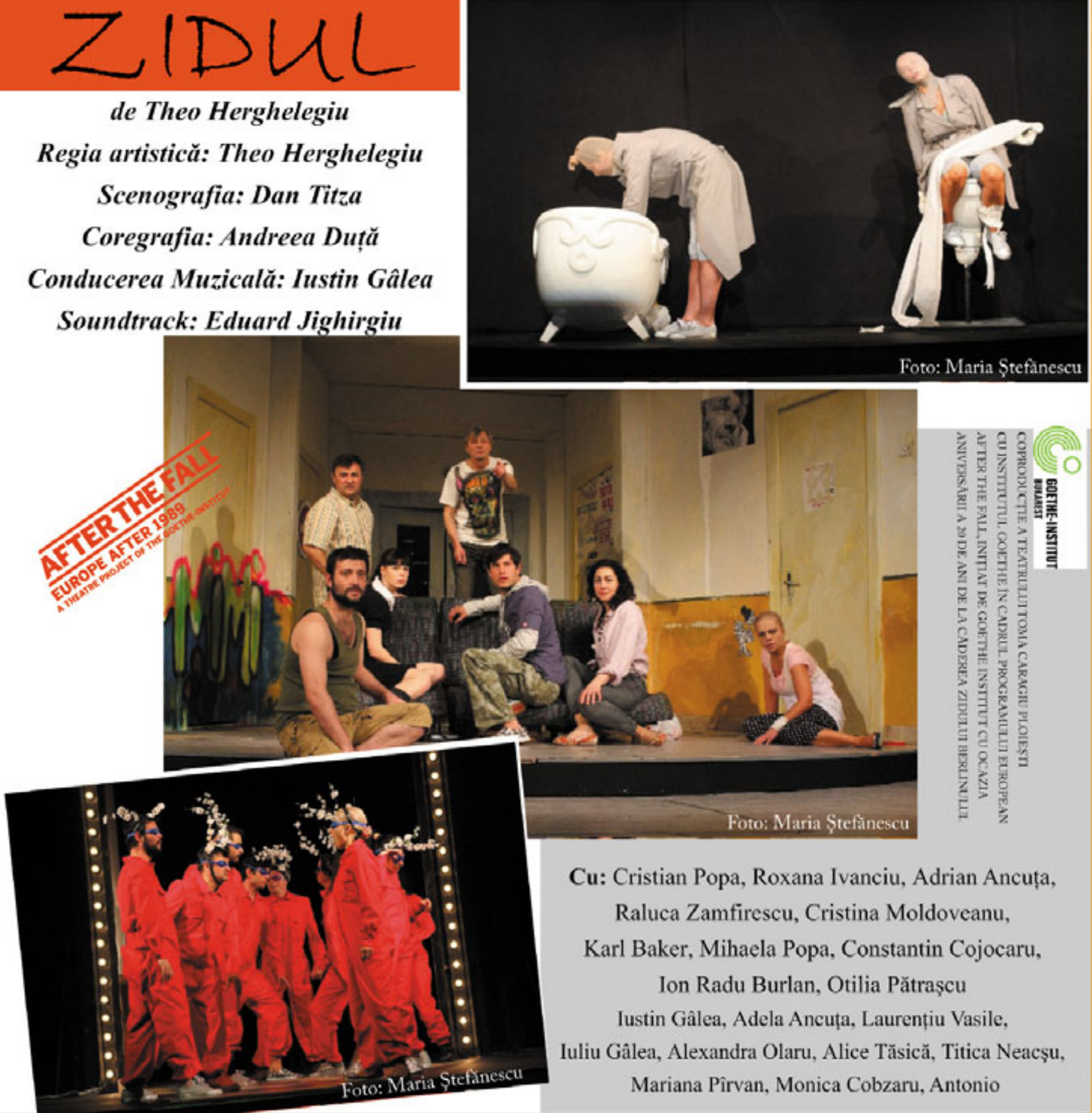

Din când în când îmi sunā-n creieri cuvintele Sybillei Berg (o fabuloasā dramaturgă din fosta RDG): "Oricum mori într-o zi; și dacã trāiești cu frică şi dacă trăieşti în afara fricii. Așa că de ce sa nu încerci să scapi de ea!? S-ar putea ca viața ta să arate altfel. Mult mai bine". Asta încerc să fac să-mi ucid fricile. Nu e uşor, nu e un proces rapid. Dar mă străduiesc. Cred că avem nevoie de acte de curaj. În lume, în viață, în artă. În teatru. Cred că românii ar trebui să facă mai des exerciții de onestitate și să-și antreneze curajul de a spune NU adevăratei violențe, adevăratei vulgarităti, adevăratei manipulari. Cred că este momentul să începem a discerne falsul de autentic. Cred cã este nevoie de curătenie generală.

Theo Herghelegiu 
Beautiful, an exercise of style

The Theatre critic Doina Papp finds the stage design conceived by Andu Dumitrescu in the performance "Beautiful" by Jon Fosse, directed by Vlad Massaci, a production of "Toma Caragiu" Theatre from Ploiesti truly memorable. The stage design consists in fact of a platform on which is written FRUMOS and "a forest of microphones" so that the audience can catch all the whispers and sometimes the sighs of the characters. Doina Papp also observes that Scandinavian new drama became very popular in Romania with the sustained efforts of Bucharest based Carmen Vioreanu (translator and also a director herself) and Sanda Tomescu (translator from Cluj) and with the help of important Romanian directors.

\section{CRONICA T THEATER REVIEW}

\section{1}

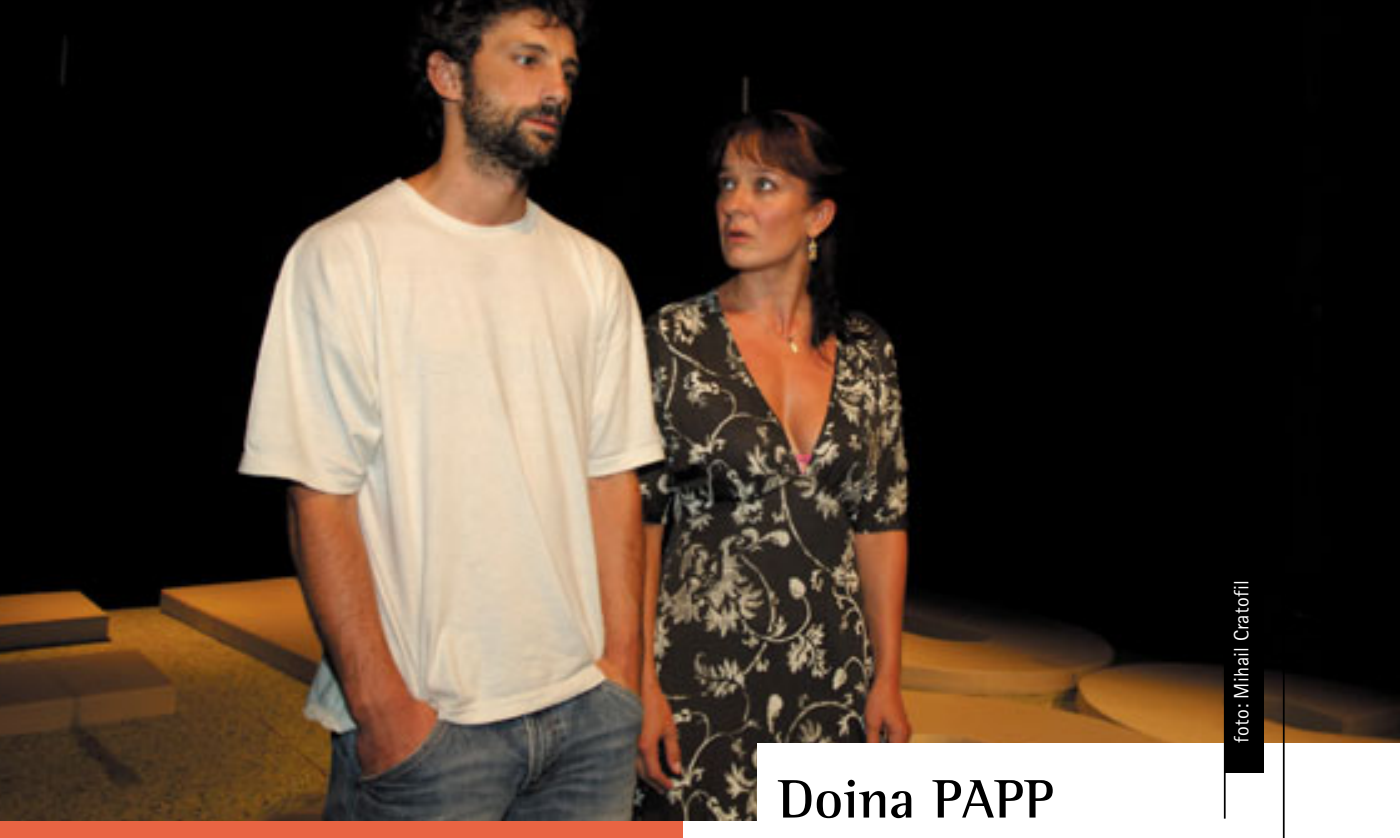

mai bine decât ceilalţi. Nu trebuie să râzi de ceilalţi. Nu trebuie să crezi că celorlalţi le pasă de tine. Nu trebuie să crezi că îi poţi învăţa pe ceilalţi ceva." Aşa ar putea suna un decalog al unui om la locul lui după model norvegian, dar şi al defetistului care se poate traduce printr-o justă măsură a lucrurilor, dar şi printr-o linearitate a existenţei, periculoasă pentru progres, am zice. Ca să nu se ajungă aici, autorul propune în final o deschidere sugestivă. Tinerii aleg să rămână cu bunica, cel mai normal personaj din piesă, şi cu chiseaua ei cu bomboane, în timp ce cuplul în criză se va întoarce în braţele oraşului care i-a pervertit. Triada natură-cultură-civilizaţie e luată şi ea în vizor fără ca autorul să tranşeze în favoarea vreunui termen al acesteia, de vreme ce ratatul piesei, Leif, contină să îşi plimbe însingurarea în cel mai pur peisaj norvegian. Şi fiindcă tot vorbeam de echilibru, să considerăm piesa lui Jon Fosse o binevenită temperare a exceselor sudice care ne caracterizează în viaţă ca şi în artă. 0 altă concepţie despre FRUMOS.

frumoasă, fiecare rătăcind prin impasuri existenţiale nedefinite. De aceea, ei calcă în picioare, la propriu, cuvântul gravat pe podeaua scenei, care nu e altul decât cel care dă şi titlu piesei, explorând echilibrul fragil al reîntâlnirii şi încercând regăsirea de sine pe cont propriu. Prin prietenie, prin întoarcere în timp, prin experienţe erotice. Felul în care se tatonează încercând noi drumuri unul spre celălalt poartă semnele talentului lui Jon Fosse, poet al tăcerilor şi al banalului, a cărui discreție se cere simţita şi respectată fără violentări de ritm sau tonalitate. Ceea ce se şi întâmplă în spectacolul lui Vlad Massaci, chiar dacă efectul e pe alocuri soporific, şi anume atunci când actorilor le lipseşte combustia interioară sau capacitatea de a da relief în formă artistică unor frustrări redeschidem discuţia despre banalul din viaţa şi banalul de pe scenă puternică imagine a spectacolului. Şi o pădure de microfoane care atârnă de la pod pentru a le capta şoapta şi eventual oftatul. Relaţiile sunt formal-geometrice. Distributia în plan are rigoarea unei mişcări pe tabla de şah. Totul pentru a ne sugera existenţele paralele cu intersectări întâmplătoare şi un echilibru precar, amăgitor, al personajelor.

Sub numele „Legile lui Jante", poetul norvegian Aksei Sandemose, citat în caietul program al spectacolului, desemnează ca trăsătură a culturii norvegiene modestia. „Nu trebuie să crezi că eşti special. Nu trebuie să te consideri mai înţelept decât ceilalţi. Nu trebuie să crezi că eşti mai inteligent decât ceilalţi. Nu trebuie să te comporţi ca şi cum ai fi mai bun decât ceilalţi. Nu trebuie să crezi că ştii mai mult decât ceilalţi. Nu trebuie să crezi că te poţi descurca 


\section{PROMO}

Deutsches Staatstheater Temeswar
Teatrul German de Stat Timişoara

Spielzeit - Stagiunea 2009 / 2010

im Rahmen des Nationalen Theaterfestivals în cadrul Festivalului Naţional de Teatru

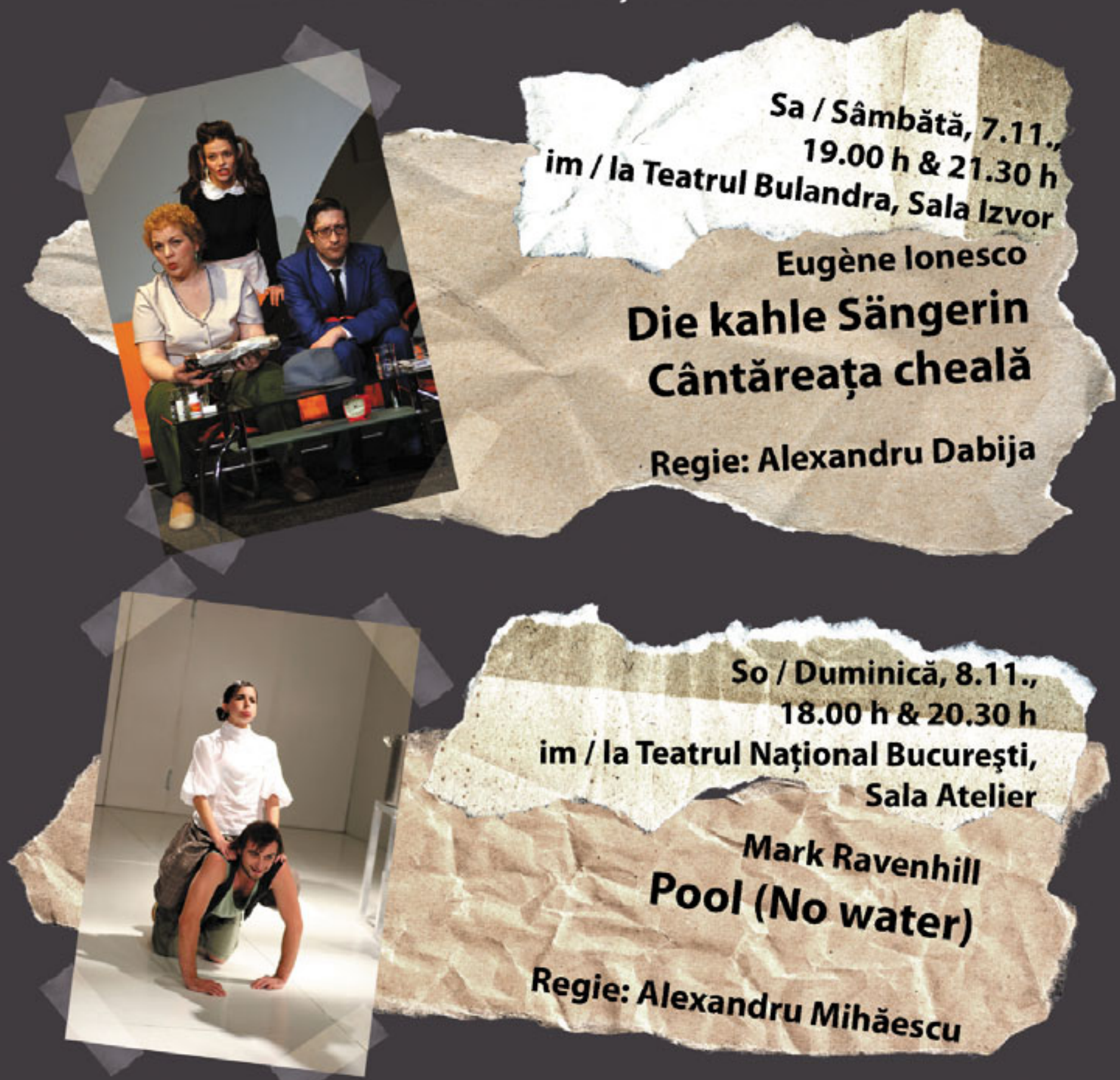


Descompunerea cuplului, a ideii de familie în general este extrem de actuală la început de secol XXI, când se discută deja despre o tendinţă de revalorizare a acestui concept de către generaţiile care vin, de aceea textul lui lonesco capătă acum o nouă rezonanţă. Postmodernitatea a "ronţăit" de-a dreptul conceptul de familie, trimiţându-I într-o zonă de absurd, de aceea textul lui lonesco capătă rezonanţă şi prin această prismă. 0 serie de ticuri amuzante ale soţilor Smith - el se piaptănă prea des, admirându-se în oglindă, ea se aruncă să facă gimnastică, atunci când te aştepţi mai puţin, iar sexul conjugal arată şi el ca o repriză de gimnastică acrobatică - constituie reţeaua de gesturi absurde ce impregnează spectacolul dincolo de text. Sunt gesturi automate, dincolo de care se citeşte chiar ura unuia faţă de celălalt, atent mascată însă prin comportamentul de suprafaţă. Distanţa dintre cuvânt/limbaj şi limbajul corpului a depăşit stadiul de fisură şi s-a transformat în prăpastie vizibilă. Şi de câte ori nu vedem situaţii similare în realitate, uneori chiar în cupluri ce rezistă eroic de o viaţă întreagă, mimând tandreţea în faţa celorlalţi? Reuşita montării lui Alexandru Dabija, citită în această cheie, este în primul rând aceea că textul ne sună extrem de proaspăt, iar umorul lui e redescoperit în acest studiu asupra cuplului - cu exemple din două vârste diferite. Climaxul acestei stări este redat perfect de „amnezia conjugală" de care sunt loviţi soţii din cuplul Martin, 0 întreagă scenă fiind dedicată reamintirii - se recunosc fiindcă stau la aceeaşi adresă şi au un copil în comun. Un fel de moarte interioară pare să-i fi lovit pe protagonişti, transformându-i în personaje de carton, ghidate de autor ca nişte marionete. Însăşi alegerea instalării într-un timp anume - decorul şi atmosfera de comedie poliţ̧istă trimit la anii 60-70, iar muzica e desprinsă din aceeaşi epocă - poate fi interpretată ca o identificare a momentului în care degradarea conceptului de familie a început. La un alt nivel, această alegere devine 0 altă sursă de umor - intrările în scenă au mister şi suspans, iar spectacolul începe cu un dans dezlănţuit al servitoarei casei. De altfel, servitoarea pare singura fiinţă vie, raţională şi imprevizibilă din peisaj (plină de nerv şi strălucire se dovedeşte actriţa Olga Török). Servitoarea face raţionamente de tip detectivistic, merge la film cu băieţii, îl cunoaşte şi pe "stingătorul de incendii" (asocierea ei cu Sherlock Holmes spune, de fapt, că este interesantă, captivantă, amuzantă). Ea singură scapă sindromului contemporan care este plictiseala - toată lumea suferă de el, chiar în timp ce-I generează, prin lipsă de spirit şi curiozitate şi tot ea, plictiseala, subminează şi cuplurile, cum subminează viaţa noastră în general. Cât de plictisiţi pot fi nişte oameni care cred că un tip care se leagă la şireturi şi unul care citeşte ziarul în metrou sunt "fascinanţi"? Absurdul face parte adânc din realitate, nu mai e o categorie separată, generată de limbajul sau de unghiul de privire atât de personal găsit de lonesco, ni se reaminteşte. Atenţia sesizează disfuncţiile, iar lonesco a fost de bună seamă extrem de atent, atent până la a „vedea enorm şi a simţi monstruos", cum spunea Caragiale.

Toate clişeele schimbate de obicei între bărbaţi şi femei (bărbaţi care ţin să aibă mereu dreptate, femei care se apără automat una pe alta), se regăsesc aici intenționat şi produc o senzaţie de mortificare generală (excelenţi se dovedesc tinerii actori ai trupei germane din Timişoara - Ioana lacob, Radu Miodrag Vulpe, Rareş Hontzu, Isolde Cobeţ). Ironia autorului e şi mai limpede când trimite un pompier în scenă (aici Boris Gaza): acesta apare de niciunde şi caută un „incendiu", tocmai pentru a deveni şi mai evident că aici nu este nici un foc de stins.

Până şi discursul pompierului mi s-a părut a căpăta noi semnificaţii în acest spectacol: povestea aberantă, imposibil de urmărit în încrengăturile ei, pe care o spune acesta, devine un comentariu asupra spulberării poveştii în forma ei clasică, romanul. Romanul ca formă de expresie artistică defineşte secolul al XIX-lea, iar odată cu acesta el a fost supus unei explozii care se definitivează abia după un secol. Cum spunea celebrul regizor polonez Krystian Lupa: „Arta spunerii de poveşti, romanul mai presus de toate, este un

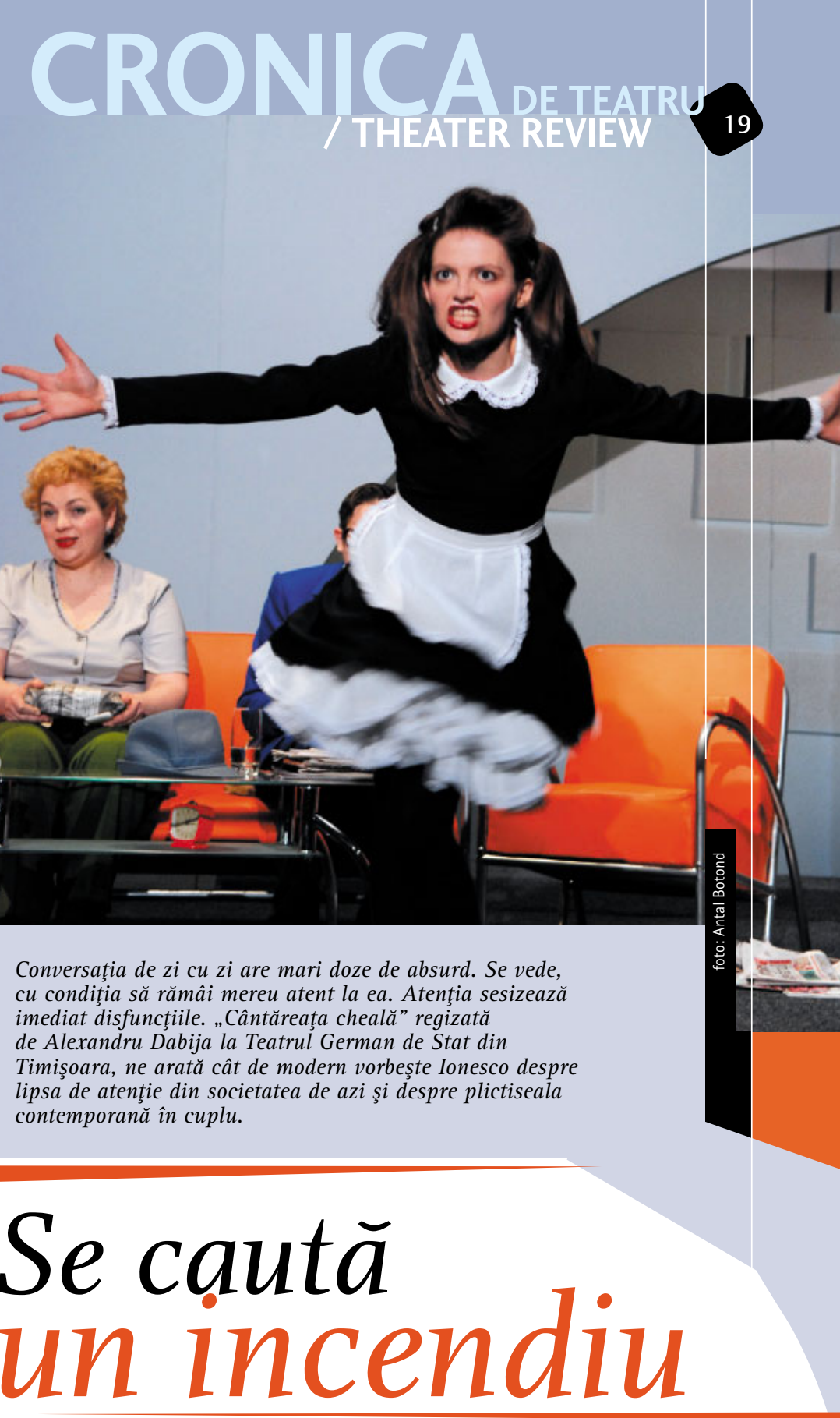

Cristina MODREANU

copil al secolului al XIX-lea. E deja depăşit", intuiţ̧ie pe care lonesco 0 are cu decenii înainte şi la care face trimitere prin inserarea acestui discurs abracadabrant al pompierului. 0 altă sursă de umor şi de fină ironie este exemplara ipocrizie burgheză a celor două cupluri - oameni care se uită în oglindă şi nu se văd pentru că nu sunt cu adevărat vii. Când servitoarea şi pompierul se „înfierbântă" în faţa lor, cei patru îşi feresc privirile de teamă că vor fi nevoiţi să comenteze. Căci poezia gesturilor dezlănţuite are ecou numai în cei care $n$-au murit de tot.

\section{Searching for the fire - Bald Soprano, German State Theatre, Timisoara}

Cristina Modreanu sees in „The Bald CSoprano", production of German Theatre from Timisoara directed by Alexandru Dabija, a refined inside on the contemporary boredom in life of the couple and in the effects of the lack of attention in today's society. In addition, the theatre critic states: "The day to day dialogue has many absurd elements. One can observe that just by being always focused on it. The Attention immediately sees the dysfunctions." 


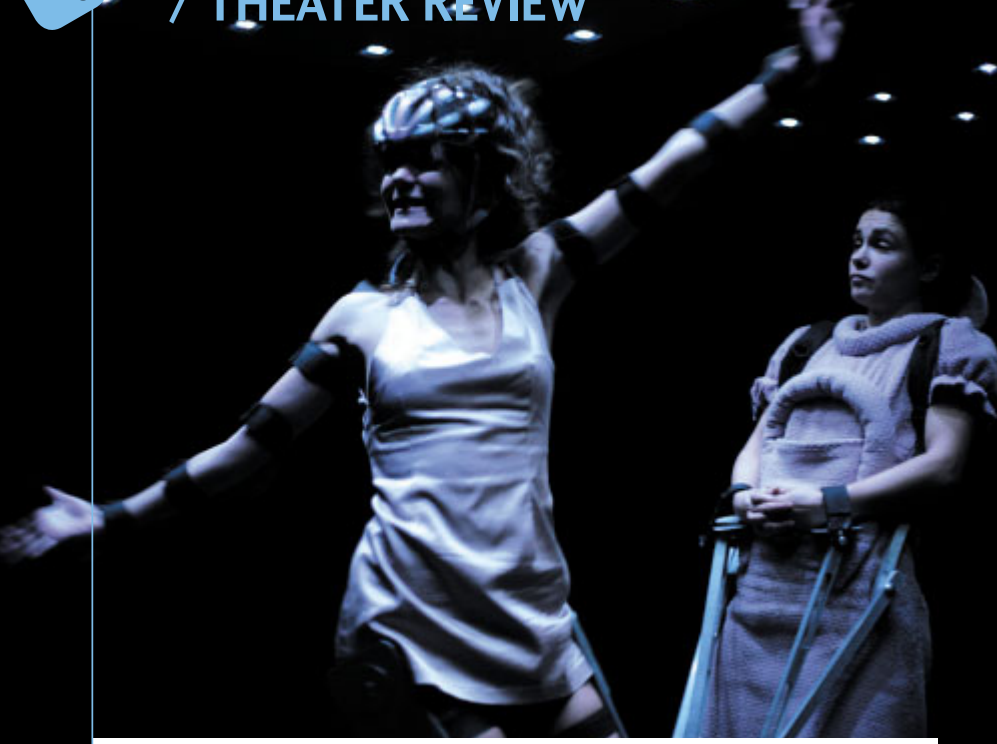

Eugenia Anca ROTESCU

\section{Viitorul}

Dramaturg şi regizor al propriilor texte, Gianina Cărbunariu are de asemenea o relaţie aparte $\mathrm{cu}$ spaţiul de joc, fapt ce impune implicit, de fiecare dată, un mod special de raportare al publicului la reprezentaţie. Constantele acestei relații sunt formulele neconvenţionale şi apropierea spectatorilor de locul acţiunii. Chiar şi atunci când ele nu sunt neapărat inedite - pentru că, nu-i aşa, ne-am obişnuit între timp să urcăm pe scenă, să stăm pe gradene şi să împărţim în teritoriul comun cu actorii - au forţa de a aduce ceva cu adevărat nou, de a se încărca de alte semnificaţii pe care să le resimţi ca spectator și la care să reflectezi. Spectacolul "Poimâine, alatăieri" de la Teatrul Mic nu face excepţie. Regizoarea aşază publicul pe două laturi, iar între acestea lasă o fâşie neagră, destul de îngustă, vag luminată, de-a lungul căreia se dezvoltă montarea sa (scenografia, Andu Dumitrescu şi Andrei Dinu). Modul în care funcţionează lucrurile dau acut senzaţia de masă compactă indistinctă a spectatorilor, iar reducția la unu, la individ, se face aproape de la sine. Şi atunci, prin intruziunea actorilor, fâşia de joc devine nu doar o breşă în corpul social, ci se transformă într-o plagă supurândă muşcând din universul personal. Receptezi astfel cu intensitate sporită imaginea dezumanizată a unui viitor care a început deja, ale cărui semne le recunoşti în tine şi în jurul tău. Un viitor care împinge până la consecința ultimă zelul ecologic, idiosincraziile faţă de fumători, obsesiile biotehnologice, propensiunile spre un vegetarianism autoatesalvator ce câştigă tot mai mult teren în societatea contemporană.

Secvenţe scurte, închise dramaturgic, prezentate prin juxtapunere,

construiesc caleidoscopic un viitor al sfârşitului. Umanitatea dispare din grija pentru sănătate şi mai ales, din raţiuni de productivitate. Ritmul spectacolului respectă nota de eficienţă, şi chiar dacă fiecare scenă are respiraţia sa specifică, inserturile de reclame şi anunţuri, precum şi evidenta absenţă a suportului muzical creează un ansamblu al aparenţelor şi al falsităţii, în care agitaţia ţine loc de energie, grimasele de bunăvoință, bruschețea de întâmpinare politicoasă.

Regizoarea Gianina Cărbunariu creionează personaje care au pierdut legătura cu umanul. Trupuri, mişcări şi expresii (mişcare, Carmen
Coţofană) nu mai au nimic firesc, nimic normal. Au devenit toate constructe ale unei ideologii totalitare, ce acţionează în numele unei vieţi împlinite, lipsită adică de sentimente şi senzaţii, de personalitate individuală şi opţiuni existenţiale. Actorii din distribuție - Mădălina Ghiţescu, Paula Gheorghe, Carmen Florescu, Rolando Matsangos, Virgil Aioanei - acoperind mai multe roluri, răspund de fiecare dată provocării de a da expresivitate personajelor prin mijloace performative, străine de realismul psihologic, dar şi de science fiction. Interpretările lor arată că sunt în continuare oameni, dar fără atributele specifice. Îşi anulează graţia, feminitatea sau masculinitatea, spre a aduce în scenă făpturi asexuate, lipsite de voinţă proprie şi de spirit critic, cu trupuri deformate de intervenţii reparatorii prin protezare înalt tehnologizată sau de poziţii imposibile.

Cu toate acestea, în acceptarea entuziast-iresponsabilă a unei evoluţii a mijloacelor ce duce la involuţia speciei, apar fisuri. Viaţa adevărată se insinuează în comportamente profund umane, în dorinţe şi nostalgii, în amintiri şi visuri. Sunt prezentate fie prin costume simbolizând naiv aspirațiile secrete ale personajelor, fie prin replici scurte care refac imaginea unei normalităţi pierdute, fie prin intervenţiile directe şi proprii ale actorilor din finalul spectacolului. Împreună şi pe rând, ei fac un veritabil necrolog al obiectelor aruncate la groapa de gunoi a istoriei, al lucrurilor devenite inutile, uitate ca scop şi utilitate. Reconstruiesc astfel virtual, din fărâme, un univers material al omului care îl sprijină pe cel spiritual, îl fac să existe, îi dau contur, culoare şi sonoritate.

De altminteri, balansul permanent între un poimâine şi un alaltăieri situat deja în viitor are darul de a anula prezentul prin plasarea lui într-un timp pentru care nu există o referinţă clară, un raport exact. Astfel, Gianina Cărbunariu ridică în scenă un text ce are atât valoare de manifest politic, cât şi de reflecţie filosofică asupra lumii contemporane. 
Fire crackers: „Three Sisters” in National Theatre from Timisoara

For the last three years, National Theatre from F Timisoara became very dynamic, being run by "a young manager and director full of energy and very well connected to contemporary theatre - Ada Lupu." Cristina Modreanu continues: "She transformed an inert institution into a platform of contemporary theatre, a dynamic scene, full of events, developing continuously." Added to this, Ada Lupu seems to give also the right amount of energy and commitment to her performances. Referring to "Three Sisters", Cristina Modreanu states: "The director's intention is to bring in front of the audience some very alive people, passionate by life, even if they don't seem to learn how exactly this must be lived. Spinning continuously, like planets around each other, the three sisters and the men around them compose a little fascinating universe, like a butterfly that appears in a winter's morning.
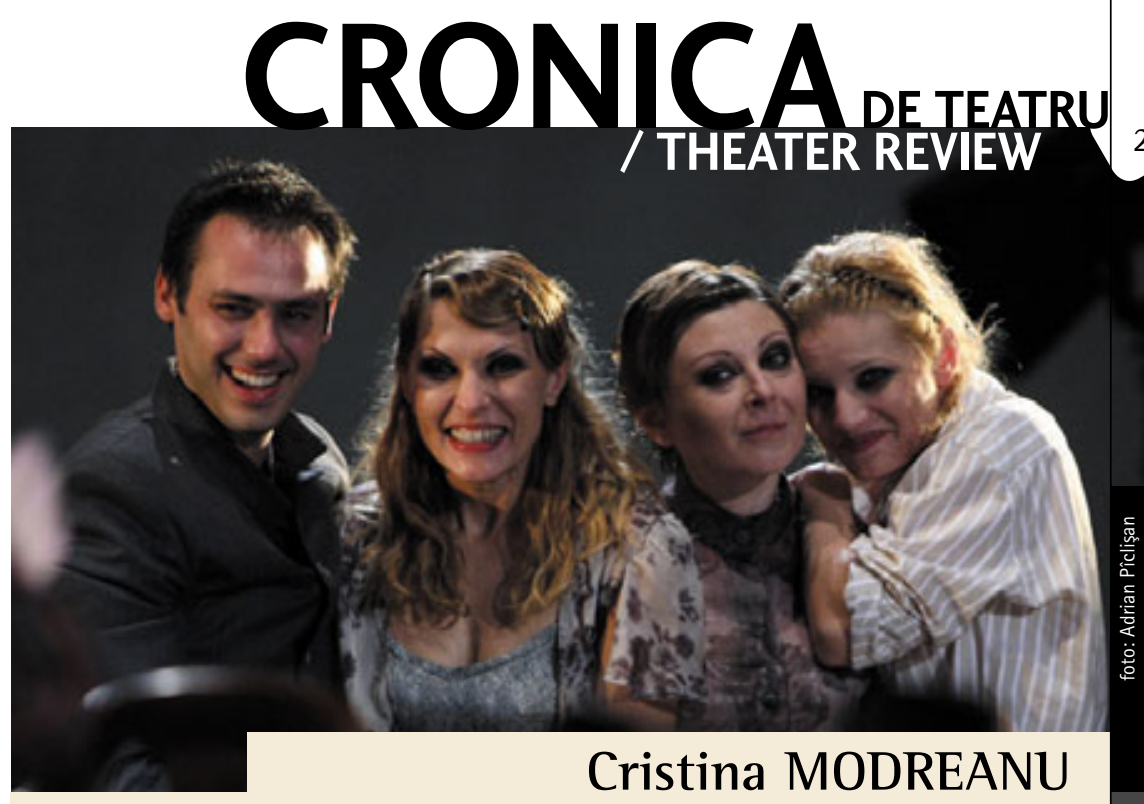

\section{Cristina MODREANU}

Teatrul Naţional din Timişoara este singurul care a făcut o spectaculoasă ascensiune în ultimii trei ani, de când e condus de o tânără regizoare energică şi bine conectată la teatrul contemporan - Ada Lupu. A transformat teatrul dintr-un loc uitat de lumea teatrală într-un avanpost al noii dramaturgii,o scenă dinamică, plină de evenimente, în permanentă dezvoltare. Regizori din toate generatiile au lucrat aici, actorii trupei au fost redescoperiţi de colaborările cu aceştia, Festivalul Dramaturgiei Româneşti pe care $\hat{l} l$ produce a devenit internaţional, instituţia a căpătat două noi săli, a făcut turnee şi a reprezentat teatrul românesc ca invitat al Odéon Théâtre de Paris in această vară. Una dintre puţinele povești de succes din teatrul românesc al ultimilor ani.

Spectacolul cu "Trei surori" de A.P. Cehov este montat la Teatrul Naţional din Timişoara într-un spaţiu complet transformat, construit pe scenă, cu spectatorii aşezați pe toate cele patru laturi. Regizoarea Ada Lupu a imprimat personajelor o stare de exaltare, insistând asupra ei tocmai pentru că este acea trăsătură proprie personajelor lui Cehov care le apropie cel mai mult de contemporaneitate. Toate acele aspiraţii care mor încet în ei îi fac pe aceşti oameni tineri şi frumoşi să exalte, să strălucească, dar nu să ardă cu adevărat, ci să lumineze puţin, asemeni unor focuri de artificii, pentru ca în cele din urmă să se stingă, inevitabil. Ce şi-a propus autoarea spectacolului este să aducă în faţa spectatorilor nişte oameni foarte vii, pasionaţi de viaţă, chiar dacă par să nu reuşească a învăţa cum anume trebuie ea trăită. Învârtindu-se continuu, ca nişte planete unul în jurul altuia, cele trei surori şi bărbaţii din preajma lor alcătuiesc un mic univers fascinant, ca un fluture care apare într-o dimineaţă de iarnă. Cu ajutorul scenografei Velica Panduru spectacolul capătă chiar consistenţa unei aripi de fluture - surorile sunt îmbrăcate în rochii vaporoase, colorate şi numai machiajul lor dramatic te face să te gândeşti la destinul de a rămâne pierdute într-un orăşel de provincie. Covoarele persane aruncate unul peste altul pe jos, lumânările împrăştiate peste tot şi cele câteva piese de mobilier de epocă, dintre care masa mare ce tronează în mijloc devine centrul universului de care vorbeam, completează un spaţiu destinat lâncezirii, un loc plăcut şi propice visării, huzurului, care parcă blocheză orice acţiune, exclude luarea unor decizii şi atenuează dorinţa de reală schimbare.

Dar dincolo de spaţiul de joc transformat, de decor şi de costume, punctul cu adevărat forte al spectacolului sunt actorii şi desenul precis al relaţiilor dintre personaje pe care îl face regizoarea cu ajutorul lor. Alina Reus (Maşa) este aici la cel mai bun rol al său, ataşându-se până la identificare de tânăra femeie măritată prea

Cronică apărută pe www.artactmagazine.ro

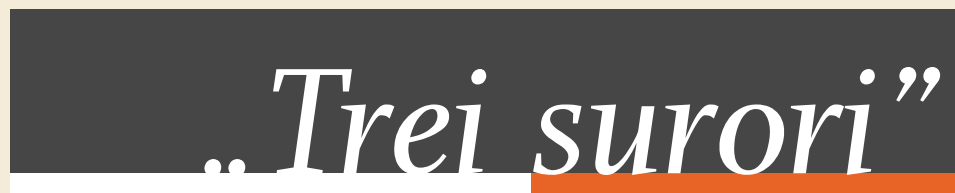

la Naționalul timișorean. Focuri de artificii

devreme şi obişnuită cu tristeţea atât de mult, încât o umbră de bucurie o face să-şi piardă capul. Paula Maria Frunzetti (Olga) este un monument de calmitate şi resemnare, dar lasă să se vadă în privirile ei cum se prăbuşeşte o lume de fiecare dată când cedează în faţa lipsei de bun simţ şi prostului gust al Nataliei (Ana Maria Cojocaru). Claudia leremia (Irina) umple scena cu efuziunile ei, dând tonul exaltării despre care vorbeam mai devreme, un tip de trăire care apropie personajele şi mai mult de publicul lor de azi. Ea aleargă, îşi schimbă mereu locul, ca şi cum i-ar fi teamă să nu prindă rădăcini, ajunge să defileze pe masa cea mare, încercând să-şi schimbe perspectiva, se înflăcărează de dragul unor vise, apoi se stinge, iar stingerea ei - felul în care e silită să intre în viaţă cu acelaşi bagaj de tristeţe, deşi avea tinereţea şi viitorul de partea ei - întristează mai mult decât drama oricăreia dintre surorile mai mari. 0 surpriză este Verşinin (Ion Rizea) construit parcă să contrazică tot ceea ce ştiam despre acest personaj: nu un "Hamlet de provincie", cum i s-a spus, nu un meşter al vorbelor lipsit de curaj, apăsat de povara soţiei şi a fetiţelor, ci un cuceritor de meserie, tipul dur şi dominator, care ştie să ia ce crede că este al lui. Interpretarea controlată a actorului, parcă refuzând implicarea, subliniază mai bine modificările de tipologie gândite de autoarea spectacolului. Carnavalul din partea a doua a spectacolului este suma exaltărilor tuturor personajelor - Kulîghin (Cătălin Ursu) se costumează în negru şi cu mască şi sare ca un liliac, sporind ridicolul de care e înconjurat permanent ca de un nor, în Tuzenbach (Ioan Strugari) se aud ecourile exaltării Irinei, şi până şi lui Solion îi (Damian Oancea) par să-i sclipească ochii de un surplus de trăire, care va determina însă în cele din urmă finalul tragic al logodnicului Irinei şi nu cine ştie ce act curajos. După acest moment al carnavalului, totul începe să se prăbuşească. Faptul că sunt altfel - cum altfel este şi fratele lor, Andrei (Victor Manovici) - nu le face mai speciale pe cele trei surori, ci doar le condamnă în faţa celor ce au talentul de a răzbi, precum Natalia (ale cărei exagerări sunt bine marcate de Ana Maria Cojocaru). Într-un fel, toţi ceilalţi, inclusiv Verşinin, sunt mai aproape de vulgaritatea Nataliei, lăsându-le şi mai singure pe cele trei surori, ce par, printre postamentele înalte în care stau aprinse lumânări, spectrele unei lumi pe cale să moară. Un fel de „Livadă de vişini" umană.

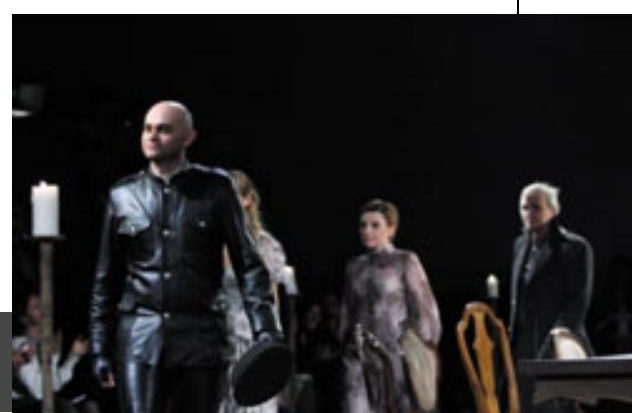





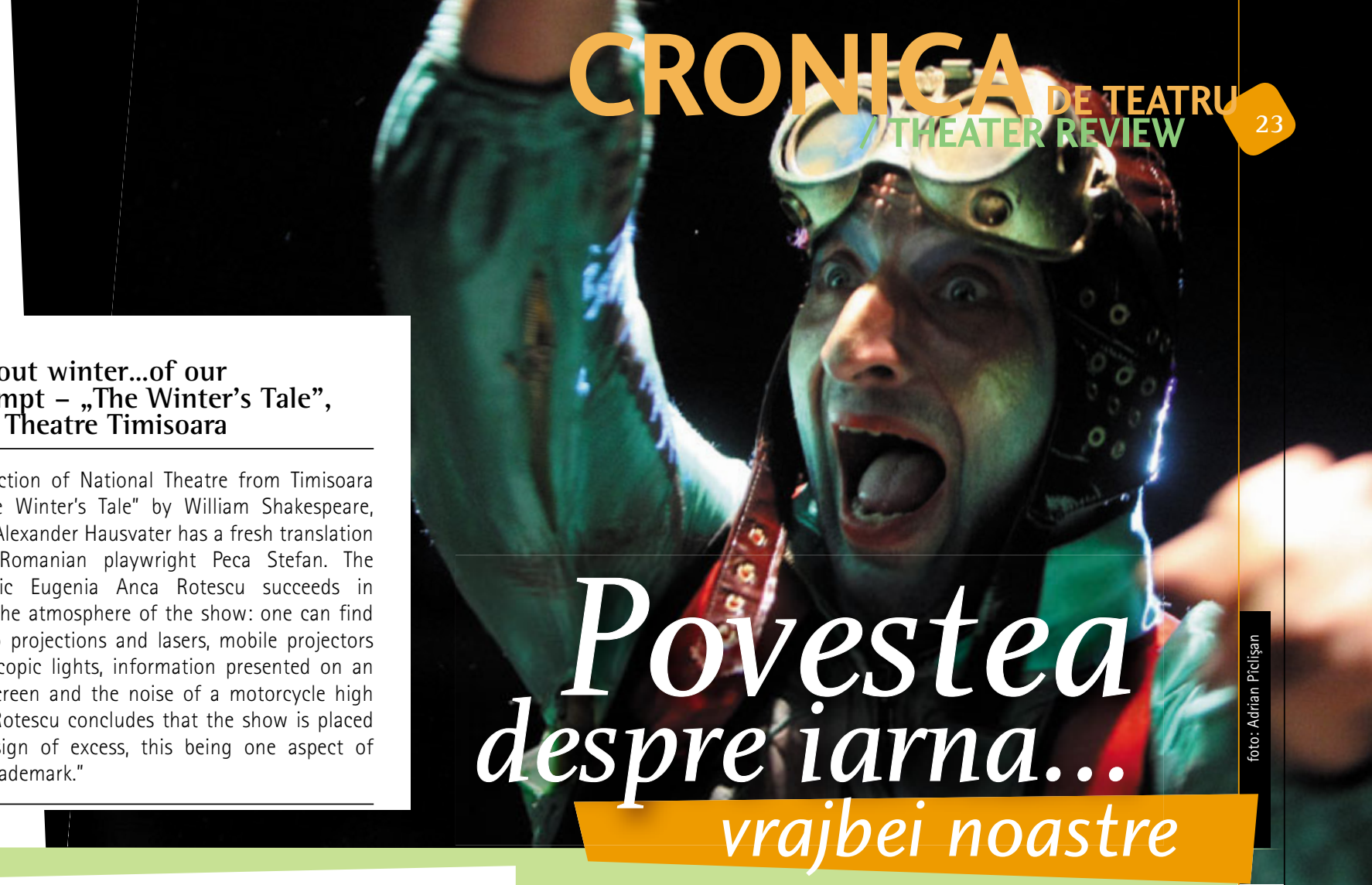

În primul rând, montarea din generoasa Sală 2, unde acțiunea se desfăşoară pe toate cele patru laturi, pare să vorbească despre o globalizare care aneantizează repere de orice fel. Despre evenimente din patru zări care ne privesc direct sau indirect, mai mult sau mai puţin discret, dar care, cu siguranță, ne afectează. Indiferent dacă le acordăm sau nu atenţie, dacă le percepem clar sau voalat, dacă ne aflăm în miezul sau în marginea lor. În orice caz, suntem prinşi la mijloc. Toate acestea le sugerează dispunerea spectatorilor în centrul sălii, cu posibilitatea de a se roti odată cu scaunele ca să urmărească, în condiții de vizibilitate diferite, de la foarte bine la abia zărit, ceea ce se petrece în jurul lor. La dreapta, la stânga, în faţă sau în spate - direcții ce se relativizează și ele, singurul punct de referință fiind doar poziţia iniţială, fără însă a avea certitudinea că acesta este unghiul corect de a vedea lucrurile.

Ceea ce globalizarea aduce cu sine în mod special este violenţa ca parte constitutivă a vieţii cotidiene. Războaiele intra- şi inter-statale sunt la ordinea zilei. Raporturile personale şi/sau familiale sunt mai ales conflictuale. Relaţiile cu mediul social sunt eminamente dificile. De aici rezultă atitudinile ostile ale personajelor, prezenţele ameninţătoare, vorbele răstite şi în consecință, haine militare pe trupuri schilodite, împuşcături fără preaviz, mitraliere în loc de discursuri. Mai mult chiar, individul este în permanenţă supus agresiunii noilor tehnologii ca mijloace de manifestare ale societăţii contemporane. Prin urmare, în montare abundă proiecţii video şi lasere, spoturi de urmărire şi lumini stroboscopice, informaţii derulate pe un panou electronic de afişaj şi stridențele unei motociclete puternic ambalate. Împreună şi deodată, ele nu izbutesc însă să dea substanţă vieţii, rămân forme exterioare, zgomote şi imagini golite de conţinut.

Pentru că ceea ce lipseşte fundamental - şi din realitatea de astăzi şi desigur, şi din spectacol - este comunicarea. Oricât de sofisticate şi de intens folosite vor fi fiind aceste mijloace, ele nu sprijină contactul direct, căldura umană, împărtăşirea. Dimpotrivă, lasă individul singur cu dilemele şi frământările sale. Indiferent de poziția sa pe scara socială. Măsura profundă a acestei însingurări o dau momentele în care regele Leontes rămâne cu sine însuşi, momente cărora atitudinea actorului lon Rizea le conferă dimensiunea tragică a celui pierdut între propriile convingeri şi sentimente, pe de o parte şi de cealaltă parte, jocul şi exerciţiul puterii discreţionare.

Deriva personală în contextul contemporan justifică în spectacolul de la Teatrul Naţional din Timişoara suspiciunile şi complotul împotriva

Primul deceniu al secolului XXI este aproape consumat într-o istorie agitată, din care nu lipsesc conflictele de tot felul şi la toate nivelurile. Ce aspecte ale lumii contemporane ar putea să acopere faptele relatate în urmă cu patru secole de Shakespeare în piesa

"The Winter's Tale”? Acestei întrebări îi răspunde, în maniera sa personală, regizorul Alexander Hausvater, prin spectacolul „Povestea de iarnă” de la Teatrul Naţional din Timişoara.

\section{Eugenia Anca ROTESCU}

prietenului dintotdeauna, regele Polixenus (Ovidiu Crişan) precum şi gelozia şi condamnarea la moarte a soţiei (Claudia leremia). De fapt atitudinea soţului-rege apare pe un fond ce pune acut în evidenţă, prin ştirile de acest tip derulate pe panoul electronic, inegalitatea dintre sexe, discriminarea femeii manifestă atât la nivelul relaţiilor interumane, cât şi ca abordare socio-politică în țările arabe. Modul în care este tratată femeia în familie şi în societatea patriarhală, accesul ei limitat la educaţie sau la participare comunitară constituie premisele care dau bărbatului drept de viaţă şi de moarte asupra soţiei.

Laolaltă, evenimente şi atitudini fac astfel ca lumea contemporană să-şi piardă poezia. Faptul este subliniat încă de la început prin noua traducere a textului shakespearian, semnată de dramaturgul Peca Ştefan. În versiunea sa, arhaisme şi neologisme se intersectează brutal, expresii uzuale se ciocnesc de formulări metaforice, vocabularul colocvial se înfruntă cu barbarisme într-un registru stilistic fragmentar, secvenţial şi contradictoriu, accidentat şi greu de conciliat. De asemenea, moartea poeziei în societatea de azi apare cu pregnanţă în partea a doua a spectacolului, când acţiunea se mută în Sicilia. Aici, tot ceea ce ar trebui să sugereze existenţa fericită şi fermecată din Cealaltă ţară, una a consensului general și a iubirii aproapelui, a păcii şi a convieţuirii paşnice în armonie cu natura, este reprezentat într-o cheie care îi anulează în mod voit credibilitatea. Concepţia regizorală, sprijinită de scenografie - Lucian Lichiardopol, de costume şi măşti - Stela Verebceanu, de muzică - Dan Jinga şi coregrafie - Mălina Andrei, împinge reprezentaţia fie într-o zonă a naivităţii aflate la limita kitsch-ului, fie într-una a elaborării artistice acccentuate, dusă până la limita extremă.

De altminteri, întreg spectacolul stă sub semnul excesului, mai mult sau mai puțin controlat. Dar, cu certitudine, purtând marca Hausvater. 


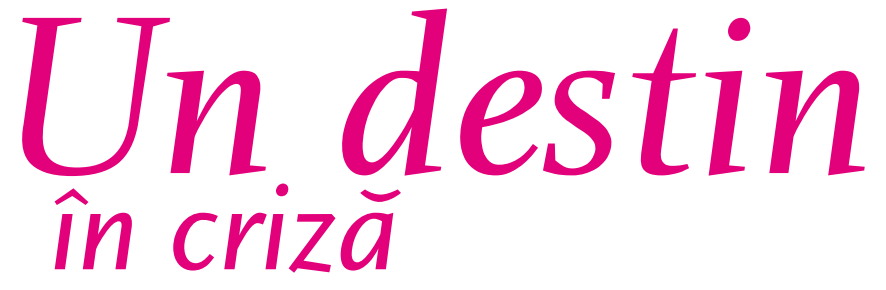

Datorită geniului lui Erdman,

„Sinucigaşul" ni se înfăţişează azi ca o piesă existenţială despre "destinul unui om în criză", cum spune Felix Alexa, regizorul spectacolului de la Teatrul Naţional din Bucureşti. E sigur însă că autorul a vrut, în 1929 când a scris piesa, să acuze mai cu seamă liderii bolşevici pentru care „ "cetăţeanul" devenise o monedă de schimb. Mai mult decât atât, aceștia devin responsabili de pervertirea întregii societăţi reprezentată de Erdman categorial, adică pe clase şi profesii. În prima montare din România din 1991, cu Horaţiu Mălăele în rolul principal, acela care descoperise de altfel piesa şi vroia să o joace încă dinainte de 1989, cel mai aprig suna acuzaţia la adresa intelighenţiei laşe, oportuniste, incapabile să dea o replică regimului inuman instaurat în Rusia. 0 percepţie izvorâtă probabil şi din situaţia internă a României însăşi. Deşi această impresie nu s-a schimbat în opinia publică, spectacolul lui Felix Alexa îi condamnă în mod egal pe toţi, de la afacerişti la clerici, de la artişti la agitatori politici mărunţi. Situaţia lui Poţekalnikov împins la sinucidere de aceștia devine de aceea fără ieşire. Singur în faţa lui însuşi şi a lui Dumnezeu omul oropsit care este capătă accente dostoievskiene ("Umiliţi şi obidiţi”), ducând drama şomerului fără speranţă pe făgaşul unei dezbateri fundamentale. Cine suntem, ce suntem, ce devenim, cât ne aparţine din viaţa noastră şi ce decizii e liber să ia creştinul din noi la ceas de cumpănă (în faţa vieţii de netrăit şi a morţii greu de împlinit, cum frumos spune regizorul). Ne atribuim aceste întrebări şi încă altele ale eroului, pentru că destinul îi transgresează biografia expusă în această poveste banală până la un punct. Despre un om în impas care nu-şi găseşte o slujbă deşi încearcă cele mai fantasmagorice soluţ̧ii (cântatul la tubă), trăind cu umilinţă această condiţie până când îi vine, mai în glumă, mai în serios, ideea de a-şi lua zilele. Aici se produce turnura spre grav a piesei, spre un grotesc gogolian, virajul spre tragicomedie a ceea ce părea până acum doar o farsă. Erdman deschide larg cerul neliniştilor metafizice şi tună cu sarcasm împotriva jocului periculos de-a viaţa şi moartea. Eroul său, copleşit de fariseismul regimului, caută salvarea în sine, de unde-şi adună şi forţa de a se răzvrăti. Dintr-un umil şi supus cetăţean, el devine un contrarevoluţionar (să ne amintim scena beţiei când vorbeşte la telefon cu Stalin ca să-i spună că nu-i place Marx), pe care o manipulare sinistră la care asistăm încearcă să-l elimine. Jocul pervers prin care politica se substituie vieţii pentru a o îngenunchea este 0 altă temă pe care această piesă o conţine, scrisă fiind în anii NEP-ului (începutul şi sfârşitul economiei de piaţă), când puţini ruşi îşi dădeau seama de marea păcăleală servită drept imagine bună a comunismului. Şi pe acest palier, similitudinile cu istoria ţării noastre sunt transparente, nu doar privind la deceniile dezgheţului din anii ' 70 , ci şi la prezentul care suferă de aceeaşi mistificare a adevărului. Mesajul spectacolului este de aceea în acelaşi timp major filosofic şi angajat politic. Planurile sunt echilibrate, deşi în anumite privinţe talerul balanţei înclină spre $0 \mathrm{~m}$ şi spre suflet, iremediabil rănit şi uneori răpus de constrângerile politico-sociale. Aici îi revine un rol esenţial interpretului lui Poţekalnikov, actorul Dan Puric, a cărui aură energetică conţine această trăsătură de umanitate. Amestec de firesc şi forţă interioară, jocul său ni-l apropie pe erou şi frământările sale. În plus, fragilitatea fizică, aspectul imponderabil al prezenţei sale în scenă ne îndeamnă mereu la o privire dincolo de aparenţa materială, concretă a realităţii. Acest efect îl produce şi decorul Ruxandrei Ion, un fundal de uşi pe care circulă ameţitor personajele multiplicate în oglinzi care uneori le deformează figurile. De o parte şi de alta a lor, cei care-l împing pe Poţekalnikov la sinucidere construiesc imaginea unei lumi nesigure şi totuşi opresive. 


\section{CRONICA
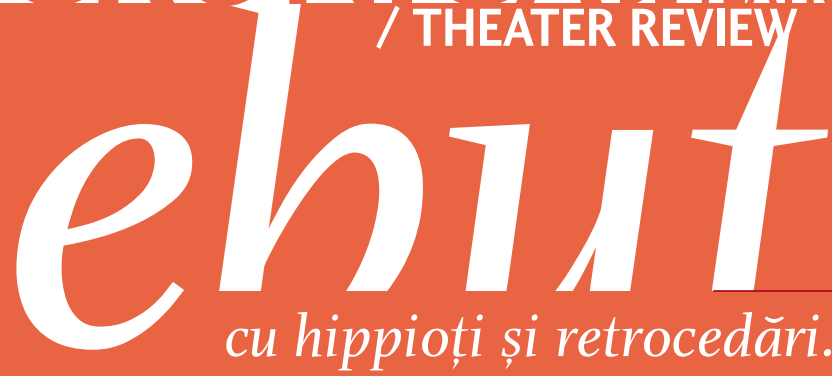

În ciuda calităţilor lor reale, atât regizorii, cât şi tinerii actori pomeniţi mai devreme pot fi văzuţi în locaţiile underground ale Capitalei şi nu pe marile scene care ar avea atâta nevoie de prospeţimea punctului lor de vedere şi de talentul şi entuziasmul care î animă.

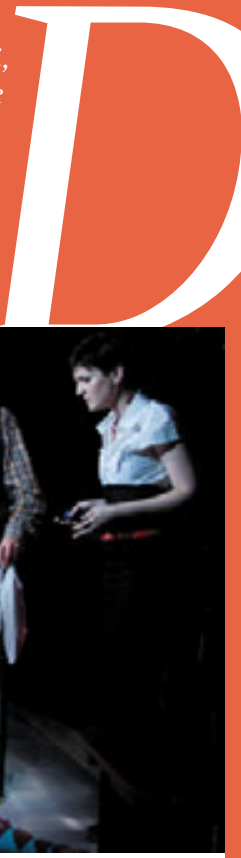

„Faceţi loc!” de Mihaela Michailov, regia David Schwartz; Teatrul LUNI de la Green Hours

0 continuare firescă a preocupărilor regizorului pentru teatrul comunitar, „Faceţi loc!" este expresia revoltei unei generaţii față de aparatul de stat incompetent şi indiferent la problemele oamenilor obişnuiţi. În cazul de faţă, problema gravă a pierderii locuinţelor prin punerea în practică a Legii proprietătii. Având ca axă ordonatoare o serie de interviuri cu actorii din distribuţie, cărora li se pun aceleaşi întrebări menite să-i dezvăluie în faţa publicului aşa cum sunt în viaţa particulară, spectacolul devine un amestec uluitor de realitate şi ficţiune. A avea sau a nu avea - este întrebarea pusă de regizor împreună cu dramaturgul, atât actorilor, cât şi, indirect, publicului, într-un spectacol viu, plin de umor, dar de fapt extrem de serios. Realitate înseamnă interviurile filmate şi proiectate între scenele spectacolului, în care îi descoperim pe actori „în civil", ca şi cum am sta de vorbă cu ei în culise. Şi, cum stăm de vorbă, ei ne povestesc despre casele în care s-au născut şi despre casele pe care le-au schimbat de-a lungul vieţii, despre relaţia lor cu obiectele şi despre proprietate în general. Rodica Mandache povesteşte cu nostalgie despre "casa de la laşi", casa copilăriei, la care se gândeşte şi azi cu drag, Irina Mazanitis răspunde că nu a fost niciodată legată de obiecte şi o repetă până când afirmaţia devine un fel de glumă, dar şi un exemplu de înțelepciune pentru toată lumea, iar Constantin Cojocaru are vie în minte amintirea unei haine de piele de culoare muştar pe care a purtat-o cu mare succes fiindcă atrăgea toate privirile. Elementul uman este excelent surprins şi pus în slujba temei spectacolului, tânărul regizor folosindu-i astfel "la pătrat" pe actori, atât în ipostaza lor profesională, când le dă să joace roluri inspirate din viaţa de zi cu zi, cât şi în ipostaza lor privată, prin confesiunile pe care le provoacă. Spectacolul furnizează astfel "realitate 2 în 1", cum ar spune o reclamă.

Ficțiune egal textele scrise de dramaturgul Mihaela Michailov şi inspirate din poveştile oamenilor din cartierul Rahova, care şi-au pierdut casele prin câştigarea lor în instanţe de foştii proprietari, şi bat de ani de zile zadarnic la uşile autorităţilor, umblă pe la ghişee unde sunt întâmpinaţi de oameni care îi tratează cu dispreţ şi îşi pierd speranța odată cu fiecare zi care trece. Fără să devină patetic nici în aceste părţi ale sale, spectacolul are foarte mult umor şi un aer de autenticitate care te face să uiţi că eşti în Clubul Green Hours, când îl vezi, şi să te simţi tu însuţi în faţa unui ghișeu alături de personaje. Regizorul David Schwartz dovedeşte o neaşteptată maturitate şi o excelentă intuiţie atât în alegerea temei, cât şi în găsirea unei combinaţii de mijloace actuale şi credibile prin care să o redea.

\section{Plus două nume de ținut minte: David Schwartz și Felix Crainicu}

„Hippioţi şi bolşevici”

de Amiel Gladstone, regia Felix Crainicu; Teatrul Arca, Club La Scena

Teatrul Arca din podul clubului La Scena a revenit în peisajul independent toamna trecută, dar cu premiera semnată de Felix Crainicu ca spectacol de absolvire şi-a câştigat din nou locul pierdut pe harta destinaţiilor underground din Capitală. Spectacolul cu piesa „Hipioţi şi bolşevici" scrisă de dramaturgul canadian Amiel Gladstone este pur şi simplu ceea ce se cheamă „un debut strălucit". Într-o lume normală, autorul acestui spectacol ar intra direct „în producție", primind solicitări de la teatre pentru noi spectacole. Pentru că, deşi debutant, tânărul regizor a parcurs cu succes toate etapele "muncii de regizor", adică a ales un text foarte bine scris, cu o temă ce garantează empatia publicului de toate vârstele - 0 poveste de dragoste în timpul mişcării hippie - a alcătuit o distribuţie potrivită, a impregnat spaţiul de joc cu atmosfera epocii respective, $i-a$ condus convingător pe actori şi a construit excelent mai toate momentele spectacolului. Nu e uşor să vorbeşti atât de limpede despre alegeri de viaţă, despre cum e bine să trăieşti şi cum să fii tu însuţi, evitând o lume şi o existenţă planificată (leitmotivul spectacolului fiind „Cum poți să-I faci pe Dumnezeu să râdă? Povesteşte-i planurile tale"). Dar Felix Crainicu reușeşte să pună corect şi accentele dramatice şi pe cele comice, semnând un spectacol conectat la contemporaneitate, echilibrat, mişcător şi pe alocuri jucat chiar excepţional - mai ales în unele scene dintre Star (o aşteptată, excelentă, revenire face actriţa Ela lonescu, pe care teatrele ar trebui să se bată) şi Jeff (Lari Giorgescu).

\section{Debut with hippies and retrocession. And two names to be remembered: David Schwartz and Felix Crainicu} concise analysis of two young directors' performances that are presented in Debut section of Romanian National Theatre Festival 2009. If director David Schwartz proves to have "an unexpected maturity and an excellent intuition in choosing the subject and contemporary tools to express it", Felix Crainicu tells a love story during hippie movement gathering a good casting". "Despite their true qualities, the directors and the young actors mentioned above can only be seen in the underground scenes of Bucharest, but not on the big stages that need so much the freshness of their point of view together with their talent and their enthusiasm."
Cristina Modreanu gives a 


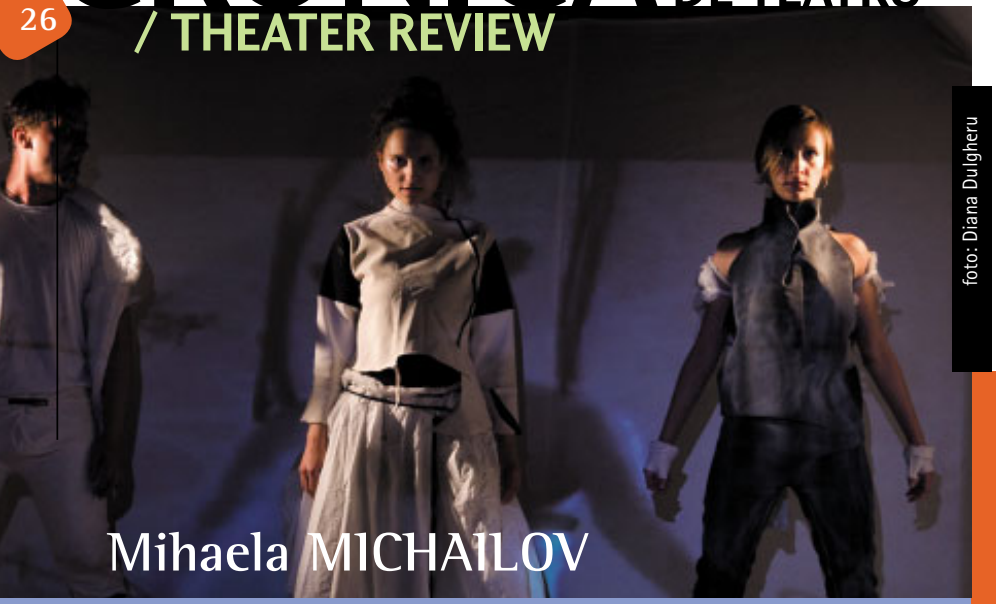

Pui camera pe moarte şi dup-aia înghiți hălci din personaje celebre într-o arhivă mortală.

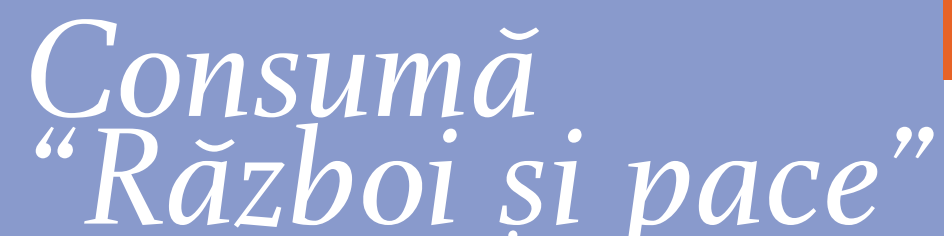

\section{sau arta - tampon al morții}

Există spectacole pentru al căror demers ar trebui inventat un limbaj critic adaptat conceptului propus, pentru că altfel analiza lor este inutilă şi neporductivă la nivelul receptării pertinente. Este cazul celor două montări ale lui Alexandru Mihăescu, unul dintre puţinii regizori români tineri care investighează formate dramaturgice nonliniare, hipersegmentate, în care narativitatea privilegiază flash-ul faptic. În „pool (no water)" de Mark Ravenhill (Teatrul German de Stat Timişoara) şi în "Concreţii" de Vladimir Sorokin (Teatrul LUNI de la Green Hours) se vorbeşte strâns, dens, în particule sonore care transpun o realitate sintactică din viitor, în coloane verbale fracturate, în imagini şi senzaţii care acţionează virulent. Ambele performance-uri explorează un teatru cinic-cinematic. Un teatru în care moartea face cel mai tare rating şi devine show-ul invadat de obsesia hipervizibilităţii - „pool (no

\section{Eating slices of „War and peace” or the art as death buffer - Monday Theatre at Green Hours}

"There are some shows for which one should invent a critical language adapted to the concept, because otherwise one's analysis becomes unuseful and unproductive on the level of relevant understanding. This is the case of the two performances signed by Alexandru Mihaescu, one of the few young Romanian directors that investigate nonlinear dramaturgical formats, hyper segmented where the narativity privileges the facts flash." Mihaela Michailov continues speaking about "Pool (No Water)" by Mark Ravenhill and "The Concretes" after Vladimir Sorokin, the first two performances directed by Alexandru Mihaescu included in the Debut section in 2009 Romanian National Theatre Festival. Therefore, the theatre critic Mihaela Michailov makes a concise analysis of the young director's manner of working, stating: "The two performances explore a cynic-cinematical theatre."

water)". Un teatru în care post-umani cu un design cyborg - "Concreţii" mâncători de ficţiuni rămase printre dinți. Personajele se distrează literaturii universale. Violenţa ficţiunii asupra fictiunii sau cum să hăcuiești agresivă dintre naraţiunile viitorului, cam aşa s-ar putea sintetiza lum
din „Concreții". „Concreţii" duce mai departe conceptul de lucru din "ptructura jocului actoricesc un tip de performare clinică, viscerală, asumată către actori

Marius Damian).

un proiect de cercetare regizorală a teatrului transgenic, cinematic (în artişti vizuali-creatori de concepte video: Levente Kozma - „pool..." şi Cinty lonescu - „Concreţii"), care

\section{.}

\section{"imar} "Cinematic Theatre, Scarecrow Press, 2004). Cuvântul performează la fel de puternic ca un sunet psihedelic sau ca o găleată de vopsea care mânjeşte sub ochii spectatorilor pereţii artei albe. Raportarea la mutilare ficţională (personaje care devorează în draci alte personaje - „Concreții") şi la ficţionalizarea mutilării (o artistă care-a căzut în piscină este filmată în stare de comă de către prietenii ei care intenționează să expună materialul filmat într-o galerie - „pool (no water)") apropie tematic cele două performance-uri. Piesele lui Mark Ravenhill sunt chirurgii ale maturizării, tăieturi adânci în epiderma inocenţei, exfoliată până la ultimul strat de vis. Personajele dramaturgului britanic, inclus în curentul devenit deja casic, „In-Yer-Face Theatre", teoretizat de Aleks Sierz, trăiesc într-o stare de permanentă urgență: socio-politică, artistică, intimă. Scriitura lui Mark Ravenhill este corporadicală, anarhic senzorială, expusă unui vertij afectiv, unei dorinţe furioase de a simţi ceva, orice, de a experimenta surfing-ul în totul sau nimic. 0 scriitură (Shopping and Fucking, The Cut, Some Explicit Polaroids, Product) care absoare prin toate venele şi porii cuvintelor confesiunile-blog ale unor "copii" ai suferinţei brute, dependenţi de adrenalina durerii. În „pool (no water)", Alexandru Mihăescu ia pulsul unei textualităţi decupate secvenţial, monologale, acumulate printr-o succesiune de mitologii personale.

0 gaşcă de prieteni, o comunitate de artişti burduşită de seducţia succesului şi de frustrarea eşecului îşi consumă invidia şi face tot ce-i stă în putinţă ca să testeze secunde de glorie, indiferent care e preţul lor. Trăiești doar dacă ești văzut, doar dacă ți se vând ultimele clipe de viaţă în prime time sau dacă faci din comă o instalaţie, par să spună artiştii. Textul este asimilat organic, rostit frontal de actori (Christine Cizmaş, loana lacob, Ramona Olasz, Horia Săvescu, Radu Miodrag Vulpe), cu un temperament performativ sangvin, arzând etapele de evoluţie tradiţională ale personajului şi tematizând convulsiv o atitudine, un tip de reacţie civică şi de dezbatere publică. Actorul este în acest tip de performance un actant al societăţii spectacolului cotidian, un creator reflexiv. Mihăescu asamblează compact, fără stridenţe sau edulcorări, un performance în care fizicitatea mişcărilor sparte, sincopat-violente şi a cuvintelor-jet, ţâşnite din corpuri în alertă, demonstrează o gândire contemporană a spectacolului. Vria informaţională şi comentariul asupra ei se integrează perfect în plasa lui de adâncime.

Nimic nu scapă camerei, hărţuirii ecranului global, care adulmecă habotnic, cu aceeaşi bulimie de senzaţional, viaţa şi moartea. În „Concreţii”" (Sorokin inventează particule lingvistice pentru un dicţionar al viitorului), arhiva este un un fel de abator high-tech în care trei tineri hiper mega marcaţi intră în sevraj fiç̧ional şi mănâncă maţe de vedete livreşti. Suntem în burta unei ficţiuni hrănite din intestinele iconurilor literare. 


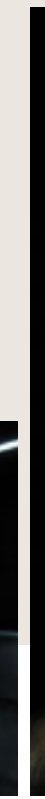
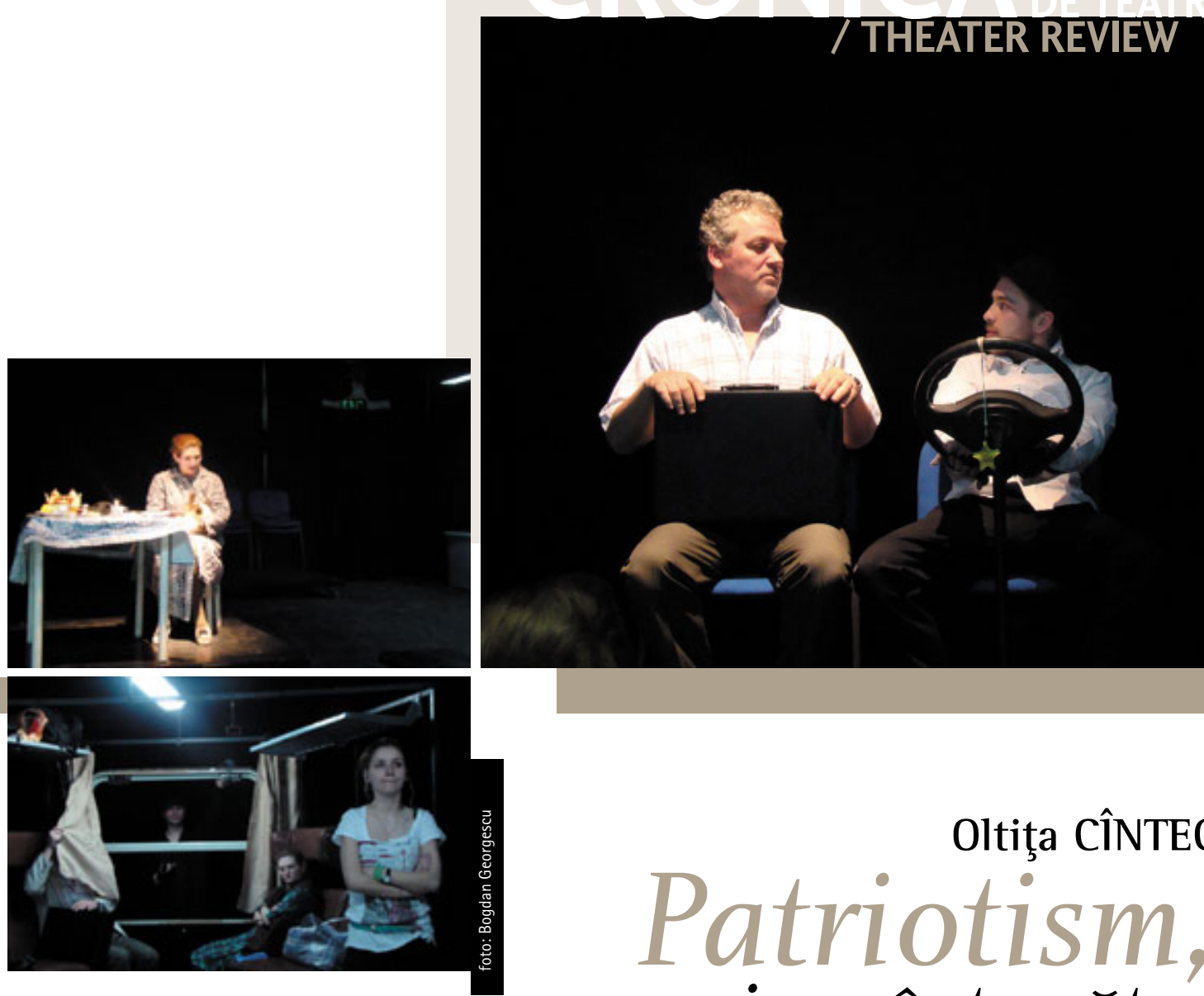

\section{Oltiţa CÎNTEC Patriotism,
cu miros întepător
dé ceapă}

Realizatorii spectacolului „România! Te pup" (de Bogdan Georgescu, regia David Schwartz, scenografia Adrian Cristea), la sala Uzina cu Teatru a Teatrului Naţional „Vasile Alecsandri” din laşi, sunt artişti tineri care explorează declarat, adesea ostentativ, noile forme de teatralitate. Bine fac! Spectacolul teatral s-a hibridizat în ultimele decenii, activându-şi mai mult ca niciodată mecanismele sincretice, producând formule de graniţ̧ă, preluând şi integrând organic mijloace de expresivitate străine lui ca gen până mai ieri. Piesa „România! Te pup" are o istorie: redactată, în 2004, într-o versiune de câteva file, undeva în Bistriţa, în cadrul unui workshop, a fost tipărită în câteva antologii bilingve, prezentată ca spectacol-lectură şi ca punere în scenă la New York; pentru versiunea ieşeană, Georgescu a dezvoltat-o împreună cu echipa, inclusiv distribuţia, pentru a-i asigura formă ieşeană.

Piesa are un story animat de trei personaje: o tânără pregătită să plece la studii "afară", pe care o cheamă, ei, da, „Vasile" (Andreea Boboc), "Miss Renata" (Georgeta Burdujan) şi „Domnul Neagoe” (Teodor Corban), genul care nu ezită să se descalţe în tren, ca să se simtă comod, acum băgat într-o afacere nu tocmai curată. Se întâlnesc într-un compartiment de accelerat de noapte - of, trenurile noastre! -, ţin nepărat să-şi împartă dreptatea pe chestiuni mărunte, apoi, prinşi într-o situaţie tragică, dau bir cu fugiţii. Nu au nimic eroic, sunt personaje mărunte, prinse în pânza de păianjen carpato-danubiano-pontică. Bogdan Georgescu are simţul teatralului, istorioara spusă scenic mustind de românism prin grotescul ei tragicomic-absurd. Patria e înfăţişată necosmetizat, cu tarele şi viciile celor care-o populează.

Planul narativităţii e completat şi intersectat de un altul, acela în care un grup de interpreţi, pe post de cor, realizează un comentariu metateatral, nonverbal, refăcând aerul (deloc ozonat) de România, din fum de ţigară, miros de ceapă tocată, pateu de ficat la cutie metalică, bere. Spectatorii, mai ales aceia din primele rânduri, sunt agresaţi olfactiv, poate şi vizual, dar acesta e şi scopul, recrearea scenică a senzaţiilor de Românie autentică. Spaţiul sonor e invenţia lui Bobo Bogdan Burlăcianu, care I-a conceput folosind ingenios sunete reale, naturale, live, obţinute de grupul de figuranţi (Clement Alexandru Arnăutu, Florin Caracala, Biatrice Cozmolici, Mirela Nistor, Vlad Wolf) din pahare, sticle, mături, cutii, răzătoare etc. Secvenţele muzicale impun tempoul spectacolului, cam lent la debut, dar maşinăria scenică se ambalează pe parcurs, căpătând un ritm potrivit. Ingenioasă a fost şi ideea scenografică, de segmentare a spaţiului în platforme mobile de joc, aranjate şi rearanjate în funcţie de centrul de interes spectacular. Totul e la vedere încă de la început, inclusiv actorii, şi la vedere rămân până la final. Asta urmăreşte şl proiectul, să nu ascundă nici un adevăr despre România. Pe care o pupăm.

\section{Patriotism with onion smell - „Romania! 1 kiss you", National Theatre from lasi}

Oltiţa Cîntec considers „Bogdan Georgescu has a feeling for theatre, as the little story told by him on the stage is rich in Romanian characteristic and deeply related to tragic-comical-absurd. The Homeland is seen without any garnishments, with all the imperfections and vices that defines it." In fact this is the key of the show "Romania! I kiss you" by Bogdan Georgescu, directed by David Schwartz and produced by National Theatre from lasi. They are "young artists that openly explores, often ostentatively, new forms of theatricality. Good for them! The performance in theatre was hybridized in the past decades, activating more then ever its syncretic mechanisms, producing bonding formulas, taking over and integrating tools of expressivity. 



\section{Opera Revival - Tradition versus innovation}

Orfeu and Euridice, Evgheni Oneghin and The Fantastic Simphony are the other three creations included in this year's new section of RNTF: Opera Revival. These productions are characterized by the presence of theatrical and dance methods as we encounter here the work of famous directors and choreographer: Alexandru Darie, Ion Caramitru and Gigi Caciuleanu. About "The Fantastic Symphony", Andreea Chiselev observes: "The performance is an excellent combination of classic and modern, of theatre and dance, with impressionistic notes or surrealistic ones, having as central focus the loneliness and the two sided symbol of the mirror."

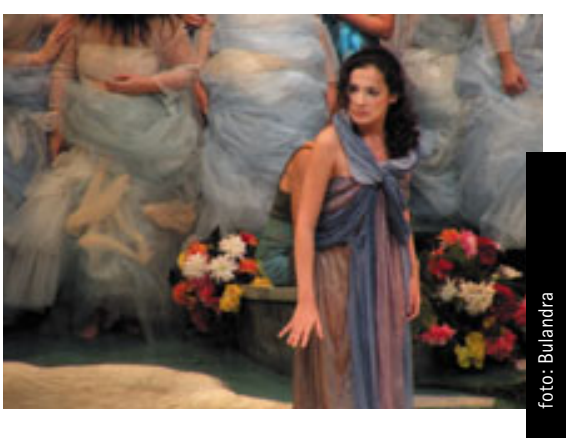

La Teatrul Bulandra vom putea vedea o sinteză modernă între teatru, dans şi muzică - variaţiuni pe teme de Gluck, semnate Adrian Enescu. La întrebarea: prin ce se evidenţiază montarea actuală cu „Orfeu şi Euridice" faţă de una tradiţională, răspunsul ar fi, într-un singur cuvânt, complexitatea. În opinia lui Alexandru Darie, ne aflăm în faţa celui mai dens şi "greoi" spectacol regizat de el, totodată "cel mai frumos dintre toate". Ornamentaţia barocă este evidenţiată de scenografia lui Octavian Neculai (în timp ce decorul apare ca un templu, semnificând călătoria în timp), completată de o notă abstractă a proiecţiilor video (Daniel Gontz) şi opulenţa costumelor. Dominantă în spectacol este ideea de bipolar, simultan opus şi complementar, yin şi yang: fiecare cântăreţ solist (suflet) este dublat de un actor (trup). Montarea proiectează în contemporaneitate o poveste despre triumful dragostei - „dragostea ca forţă invincibilă" (Alexandru Darie) - ce reuşeşte să surprindă. Veţi fi cu siguranţă captaţi, poate contrariaţi de modernitate şi interesaţi de colaborarea inedită a unei echipe atât de numeroase: actori (printre ei - Dana Dogaru, Camelia Maxim, Manuela Ciucur, Iuliana Ciugulea, Claudiu Stănescu), solişti ai studioului experimental de operă şi balet "Ludovic Spiess" din cadrul Operei Naţionale Bucureşti (Florentina Onică, Marta Cristina Sandu, Claudia Deleanu), Orchestra Metropolitană de Cameră (dirijor Tiberiu Soare) şi corul Accoustic (dirijor Daniel Jinga).

\section{OPERA}

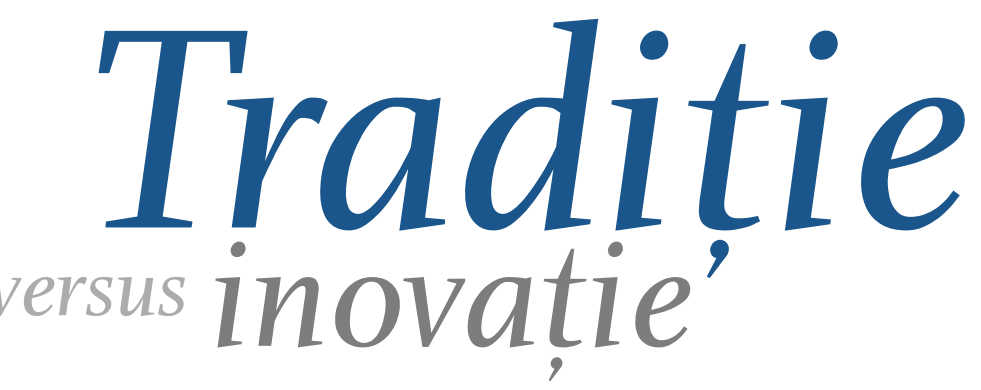

Seria Opera Revival - spectacole muzicale în viziunea unor regizori de renume - propune, cle două opere de Giuseppe Verdi, "Macbeth" si "Otello", alte trei reprezentatii scenice, cu „Orfeu şi Euridice”, „Evgheni Oneghin” şi „Simfonia fantastică”.

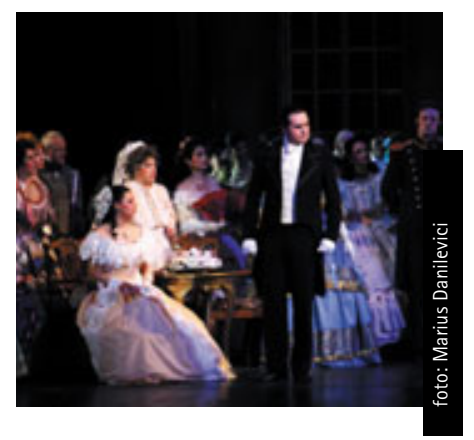

0 viziune total diferită despre un spectacol de operă are lon Caramitru, în „Evgheni Oneghin" de Ceaikovski (după romanul în versuri scris de Puşkin). Regizorul optează pentru îmbinarea dintre tradiţional şi modern, fiind interesat de un „spaţiu metafizic, de vis, pornind de la obsesia lecturii care o bântuie pe Tatiana, făcând-o să se desprindă de real. De aici, din scriitura regizorală, rezultă componenta modernă a spectacolului" (Ion Caramitru). Se remarcă nota cinematografică a desfăşurării acţiunii, în care regizorul a introdus un alter-ego al Tatianei, o fetiță ce simbolizează inocența, ce apare ca prin vis în momentele cheie. Spectacolul prinde viaţă prin balurile fastuoase imaginate, decorurile Mariei Miu, costumele deosebite ce păstrează atmosfera epocii ale Vioricăi Petrovici sau concepţia regizorului de lumini Chris Jaeger. Totul se potriveşte ca o mănuşă lirismului de tip romantic al operei. Nota tradiţionalistă cu accent pe intensitatea trăirilor personajelor ne transmite o atmosferă plină de rafinament, 0 amintire a Rusiei de secol XIX. După versiunea iniţială, semnată de Ion Caramitru acum 14 ani, în Irlanda, publicul românesc are ocazia să vadă şi să asculte acest "Evgheni Oneghin" în cadrul Festivalului Naţional de Teatru, la Opera Naţională Bucureşti, sub bagheta lui lurie Florea.

\section{Andreea CHISELEV}

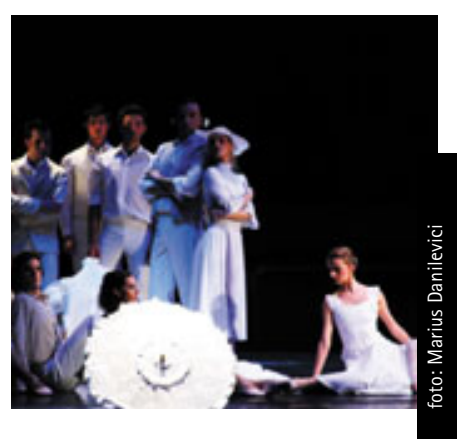

V-aţi întrebat probabil de ce am numit "Simfonia fantastică" de Hector Berlioz "spectacol". E pentru că îi datorăm lui Gigi Căciuleanu o reinterpretare a acestei partituri muzicale, pe texte de Molière, Shakespeare, Baudelaire, Verlaine, Rostand. Este vorba de un teatru coregrafic, ce porneşte de la muzica lui Berlioz dar propune o poveste proprie a creatorului, "o Simfonie fantastică de Gigi Căciuleanu", după cum menţionează acesta. Sensurile partiturii sunt investigate şi reinterpretate, într-o simbioză a dansului, poeziei, muzicii, teatrului, pantomimei, artelor plastice, luminii, tăcerii. În rolurile principale - cunoscutul dansator Răzvan Mazilu (un adevărat „balerin-actor"), Bianca Fota (plină de graţie în întruchiparea iubitei), sau Dan Puric (actor, mim şi dansator). Scenografia este semnată de Adriana Urmuzescu, iar conducerea muzicală de Tiberiu Soare. Spectacolul este o îmbinare reuşită între clasic şi modern, între teatru şi dans, cu note impresioniste sau suprarealiste, având ca repere centrale singurătatea, căutarea sau simbolul dual al oglinzii. 


\section{MiHAELA MICHAILOV}

\section{Corpul convenţiei}
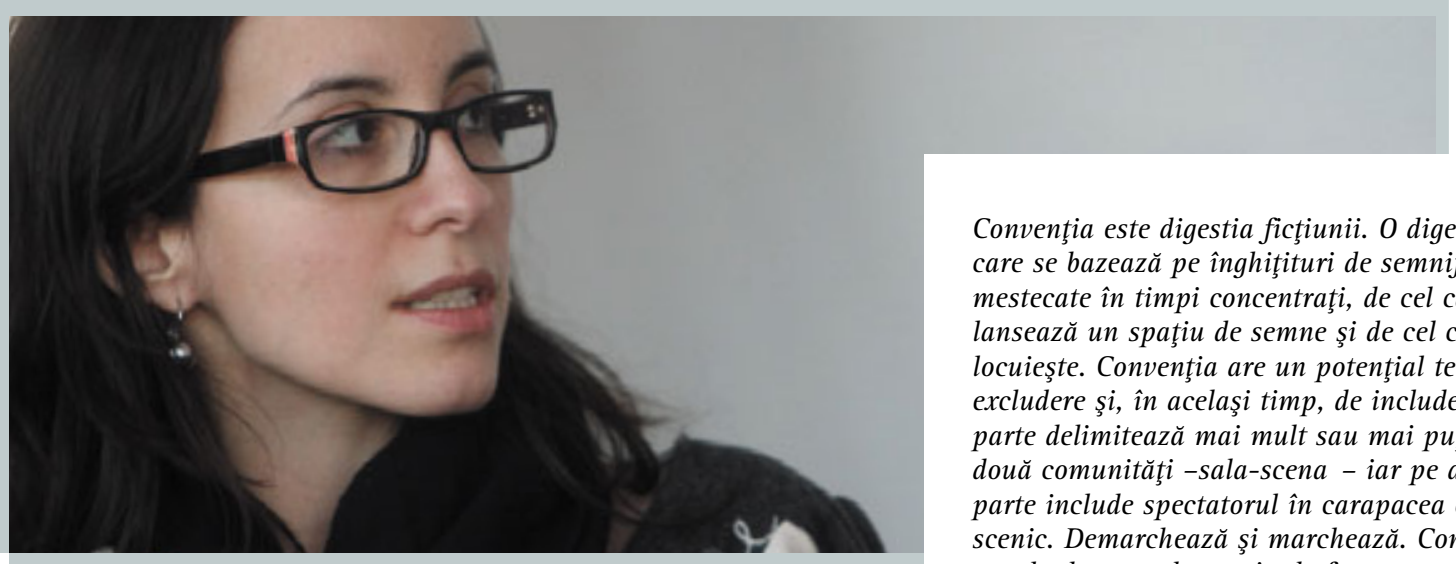

În "Surfing twisted (e)motions", repetiție deschisă prezentată în cadrul Platformei Dansului Contemporan - „Băi, efemerule!" (17-20 septembrie), Mihai Mihalcea concepe o comunitate de interval estetic şi politic, aţâţată de impulsuri novatoare şi căptuşită cu material tradiţional. 0 comunitate pe sfoara fragilă dintre fotă şi mouse, dintre păpuşele vechi şi pistoale şmechere, în care tot ce se insinuează este, la început, o jucărie haioasõ care-ţi poate zbura în orice secundă creierii. În această comunitate seducător retro, războiul mătură tot.

Primul gest făcut în scenă este unul de marcaj. 0 aţă este rulată ca un cordon ombilical al convenţiei, cronometru vizual care bate ceasul ficțiunii. Cele cinci dansatoare - Mădălina Dan, Maria Baroncea, Carmen Coţofană, Alexandra Pirici, Cătălina Gubandru - îşi implantează celule de subiectivitate în miezul recuzitei convenţionale. Se mişcă simultan, după o dramaturgie improvizată individual cu un schelet comun recognoscibil. Fiecare îşi delimitează rama spaţială şi îşi aşază obiectele-semne ale unui timp care nu ţine multă vreme. Cam cât textul înregistrat, extras din „Principesa Martha Bibescu - mare pianistă" de C.D. Zeletin, care vorbeşte despre stropii de modernitate din Vest picuraţi peste matricea orientală. 0 lume este despăturită, pentru ca la final, după ce i-a fost ameninţ̧ată organizarea politică, morfologia statală şi identitatea comunitară, să fie despăturită, strânsă şi luată la pachet. Convenţia fuge din scenă, uşuind guvernul politico-estetic instalat pentru o scurtă perioadă. "Surfing twisted (e)motions" pare o joacă între fetiţe cu peruci, care-şi strâng armamentul ludic şi se cară. E însă mult mai mult decât atât. $E$ un performance cu potenţial politic. Gunoiul are clipa lui magică, ochiul lui de iluzie trează, momentul de trambulină afectivă.

În spectacolul Mariei Baroncea

- „Fantasy Show Made out of Trash" -, magia ţâş̧neşte din burta fierăriei. Se caţără şi devine pană albastră. Baroncea împinge în scenă o schelă
Convenţia este digestia ficţiunii. 0 digestie rapidă care se bazează pe înghiţituri de semnificaţii mestecate în timpi concentraţi, de cel care lansează un spaţiu de semne şi de cel care $\hat{\imath} l$ locuieşte. Convenţia are un potenţial teatral de excludere şi, în acelaşi timp, de includere. Pe de o parte delimitează mai mult sau mai puţin explicit două comunităţi -sala-scena - iar pe de altă parte include spectatorul în carapacea codului scenic. Demarchează şi marchează. Convenţia este parola de acces la un tip de format performativ care functionează prin absorbţie: o întreagă existenţă sau o felie de istorie este înghițită în parametri temporali ai câtorva ore. Ea activează un sistem de semnalizare scenică butonat la două mâini: creatorul ei îi dă un click şi receptorul ei un dublu click. Spectacolul este un parteneriat activ în care termenii convenţiei sunt negociaţi la cald, cu toate antenele senzoriale puse la bătaie.

pe care sunt aşezate reflectoare. Coregrafa agaţă convenţia şi-o cară după ea, ca şi cum i-ar fi soră tehnică. Aduce mecanismele schemei teatrale la câţiva metri de spectatori, care dau cu ochii de hard disk-ul facerii, de tot ce pune în fermentaţie maţele unui spectacol, de tot ce nu ni se pare destul de important ca să fie văzut.

Cu o candoare pe care o explorează în fiecare performance şi cu un ataşament tandru faţă de spaţiul concret sau fictiv, Maria Baroncea creează oraşe de subiectivitate cu epicentrul într-un vârf de vis. Există o textură specifică spectacolelor sale, amestec de elemente palpabile şi miez straniu-halucinant. Solo-urile Mariei Baroncea degajă un tip de emoție inocentă, venită din vulnerabilitatea şi libertatea unei coregrafe care ştie să combine perfect neîndemânarea intenţionată cu elaborarea lipsită de artificialitate. Prezența unor detalii obiectuale din registre diferite, dar, conceptual, gemene - sârmuliţe, device-uri şi pene - dau spectacolului un nivel secund de semnificare. Baroncea accesează nivele de convenţionalitate diferite. Cuplează accesoriile de tehnică şi accesoriile de magie, şuruburile care fac un spectacol să fie ceea ce este şi penele care-i dau glamour-ul seducător. Întotdeauna coregrafa urcă un gest, o mişcare, un sunet şi le face să-ţi devină coloană mentală, fundal care ţi se reactivează mereu.

\section{Convention in dance} second one "Fantasy Show Made out of Trash" choreographed by Maria Baroncea, being "a mix of touchable elements and a strange- hallucinogenic core". 


\section{Eugen lonescu, scriitor român minor}

Voci de calibru s-au ridicat, indignate, comentând negativ decizia fiicei lui Eugène lonesco de a regla în mod formal modul în care figura scriitorului este utilizată în spaţiul cultural românesc. Dar dacă am încerca să nu mai luăm lucrurile atât de personal, desprinzându-ne de paranoia seculară şi am înceta câteva clipe fie să ne autoflagelăm, fie să ne împăunăm cu merite şi talente ieşite din comun? Dacă ne-am privi, aşa, sub formă de experiment antropologic, ca ceea ce suntem, nimic mai mult, dar nici mai puţin, identificândune problemele reale, ca civilizaţie şi dezvoltare culturală? Fără să ne înjurăm, dar şi fără să ne genializăm? Atunci poate că, emoţia unui permanent atac la efigia noastră culturală naţională fiind anulată, raţiunea ne-ar arăta că Marie-France lonesco are îndreptăţirea de a vorbi în numele tatălui ei.

Căci, tot raţional vorbind, sunt puţine şanse ca lui Eugène lonesco, dacă ar putea vorbi, să-i placă ceea ce se întâmplă acum cu numele lui, în teatrul românesc. Nu cred că vreunui autor dramatic, indiferent de calibrul său (şi cu atât mai puţin lui lonesco), i-ar plăcea să fie numit "cacialmist" şi să se dea de înţeles că se face o concesie dacă i se montează nişte texte..., nu cred că undeva în lume acest lucru i s-a mai întâmplat lui Eugène lonesco, nu cred că acceptarea se face prin înjosire şi apoi prin adulare... şi realmente nu cred că mai există vreun loc în lume unde e de la sine înţeles faptul că regizorul se foloseşte de piesa de teatru, în loc ca aceasta să-i fie de folos. Ceea ce, în mod logic, defineşte actul regizoral - de acest tip - ca fiind imoral. Dar, revenind la fapte, dacă acordăm prin lege dreptul unui om de a se numi aşa cum vrea el, de a-şi declara formal naţionalitatea pe care o simte ca fiind a lui, religia şi chiar sexul pe care, mai nou, şi-I poate schimba, de ce nu i-am recunoaşte acest drept lui Eugène lonesco, autor dramatic francez de origine română? E drept, lonesco vorbea româneşte şi a scris în România, sub numele Eugen lonescu, dar opera sa de autor dramatic este produsul unui climat şi al unui context care i-au permis să se dezvolte. În România şi scriind în româneşte, Eugen lonescu a fost un scriitor român minor. Plecând din România, Eugène lonesco a ales - ceea ce presupune, neapărat, şi o renunţare. A ales să nu mai fie un scriitor român minor şi să devină un important autor dramatic francez. Pe cine vrem noi să serbăm? Un scriitor român minor - ar fi nedrept pentru ceilalţi scriitori români mai importanţi decât Eugen lonescu. lar scriitorul francez nu este creat în context cultural românesc, aşa că serbările pe seama lui, dincolo de penibilul encomiastic, au un aer suspect, de impostură. În Parisul mijlocului de secol douăzeci, în care emulaţia artistică creează mediul de dezvoltare a unui fenomen ce va fi numit teatrul absurdului, „micul imigrant român", cum îl numeşte Martin Esslin pe Eugène lonesco, va deveni un mare scriitor francez. Dar nicidecum un mare scriitor român. La fel cum Adamov este un scriitor francez de origine armeană, iar Tom Stoppard - scriitor britanic de origine

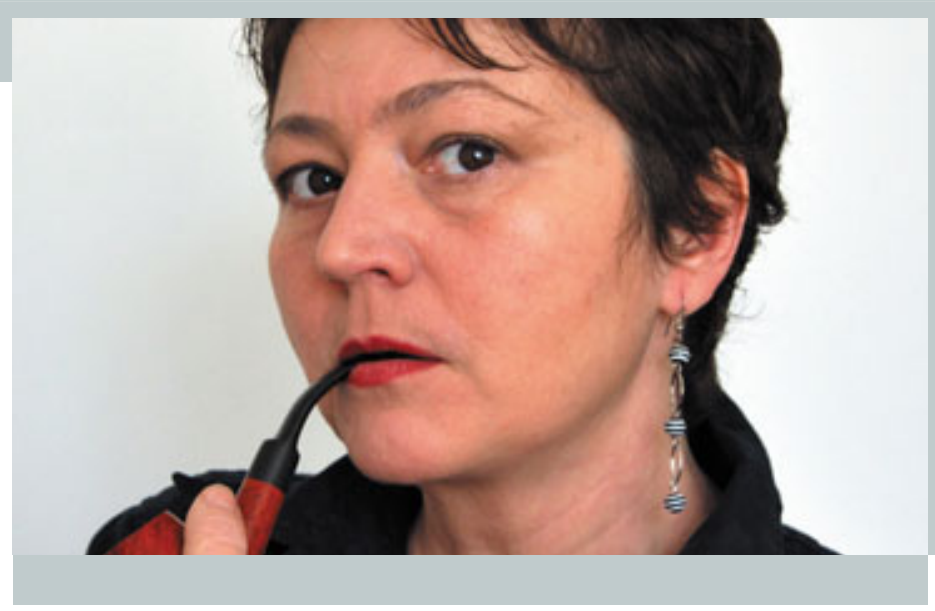

cehă. Nu am auzit vreodată ca Tom Stoppard să fie considerat scriitor ceh, căci el a scris şi s-a dezvoltat ca autor dramatic în lumea anglofonă. În ce-i priveşte pe armeni, nu am fost niciodată la Erevan, dar nu cred că e plin pe-acolo de statuile lui Adamov. Revenind la destinul şi deschiderile lui lonesco pe vremea când trăia în România şi se numea lonescu, îndrăznesc să presupun că, dacă ar fi continuat să scrie şi să-şi ducă viaţa aici, ar fi ajuns, poate, să-i regizeze "Cântăreaţa cheală" la Slatina, Nicu Georgescu, profesorul de română şi directorul casei de cultură din localitate şi nu ar fi ajuns niciodată să fie montat la Théâtre de la Huchette, Comedia Franceză, Teatrul Royal Court sau pe Broadway. E posibil să fi ajuns să cerşească bunăvoinţa d-lui Dumitru Popescu sau, poate, să deschidă polemici cu dl. Paul Everac, şi nu cu Kenenth Tynan. Sau, cine ştie, poate ar fi fost bun prieten cu dl. Ion Băieşu şi cu dl. Marin Sorescu, nu cu Nicolas Bataille şi Armand Salcrou. Ar fi scris, poate, despre piesele lui, dl. Valentin Silvestru şi nu Martin Esslin. Sau, subteran, aranjând scaune în sala profesorală, ar fi reuşit să-şi învingă chinul şi frustrarea şi să organizeze un festival de teatru şcolar în limba franceză unde, spre oroarea şi invidia colegilor, să aibă şi el mici texte cacialmiste montate cu elevii săi preferaţi. Oare mai existau şi alte opţiuni în cultura română pe vremea când lonesco era montat peste tot în Europa şi America, pe vremea când era făcut membru al Academiei Franceze?

Atitudinea d-nei Marie France lonesco este poate, pentru unii, extremă. Dar este dreptul d-sale, legal şi moral. lar a-ţi atribui merite pe care nu le ai, a-ţi asuma lucruri care nu ţi se cuvin, a te împăuna cu o imagine sau o efigie care nu te reprezintă - acestea sunt nedemne de o cultură europeană, cum am vrea să fim receptaţi, în primul rând noi de către noi înşine. Ce-ar fi, la urma urmelor, să fim fericiţi că Eugen Ionescu a rămas un scriitor român minor şi să-i lăsăm lui Eugène lonesco ceea ce şi-a luat singur, respectiv calitatea de scriitor francez, poarta prin care a intrat în universalitate?

\section{Eugen lonescu, a minor Romanian writer}

Eull of indignation, famous voices have been heard, negatively commenting upon the decision of Eugene lonesco's daughter to set the way in which the Friter's name is used in Romanian cultural space. But what if we can take a look to ourselves the way we are, and identify our real problems, in terms of civilization and cultural evolution? Then maybe we will see that Marie-France lonesco is right to speak on behalf of her father, Alina Nelega argues: "It is true, lonesco was speaking Romanian and wrote in Romanian, under the name of Eugen lonescu, but his work as a playwright is the product of a climate and context that permitted him to develop. While in Romania, writing in Romanian language, Eugen lonescu was a minor Romanian writer. Leaving Romania, Eugène lonesco made a choice. This is by all means a renunciation. He has chosen not to be a minor Romanian writer and to become an important French playwright." 


\section{NINSORILE}

\section{Turandot, like a crazy dream}

Mirella Patureau creates a short but important history of three Vroductions of "Turandot Princess" by Carlo Gozzi: the one directed by Lucian Pintilie in the 70's, the second that she will see this autumn in Romania with the occasion of Romanian National Theatre Festival 2009, the new production from Sibiu staged by Andryi Zholdak, and the third staged by Vakhtangov in 1922 in a cold Moscow just before his death. Mirella Patureau focused on the third production, this being "a fairy scene full of colors and grace", and she ends her article with an admiration note: "Turandot" by Vahtangov remains today as one of the brightest, the most colored and happiest pages in the history of universal theatre."
„Turandot" montat de Vakhtangov în 1922, feerie plină de culori şi de graţie, în plin război civil, într-o Moscovă îngheţată şi flămândă. Spectatori încotoşmăniţi ce aplaudă fără să-şi scoată manuşile şi strigă bravo cu voci răguşite de frig, nu vă aduc aminte de nimic, vouă spectatori români ai iernilor de acum mai bine de douăzeci de ani, veniţi să găsească la teatru căldura interioară a unei bucurii pe care nici o dictatură nu o putea îngheța? Repetițiile lui Vahtangov începuseră în 1920, premiera a avut loc în februarie 1923, căci Studioul condus de Vahtangov era o şcoală - laborator. Vahtangov montează feeria lui Gozzi, scrisă în 1762, reinventând la rândul său o commedia dell'arte, în spiritul timpului. Contemporanii săi, Meyerhold cu „balaganul" său teatru de bâlci, Tairov în căutările sale sofisticate de la Kamernyi Teatr, luaseră acelaşi drum. Cum arăta spectacolul, un fost elev îşi aminteşte: „Imaginaţi-vă, spunea Vahtangov, că vedeţi un actor intrând în scenă. Este eroul principal, ochii săi strălucesc de focul luminos al pasiunii, îşi spune monologul. Obrajii săi se acoperă de lacrimi. Nu le ascunde, plasându-se în fața publicului: vedeți cum plâng, cum sufăr... aplauzele izbucnesc de pretutindeni. Cu ochii plini de lacrimi, el prinde din zbor portocalele ce i se aruncă, trimite o sărutare pe vârful degetelor unei frumoase de la balcon, în fine, se aşază pe marginea scenei, cu picoarele balansându-se spre sală şi mestecând placid portocala privește jocul de pe scenă".2 Trebuie să vă imaginaţi această demonstrație exuberantă, plină de veselia înconştientă a tinereţii dirijată cu un curaj şi o energie eroică de un om de 38 de ani în fază terminală de cancer. Transportat de urgență acasă după repetiţia generală, Vahtangov nu a putut asista la premieră. Atmosfera e fabuloasă şi merită povestită: sala, plină de un public avizat şi complice, cade imediat sub farmec. După primul act, Stanislavski îi telefonează lui Vahtangov pentru a-I felicita şi fuge imediat să-i povestească direct succesul. Tot teatrul aşteaptă fremătând întoarcerea sa și spectacolul se reia în aceeaşi atmosferă delirantă. Marele actor Mihail Cehov, nepotul dramaturgului, strigă alături de ceilalţi spectatori: „Bravo Vahtangov!” Erau colegii cunoscători, presa şi o parte din oficialităţi strâmbă însă din nas, tratându-I de formalist, supremă insultă în pragul inventării realismului socialist. Spectacolul va continua însă triumfal cu o serie de turnee în Europa, din 1923 în 1927, de la Talin la Stochkholm, Berlin sau Paris. "Turandot" de Vahtangov rămâne astăzi una din cele mai luminoase, mai colorate şi mai fericite pagini din istoria teatrului universal. Prinţul învingător avea dreptate: „All'alba vincera!"

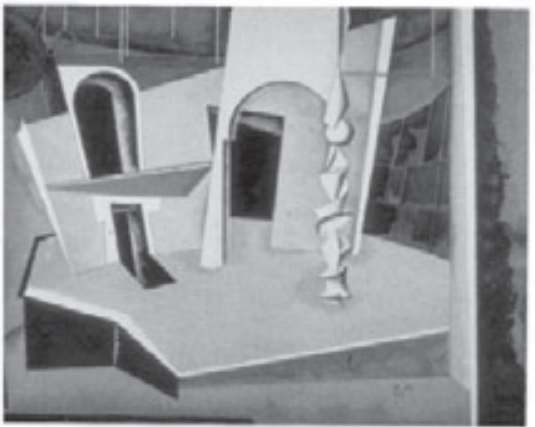

Schiță de decor, spațiul de joc, I. Nivinski, 1922

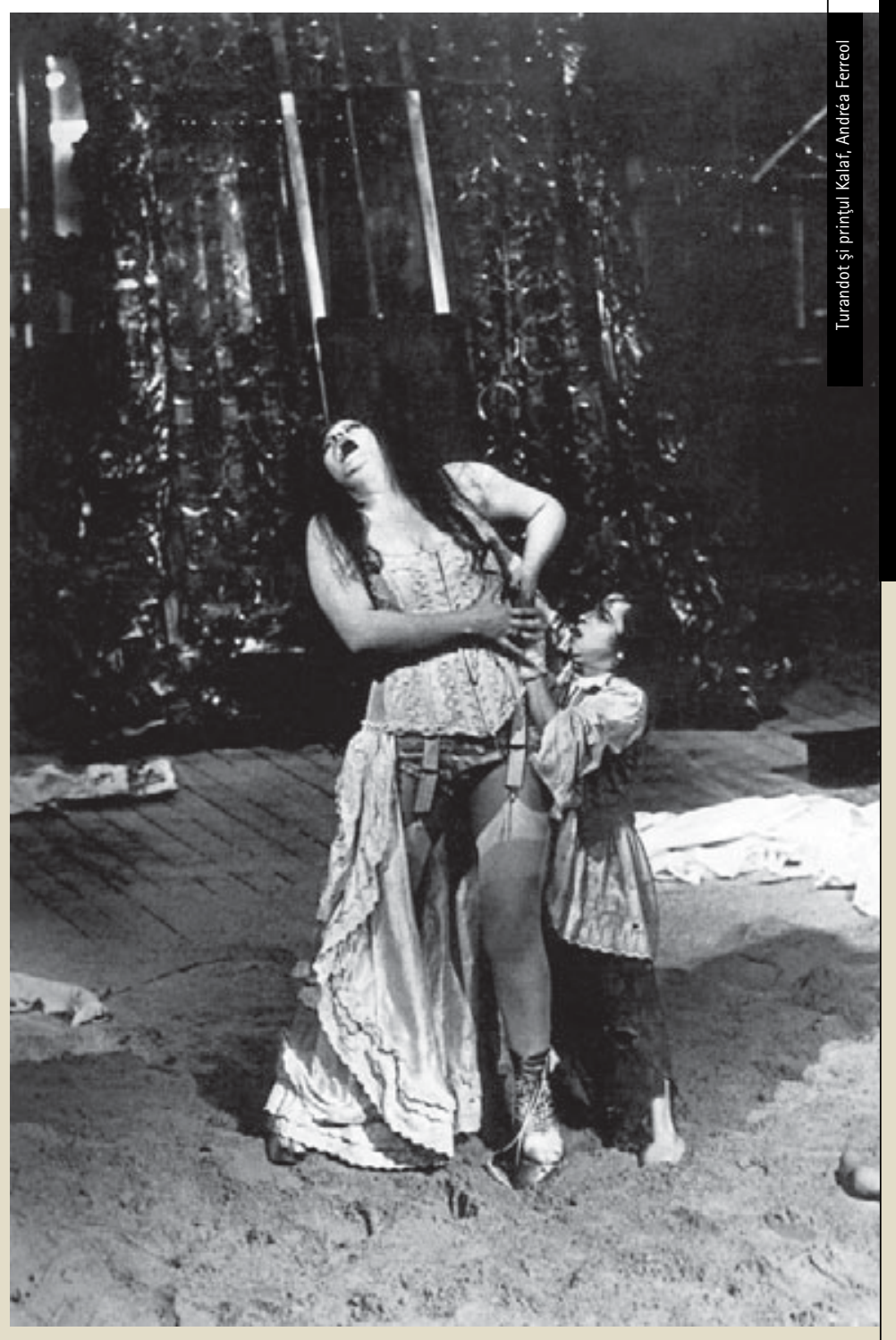

2 Boris Zakhava, "Evguéni Vakhtangov et son école" ("E.V. şi şcoala sa"), Editions du Progrès, Moscova, 1973. 

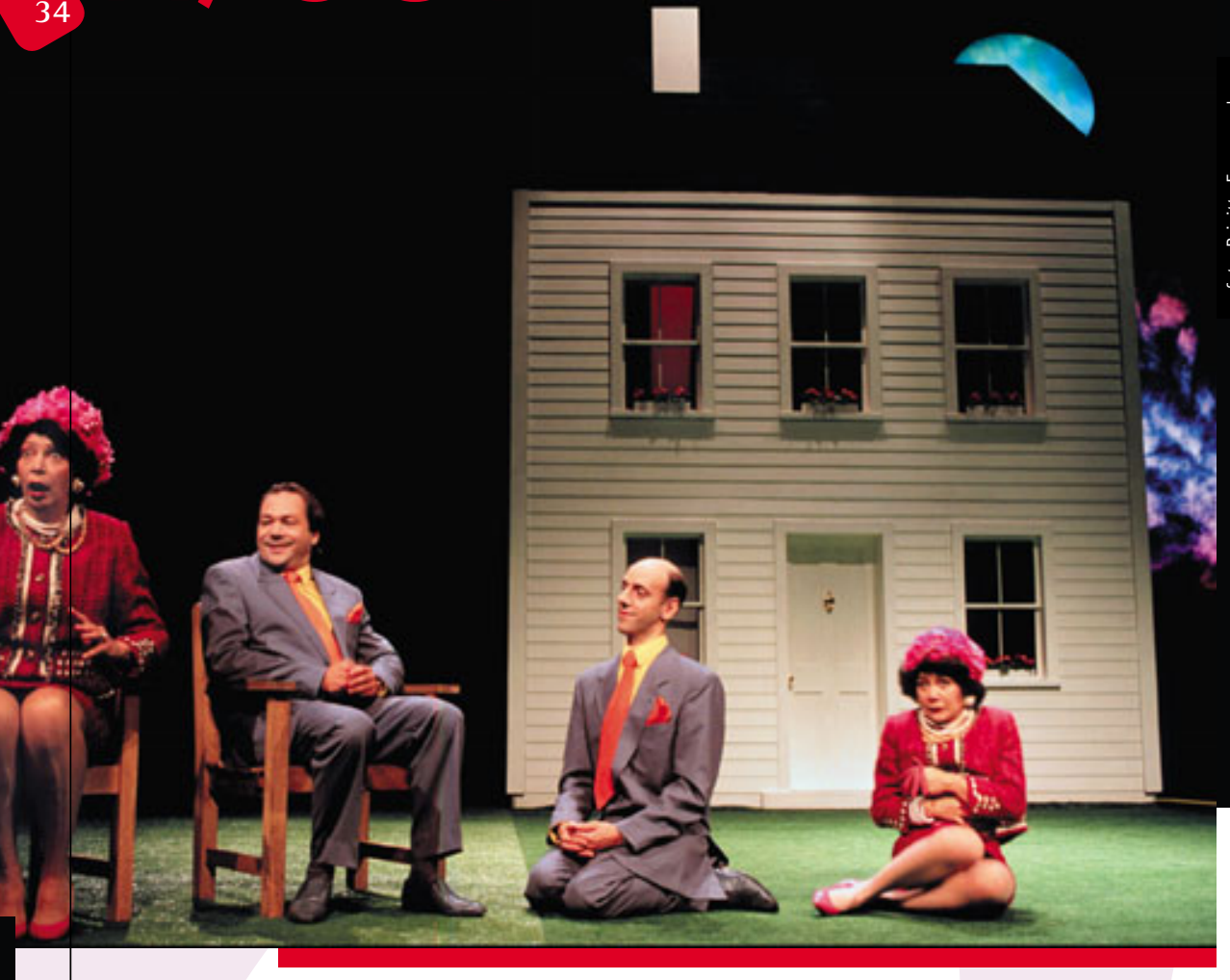

Mirella PATUREAU

„Le Pompier: A propos, et la cantatrice chauve? Mme Smith: Elle se coiffe toujours de la même façon!” ("Cântăreaţa cheală", anti-piesă, Scena X)

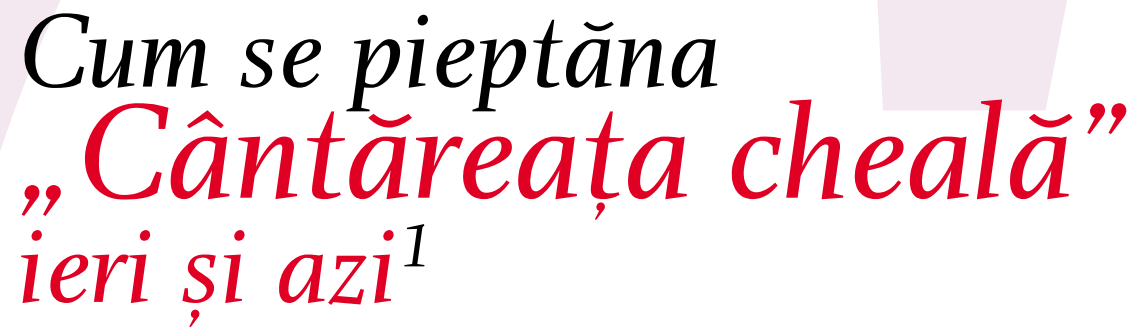

Nimeni nu ignoră astăzi debuturile furtunoase şi dificile ale piesei lui Eugen lonesco, mai întâi în 1950 la Théâtre des Noctambules, fost garaj reconvertit în sală de spectacol, astăzi dispărut şi în fine începând din 1956 la "cavoul" sau pivniţa de la Huchette, în inima Cartierului latin din Paris. Tot cum nimeni nu ignoră că piesa se joacă aici fără întrerupere până în ziua de astăzi, minuscula sală legendară devenită de acum un adevărat muzeu al teatrului de avantgardă a anilor '50. După insultele şi ne înţelegerile profunde al cărui campion a fost pe vremuri nefericitul critic de la Figaro ${ }^{2}$ , au urmat anii consacrării şi ai "clasicizării" incomodului dramaturg. Şi de aici roata a început iar să se învârtă, reproşându-i-se de astă dată căderea într-o altă tradiţie. Ionesco continua să fie jucat traversând toate acestea valuri, la modă sau împotriva ei şi fiecare generaţie descoperă fiecare un alt chip. În 1991, o tânără companie animată de regizorul dramaturg Jean-Luc Lagarce alege să se confrunte cu acest text fondator al "anti-teatrului contemporan" (cu mult înainte ca Hans Thies Lehman să inventeze "teatrul postdramatic"). Jean-Luc Lagarce este un dramaturg jucat şi, sper, cunoscut în România, graţie traducerilor Ancăi Rotescu şi spectacolului lui Radu Afrim cu „E doar sfârşitul lumii" şi nu mai e nevoie să amintesc aici datele sale biografice ca şi tragica sa dispariţie. Or, se petrece un fenomen interesant şi rar, la cincisprezece ani de la creaţ̧ia spectacolului şi la aproape zece ani de la moartea regizorului, interpreţii săi decid să reia spectacolul, exact cum a fost, păstrat în memoria actorilor şi cu decorul de la origină conservat în mod miraculos. Fenomenul e rar, dar nu unic, e gestul unei echipe, neconsolate, unite în jurul unui creator, răpit prea devreme de zeii geloşi pe noi bieţii muritori, pentru a-i păstra o parte din ce i-a unit odinioară. Aşa s-a întâmplat de pildă cu unul dintre cei mai interesanţi coregrafi francezi, Dominique Bagouet, dispărut şi el în 1992 de SIDA, ale cărui coregrafii au fost prezervate şi continuă să fie difuzate de membrii fideli ai companiei sale. Gestul e mult mai facil pentru un spectacol coregrafic, căci dansul clasic, ca şi baletul contemporan, pot fi notate, după o codificare proprie, ajutate astăzi de numeroase versiuni filmate. Pentru "Cântăreaţa cheală", există bine înţeles textul, declaraţ̧iile regizorului, fotografiile. Dar baza, după spusele actorilor, conduşi de un coleg devenit regizor François Berreur, care interpreta rolulul căpitanului de pompieri, a

' Piesa, pusă în scenă de Jean-Luc Lagarce în 1991, a fost reluată în 2006 la Théâtre de l'Athénée Louis Jouvet din Paris. După «anul Lagarce» în 2007, când regizorul, dispărut în 1995, ar fi trebuit să împlinească 50 de ani, au urmat o serie de turnee în Franţa şi străinătate, printre care FNT, Bucureşti în noiembrie 2009.

${ }_{2}^{2}$ Mult mai tîrziu, în pragul bă trâneţii, Jean-Jacques Gautier mărturisea cu tristeţe că ratase acest debut dar că de acum gustă din plin piesele acestui „fumist genial" (apud Pierre Marcabru)" , metec "dezrădăcinat"( vezi filozoful şi dramaturgul Gabriel Marcel)devenit academician. Revelaţia a fost "Regele moare", şi bătrânul cronicar se revela sensibil, aproape complice cu angoasa profundă ce a traversat totuşi tot teatrul lui lonesco, oroarea de bătrâneţe, spaima de moarte. 


\section{How „The Bald Soprano” combed her hair, in the past and nowadays}

Mirella Patureau analyses the "The Bald Soprano" by Eugene lonesco directed by Jean-Luc Lagarce, a Vroduction that could be seen this year as invited guest show in Romanian National Theatre Festival. JeanLuc Lagarce is known as playwright by Romanian audience thanks to a successful staging directed by Radu Afrim, "It's only the end of the world". But Mirella Patureau speaks now about the chance to see the last directed directed by Jean Luc Lagarce. The performance is a very special one because "fifteen years after the creation of the text and almost ten years after its director's death, the same actors decide to remake the show keeping it exactly how it was, due to actors' memory and in exactly the same set-design." After talking about the qualities of this production, the critic concludes: the ones who are gone still survives when we keep them in our minds, and so does Jean Luc Lagarce thanks to this show.

fost reconstituirea pas cu pas, a memoriei gestului, a desenului scenic. De fapt, ce conta în primul rând era viziunea regizorului ce răsturna la rândul său în 1991 convenţiile şi propunea o lectură ce spăla pur şi simplu de pe retina spectatorului amintirea de acum "clasică" de la Huchette sau ideea pe care spectatorul contemporan şi-o face despre teatrul absurdului. Ce mi se pare revelator, mai ales pentru epoca noastră, este faptul că odinioară se vorbea despre lonesco ca despre un Picasso al teatrului. Comparaţia vă situează epoca şi omul. În 1991, Lagarce priveşte mai degrabă spre televiziunea anilor '50, mai precis foiletoanele americane cu estetica lor kitsch şi morala tipic mic burgheză. Căci pentru regizor, piesa şi personajele sale trebuiesc jucate serios, au premier degré, căutând chiar, dar amuzându-se de astă dată, un filon poliţist ce sare în ochi, de pildă, dacă luăm d la lettre replica finală a bonei , „de fapt, numele meu este Sherlock Holmes". Cum arată spectacolul? Interiorul burghez cu mobilele sale prăfuite au dispărut. Cât despre indispensabila pendulă ce bate aiurea orele, dar care punctează totuşi trecerea de la o secvenţă la alta, Lagarce a înlocuit-o cu o lună ce străbate cerul la fel de capricioasă şi de neaşteptată. Lagarce decupează astfel scenele prin cortine de lumina dându-le o fluiditate aproape cinematografică, sau mai degrabă de foileton de televiziune, unde nu lipsesc nici hohotele de râs, ce izbucnesc stupide ca în emisiunile de varietăţi. Suntem în exterior, pe o peluză cu un gazon verde impecabil, cu o casă desenată parcă pentru păpuşi, căci dimensiunile sale faţă de actori ne catapultează dincolo de oglindă, acolo unde Alice ia ceaiul cu ducesele şi reginele din jocul de cărţi. Sincer să spun, mă aşteptam să-I văd alergând grăbit pe iepuraşul de martie şi consultându-şi ceasul. Dar nu, personajele rămân ionesciene, ţipător îmbrăcate şi uşor marionetizate. Prost asortate ca talie,un Domn Smith mic şi rotofei, cu o nevastă lungă şi zăludă, căreia îi corespunde o Doamnă Martin, îmbrăcată identic dar mică şi rotofeie. Din fericire, personajele sunt interşanjabile, piesa ar trebui să reînceapă în final, ca în clasicul de acum spectacol al lui Nicolas Batataille de la Huchette, dar Lagarce preferă să-i acorde Bonei privilegiul de a încheia spectacolul şi să spună pur şi simplu didascaliile astfel cum au fost conservate în ediţia publicată a piesei : „Toţi urlă în culmea furiei, luminile se sting, în întuneric se aude pe un ritm din ce în ce mai rapid, nu e pe acolo, e pe aici, nu e pe acolo, e pe aici. Cuvintele se opresc brusc.

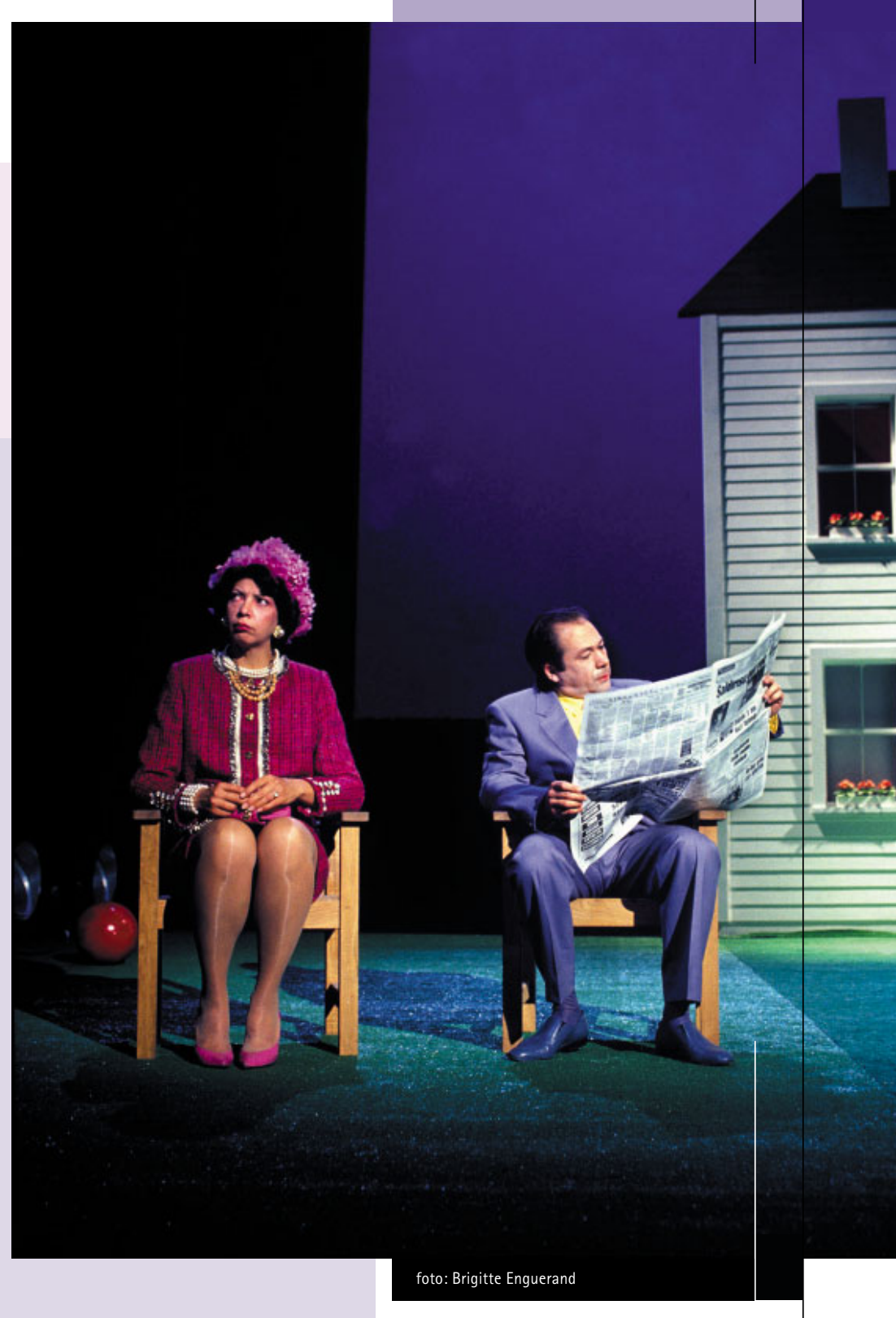

Din nou lumină..." La câteva decenii de la premieră, Nicolas Bataille ${ }^{3}$ care a jucat multă vreme cu aceiaşi interpreţi, avea obiceiul să spună că ceea ce se uza erau numai costumele. Interpreţii lui Lagarce au recroit aceleaşi costume, tocmai bune la talia lor, şi-au regăsit gesturile şi motivaţiile, şi după cincisprezece ani actorii au regăsit plăcerea jocului şi poate undeva, din înălţimile scenei, zâmbetul amuzat al camaradului de odinioară. Se spune că cei dispăruţi trăiesc atâta vreme cât ne mai amintim de ei. „Cântăreaţa cheală" purtată de memoria unui grup de prieteni şi complici fideli o confirmă. 


\section{Film}

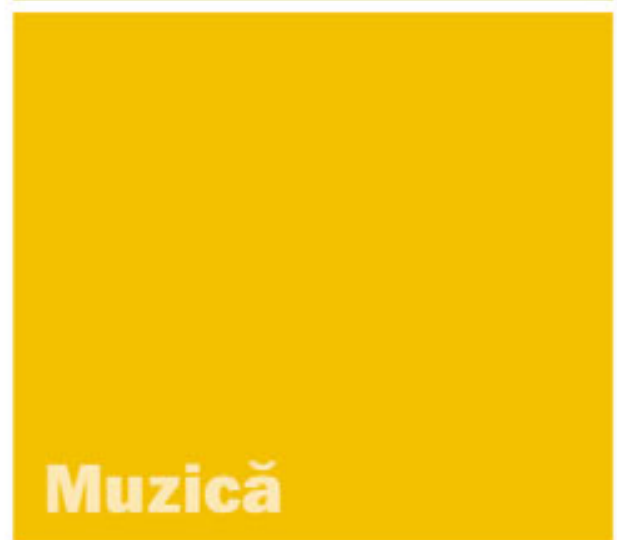

Lifestyle
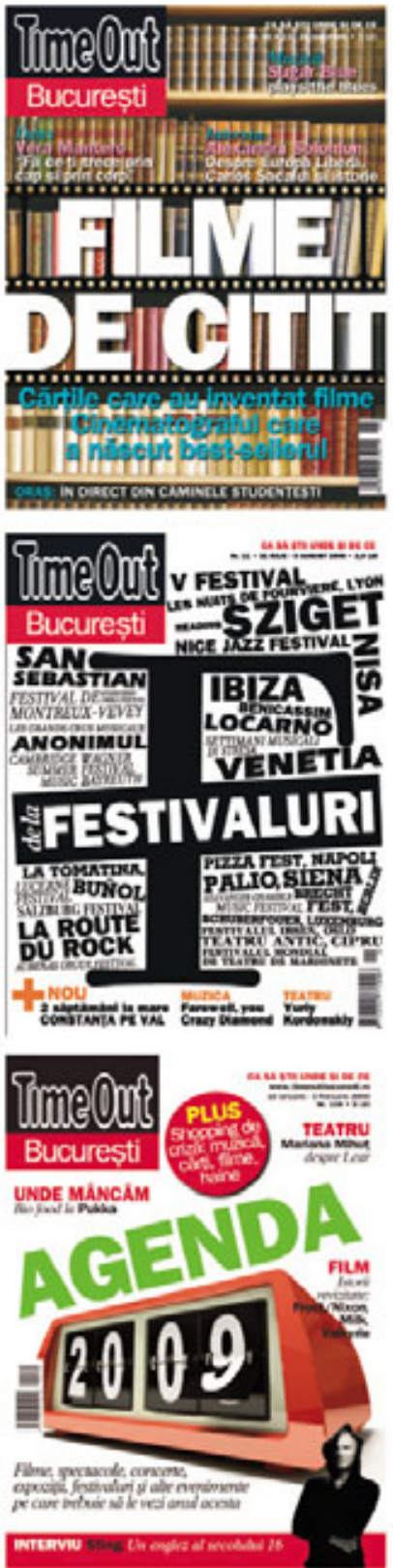
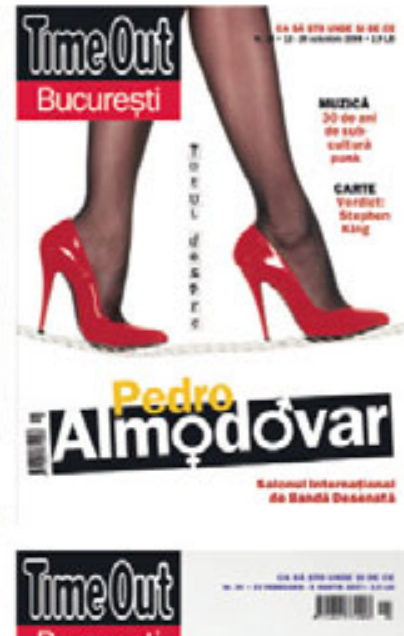
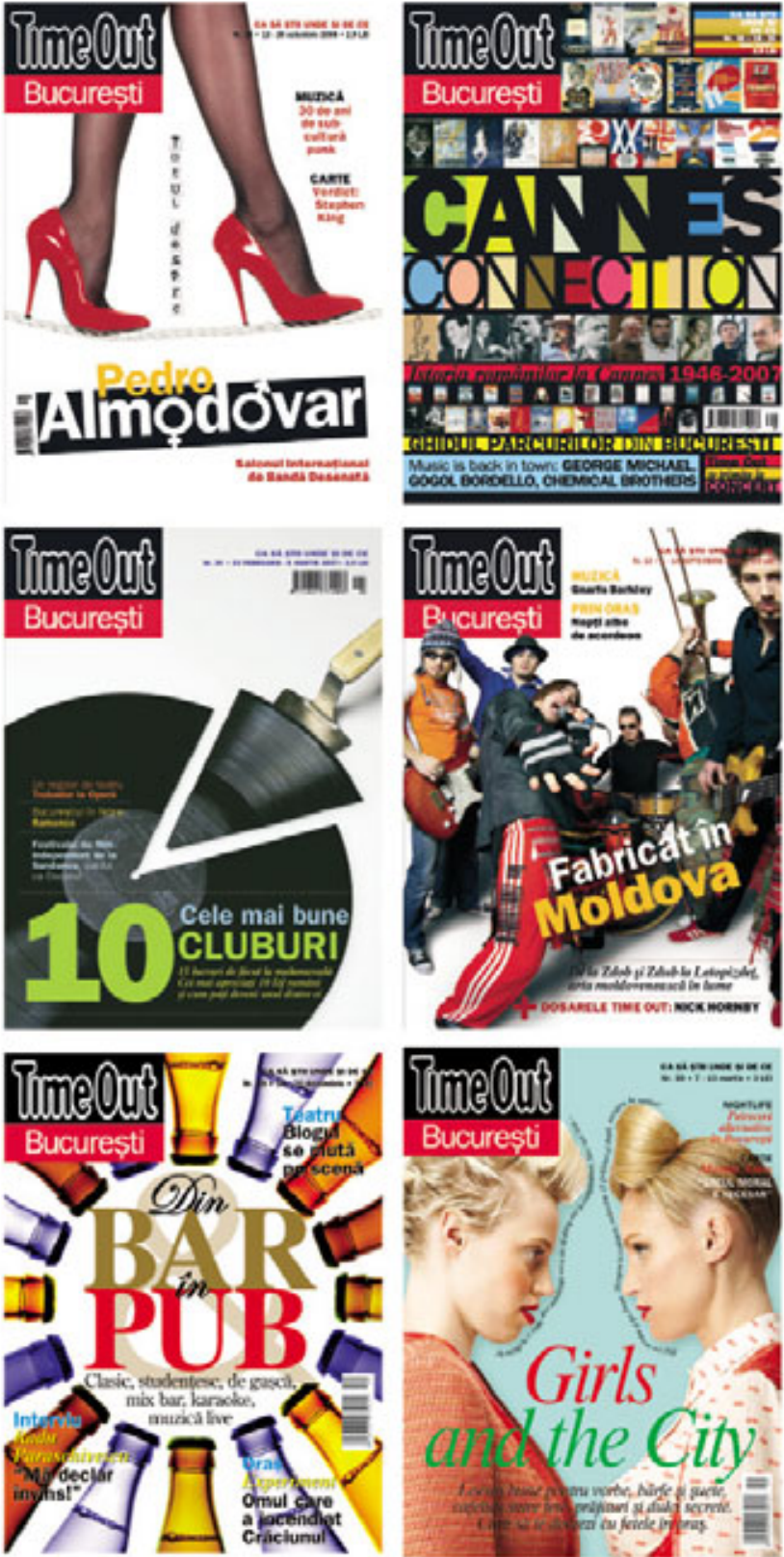

Film. Muzică. Teatru. Dans. Artă. Carte. Nightlife. Restaurante. Evenimente

\section{TIME OUT \\ CASAŞTII \\ UNDEŞI DECE}

timeoutbucuresti.ro

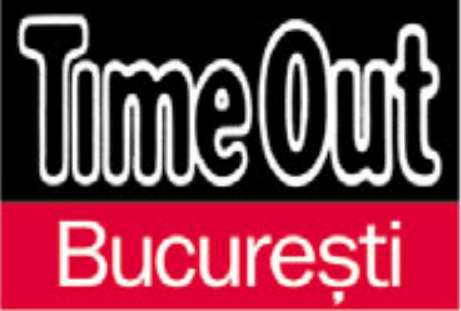




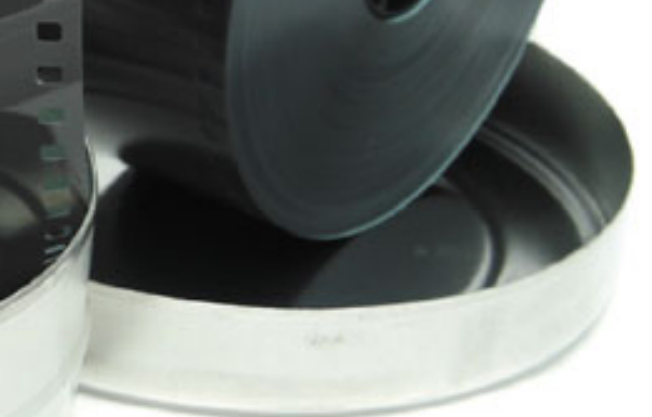

\section{Cans full of images for „living theatre” addicts}

Cristina Modreanu makes a sensitive presentation of each one of Cthe movies included in this year special section of RNTF: Films, Night, Theatre. The audience of the festival has now the chance to see performances or documentaries about famous directors and choreographers that influenced contemporary theatre (Jerzy Grotowski, Pina Bausch, Ariane Mnouchkine, Krystian Lupa, Jaques Leqoq, Richard Schechner and Yoshi Oida). "It's not every day that a documentary succeeds in reaching the essence of its story, but when the subjects are those personalities whose images has became somehow enigmatic in time, it is essential to gather as much information as possible to make the portrait clear." în premieră în limba română, cu proiecţia de filme despre respectivele personalităţi, ceea ce pare, nu numai la prima vedere, o idee extrem de bună de a atrage atenţia "la pătrat" asupra numelor respective. lar când numele respective au intersectat până acum numai întâmplător şi superficial cultura noastră, deși e vorba despre Ariane Mnouchkine, Jaques Leqoq şi Yoshi Oida, unul dintre actorii preferaţi ai lui Peter Brook, nu rămâne decât să încerci să aduci iniţiativa la urechile cât mai multor consumatori de teatru. lar consumul se poate atunci diversifica, teatrul găsindu-se şi sub formă tipărită, şi sub formă de "conservă de imagini". Toate te fac să visezi sau să-ţi aminteşti de contactul cu „teatrul viu", singurul care creează dependenţă.

În momentul în care scriu aici încercând să respect deadline-ul pentru o altă formă de „aperitiv teatral", adică Scena.ro, n-am văzut încă filmele despre Pina Bausch, dar ştiu că unul dintre ele se numeşte „La o cafea cu Pina", iar titlul parcă spune ceva despre relaxare, despre normalitate, despre dans, teatru, sau teatru-dans ca fel de viaţă, despre creaţ̧ie ca preocupare continuă, firească, pasionantă. Filmele despre Pina Bausch sunt primele din seria proiecţiilor nocturne din FNT. Fie ca ele să deschidă apetitul pentru acest surogat de teatru servit în doze potrivite pe timp de noapte. Nimic ilegal aici, dar totul pasionant în mod garantat!

\section{PROMO}

\section{noi mergem dincolo de aparențe}
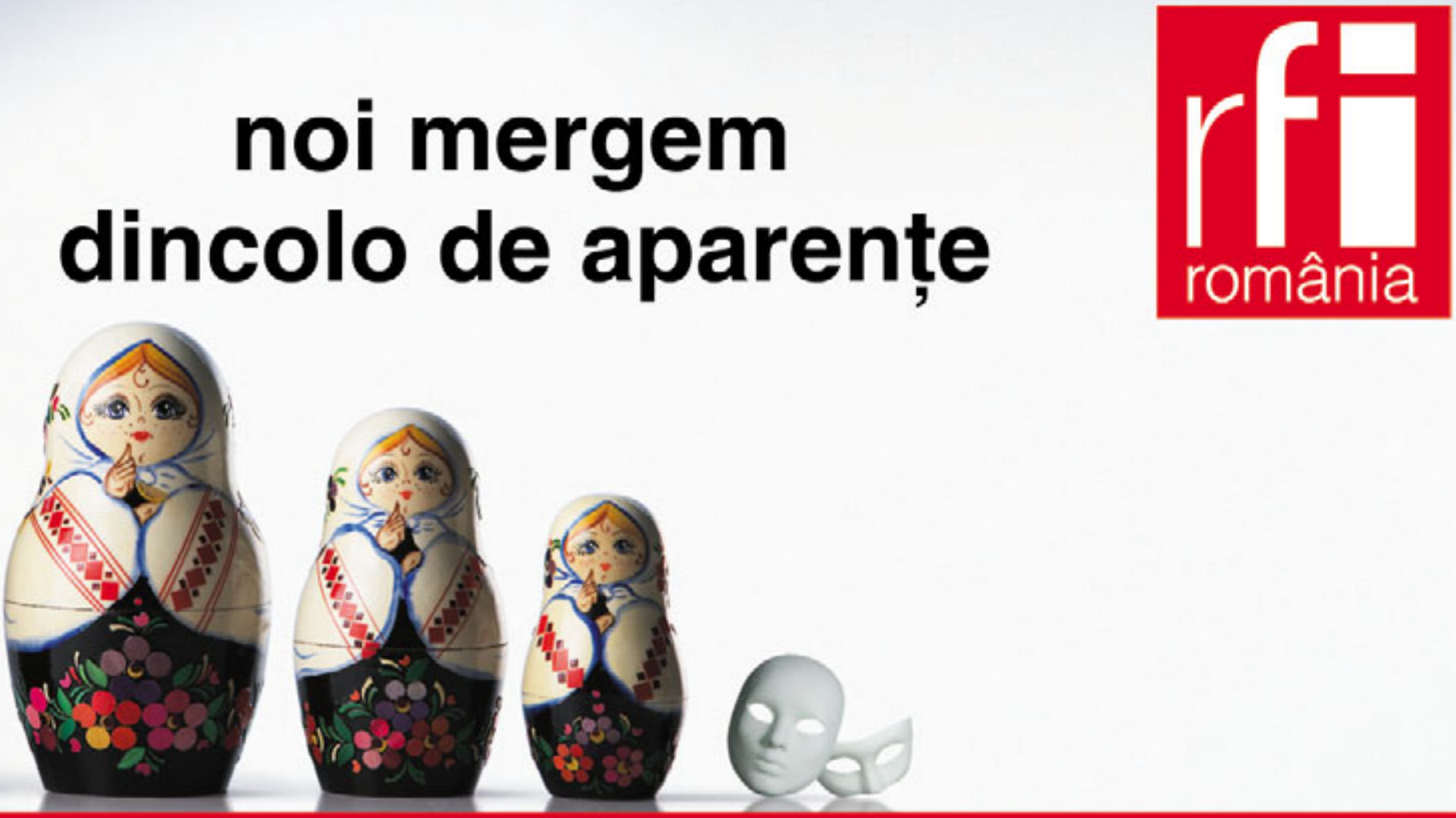

\section{înţelege şi decriptează}

Bucureşti 93.5 fm, laşi 97.9 fm, Craiova 94 fm, Cluj 91.7 fm 

de o tânără ideală, înţelegătoare, care-şi câştigă singură existenţa, Dany-Daisy, combinând graţia cu frumusețea şi un anume savoir-faire. Chiar dacă sunt izolate şi însingurate, într-un sens metafizic, personajele lui lonesco nu sunt în nici un caz vagabonzii lui Beckett sau Adamov, iar acest lucru contribuie într-un anume fel la disperarea şi absurditatea lor, căci ele sunt singure în ciuda apartenenţei la ceea ce ar trebui să fie o comunitate organică. Dar, după cum vedem în "Jacques", familia este agentul de presiune al societăţii întru conformitate, şi nici măcar iubitoarea şi dulcea Daisy din „Rinocerii" nu-i rezistă.

Totuşi, prezenţa prietenilor şi a relaţiilor de familie luminează oarecum disperarea lumii ionesciene. Ar fi o greşeală să considerăm atitudinea lui ca în întregime pesimistă. lonesco vrea să dea valoare şi autenticitate existenţei, prin confruntarea omului cu realitatea crudă a condiției sale. Dar acesta este şi un mod de eliberare. „A ataca

\section{Eugène lonesco. Theatre and antitheatre}

Some excerpts from Martin Esslin's book $S_{\text {"The theatre of the absurd" are selected }}$ by the playwright Alina Nelega, as a foreword to the launch of this book, translated by her into Romanian, and published in RNTF Collection 2009. One can remember that: lonesco wanted to create "a pure theatre, a theatrical theatre"; „It's simply amazing how lonesco innovated in terms of tools needed to reach this purpose". Alain Bosquet isolated not less than thirty six "humor recipes" only in "The Bald Soprano", "the first and, in many aspects, the simpler of his works". Ionesco attacks a world that lost its metaphysical dimension, a world where one cannot feel any mystery no more"; but in his texts one can still detect "a pleading for returning to a poetical concept of life."

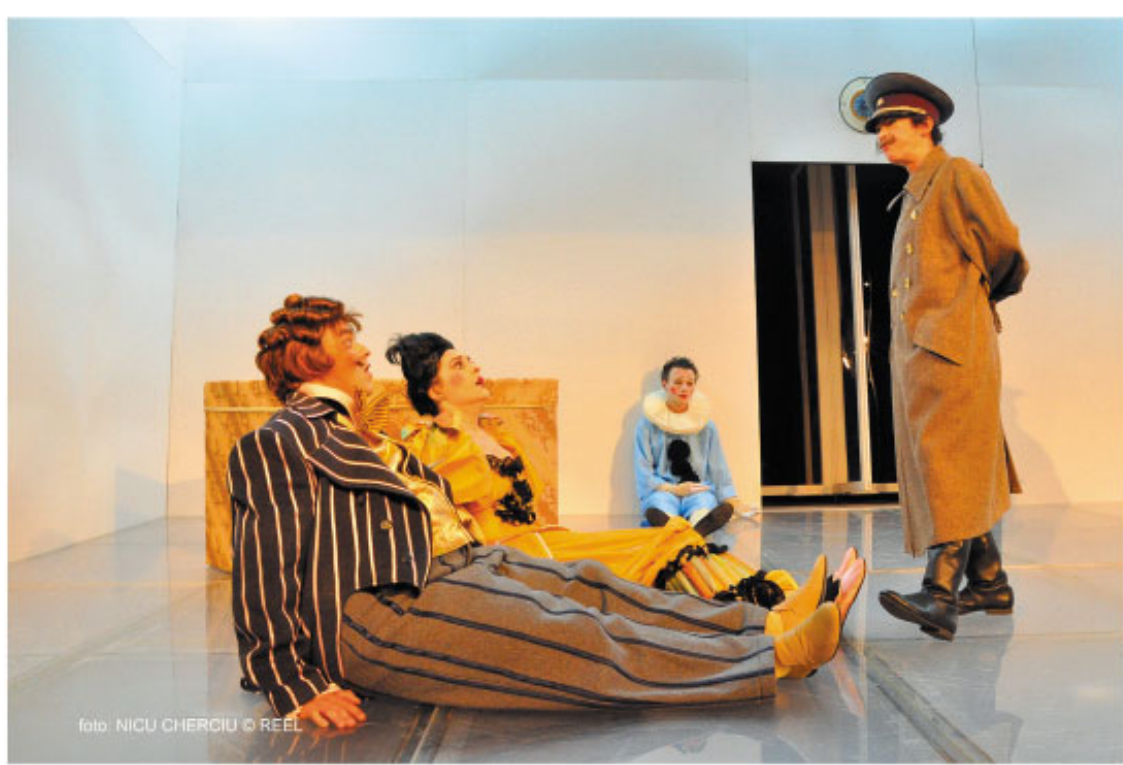

Cântăreaţa cheală // Regia: Tompa Gábor cu o stare de euforie. Dimpotrivă, intuiţia fiinţării pe care el încearcă s-o comunice este una a disperării. Principalele teme care apar în piesele lui sunt cele ale însingurării şi izolării individului, a dificultăţii de comunicare cu ceilalţi, cedarea în faţa presiunilor exterioare, a conformismului mecanic al societăţii, ca şi lipsa de rezistenţă, la fel de degradantă, la presiunile interioare ale propriei personalităţi: sexualitatea şi sentimentul ulterior de vină, neliniştea care vine din lipsa de certitudine asupra identităţii proprii, dar şi din certitudinea morţii.

Dacă structura pieselor lui Beckett se bazează pe cupluri de personalităţ̧i interdependente, complementare, în teatrul lui Adamov pe personaje contrastante, extrovert-introverte, la lonesco cel mai adesea se regăseşte cuplul căsătorit, familia: dl. şi d-na Smith, Amedeu şi Madeleine, Choubert şi Madeleine a lui, cei doi bătrâni din "Scaunele", familia Jacques din „Jacques” şi „Viitorul e în ouă”, profesorul şi fata lui în casă (care îi este soţie şi mamă în acelaşi timp) din „Lecţia", Domnul cel gras şi Alice, sora lui, în „Tabloul". În această structură de bază, femeia joacă de obicei rolul unui suporter care-şi admiră, dar îşi şi cicăleşte bărbatul. În piesele de mai târziu, Bérenger e un tip singuratic şi izolat, însă de fiecare dată îndrăgostit

\footnotetext{
${ }^{3}$ Ionesco, citat de Towarnicki în "Des Chaises vides à Broadway"
}

absurditatea (condiţiei umane) este un mod de a declara posibilitatea non-absurdului...căci altfel unde am găsi un punct de referinţă?... În budismul Zen nu există învăţare directă, doar cercetarea constantă spre o deschidere, o revelaţie. Nimic nu mă face mai pesimist decât obligaţia de a nu fi pesimist. Simt că fiecare mesaj de disperare este 0 atestare a unei situaţii din care fiecare trebuie să-şi găsească singur scăparea"3

Această atestare a situaţiei disperate, capacitatea pe care i-o conferă spectatorului de a o înfrunta cu ochii deschişi, constituie ea însăşi un catharsis, o eliberare. Oare Oedip şi Lear nu se confruntă şi ei cu disperarea şi absurditatea condiţiei lor umane? Şi totuşi, tragediile lor sunt experienţe eliberatoare. Ionesco însuşi s-a opus în permanenţă ideii că el, ca autor avangardist, se situează în afara curentului principal al tradiţiei. A susţinut mereu că avangarda e doar o redescoperire a unor zone pierdute ale tradiţiei. Şi astfel, chiar dacă recunoaşte că îl găseşte pe Corneille plicticos, pe Schiller de nesuportat, pe Marivaux futil, pe Musset subţire, pe Vigny de nejucat, pe Hugo ridicol, pe Labiche necomic, pe Dumas-fiul ridicol de patetic, pe Oscar Wilde facil, pe Ibsen greoi, pe Strindberg lipsit de meşteşug, pe Pirandello demodat, pe Giraudox şi Cocteau superficiali, se vede pe sine ca parte a tradiţiei, alături de Sofocle şi Eschil, Shakespeare, Kleist şi Büchner, tocmai fiindcă acești autori sunt preocupaţi de condiţia umană în toată absurditatea ei brutală.

"Fragment din "Teatrul absurdului" de Martin Esslin, versiune în limba română de Alina Nelega, (Bucureşti:Unitext şi FNT, 2009), pp. 175-179 


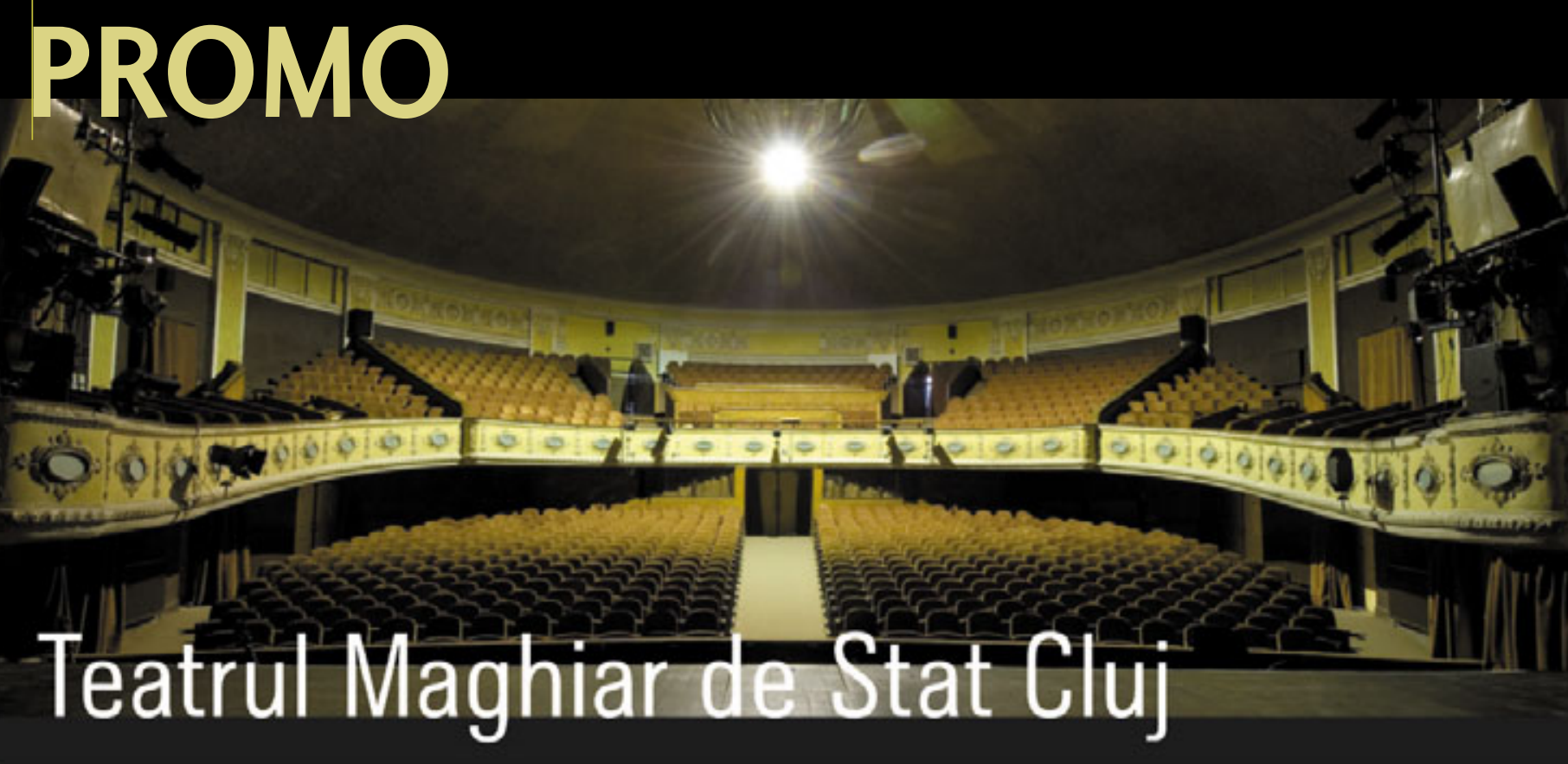

\section{Microstagiune în perioada 12 - 16 decembrie 2009}

Sâmbătă, 12 decembrie ora 19.00

\section{A. P Cehov}

\section{Unchiul Vania}

regia: Andrei Serban

premiul UNITER pentru Cel mai bun spectacol al anului 2007, pentru Cea mai bună regie (Andrei Serban) si pentru Cel mai bun actor in rol principal (András Hatházi) si premiul

criticilor de teatru din Ungaria pentru Cel mai bun spectacol al stagiunii $2007 / 2008$.

Duminică, 13 decembrie ora 19.00

William Shakespeare

\section{Richard III}

regia: Gábor Tompa

Luni, 14 decembrie ora 20.00

Georg Büchner

\section{Moartea lui Danton}

regia: Mihai Măniuțiu

Marți, 15 decembrie ora 20.00

András Visky

Născut pentru niciodată

regia: Gábor Tompa

Pascal Bély: „Cel mal bun spectacol din programul off al Festivalului din Avignon, ediția 2009."

Miercuri, 16 decembrie ora 19.00

A. P. Cehov

\section{Trei surori}

\section{regia: Gábor Tompa}

premiul UNITER pentru Cel mai bun spectacol al anului 2008 sí pentru Cea mai bună regie (Gábor Tompa).

Spectacolele vor fi traduse în limba română.
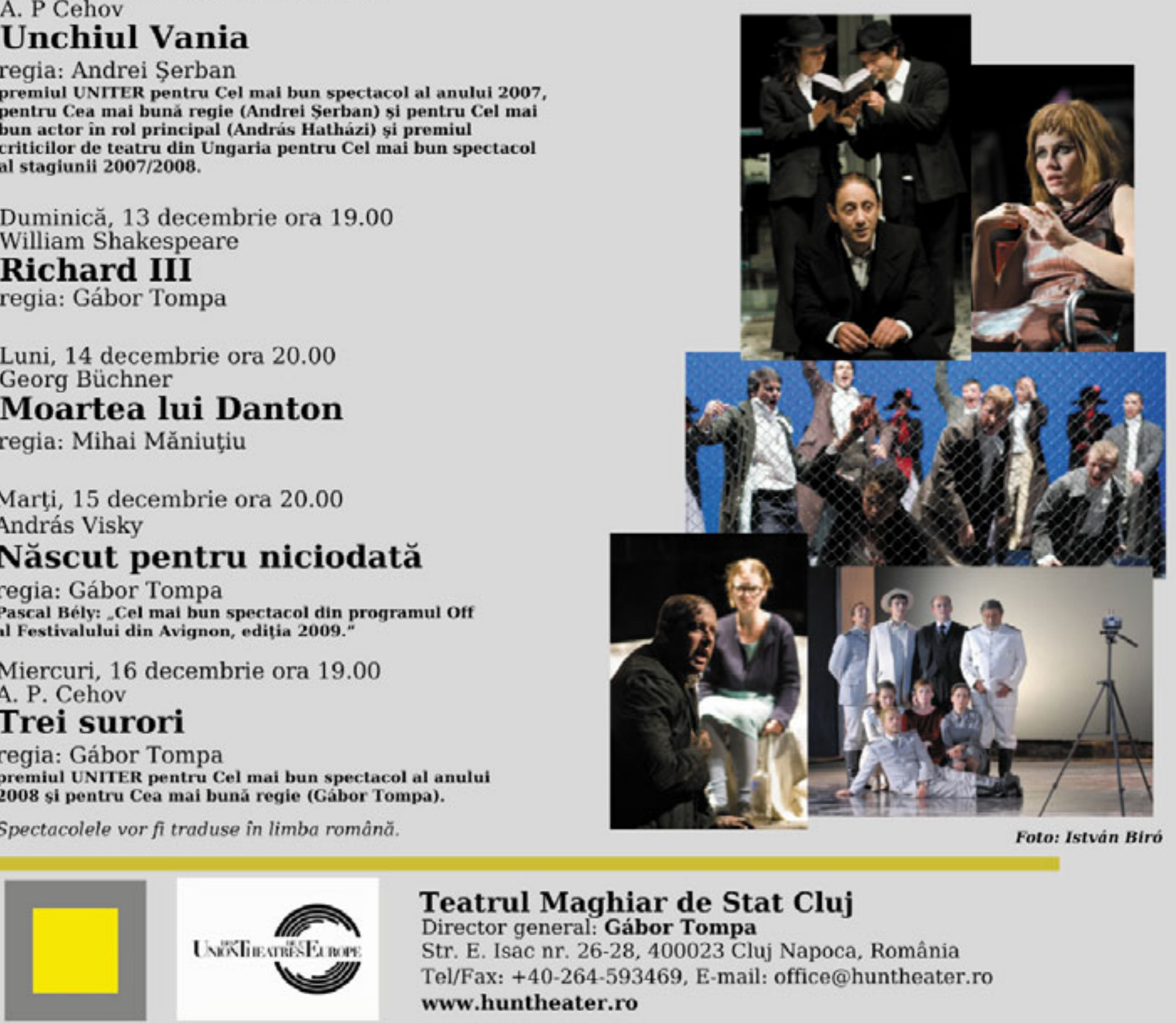

Teatrul Maghiar de Stat Cluj

Director general: Gábor Tompa

Str. E. Isac nr. 26-28, 400023 Cluj Napoca, România

Tel/Fax: +40-264-593469, E-mail: office@huntheater.ro

www.huntheater.ro 

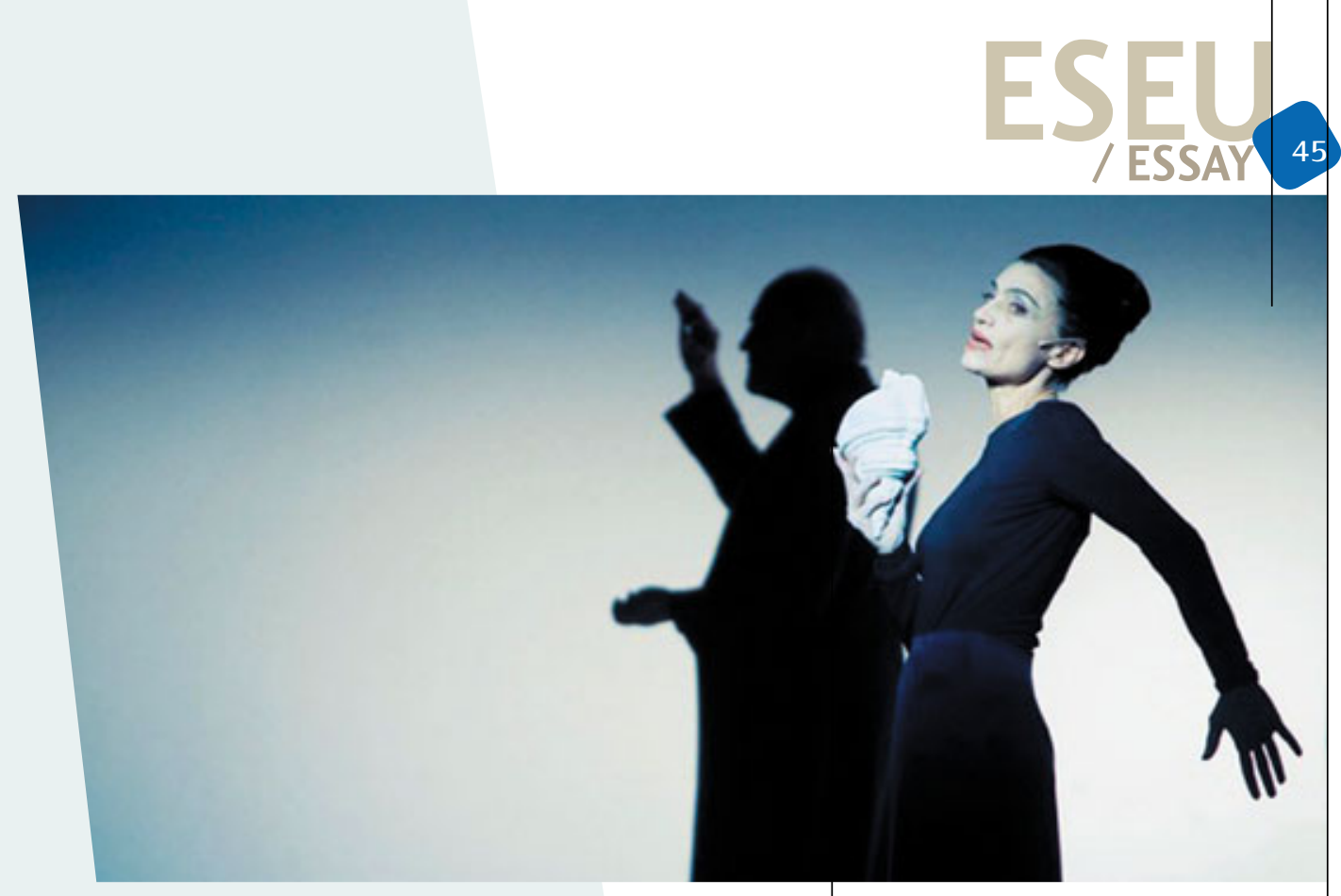

cărei faţă arde, cei trei înţelepţi de la Răsărit, un foc apocaliptic şi un dinozaur: istorie şi preistorie, nu în sensul unei înţelegeri istoricodialectice, ci ca horă de imagini. Sunt numeroase imaginile lui Wilson care, direct sau indirect, invocă mituri vechi într-o copleşitoare abundenţă de motive şi personaje istorice, religioase şi literare mai noi. Pentru Wilson, se cuvine ca ele să se regăsească laolaltă în cosmosul imaginativ şi, într-un sens mai larg, ele sunt, toate, mitice: Freud, Einstein, Edison şi Stalin; Regina Victoria şi Lohengrin; Parcival, Salomeea, Faust şi fraţii din epopeea lui Ghilgameş, Parcival în versiunea lui Tankred Dorst la Hamburg, Sfântul Sebastian la Bobigny, Regele Lear la Frankfurt pe Main. 0 listă incompletă de elemente mitice, cvasimitice şi pseudomitice din teatrul său sugerează totodată apetitul jucăuş de a cita din rezervorul de imagini al omenirii, care refuză să lase vreo logică centripetă să-i traseze graniţe. Îşi fac apariţia: arca lui Noe, Cartea lui lona, Leviatanul, texte indiene vechi şi noi, o corabie vikingă, obiecte africane de cult, Atlantida, balena albă, Stonehenge, Micene, piramidele, bărbatul egiptean cu mască de crocodil, făpturi misterioase inventate de el precum Mama Pământului, Femeia-Pasăre şi Pasărea albă a morţii, Sfânta loana, Don Quijote, Tarzan, căpitanul Nemo, Craiul lelelor al lui Goethe, indieni Hopi, Florence Nightingale, Mata Hari, madame Curie... Lista ar putea fi continuată.

Teatrul lui Wilson e neomitic, dar cu miturile doar pe post de imagini care poartă în ele acţiunea numai ca fantezie virtuală. Ca povestiri cu o profundă semnificaţie alegorică, Prometeu şi Hercule, Fedra şi Medeea, Sfinxul şi dragonii trăiesc, prin secole, ca obiecte de uz casnic ale imaginaţiei artistice. În acelaşi timp, însă, ele există ca simple imagini cu care sunt familiarizaţi până şi aceia care nu au "cultură". Fie că ştie, fie că nu, tot omul "cunoaşte" personaje acţionând inconştient în discursul cultural, Hercule şi monştrii, pe Medeea cu copiii ei, pe răsculatul Prometeu, pe fraţii învrăjbiţi Polinice şi Eteocle. Nu altfel stau lucrurile cu personaje din epoci mai noi precum Don Juan, Faust sau Parcival. Într-o epocă în care naraţiunea structurată "normal" abia dacă mai atinge densitatea miticului, teatrul lui Wilson încearcă să se apropie de logica preraţională a lumilor imagistice ale miturilor. Dacă totuşi cineva ezită să recunoască vreo legătură „la modul serios" între arta circului, aşa cum caracterizează ea teatrul lui Wilson, şi mit, obiecţia este îndreptăţită: imageriile mitice apar aici în locul acţiunii, ca apetit "postmodern" de a cita universuri plastice a căror vreme a trecut. Pe de altă parte, o privire asupra istoriei teatrului ne arată că nici în epocile mai timpurii mitul şi entertainmentul nu erau neapărat antagonice. Wilson se înscrie într-o lungă tradiţie a teatrului de efecte baroc, al maşinăriilor secolului XVII, a măştilor iacobine, al teatrului victorian obsedat de spectaculos, până la show şi jocurile din circul epocii moderne, care au încorporat dintotdeauna în repertoriul lor profunzimea şi atracţia clişeelor mitice.

Deoarece, la Wilson, fenomenul se bucură de prioritate faţă de naraţiune, efectul imaginilor e mai important decât actorul individual, teatrul lui creează un timp al privirii. Teatrul acesta este lipsit de sentiment tragic sau de compasiune, el dă dovadă de tristeţe. În plus, pictura de lumini a lui Wilson întăreşte unitatea dintre procesul natural şi întâmplările omeneşti. Şi aceasta este una dintre cauzele pentru care tot ceea ce actorii fac, spun şi manifestă prin mişcările lor îşi pierde caracterul de acţiune intenţionată. Acţiunile lor par să se desfăşoare ca în vis şi „astfel pierd al acţiunii nume", cum spune Hamlet. Ei se preschimbă în întâmplare. Oamenii devin sculpturi gestuale. Asocierea cu pictura tridimensională face ca lucrurile să ne apară ca nature morte, actorii ca nişte mişcătoare portrete la scara unu pe unu. Wilson trasează explicit comparaţia între teatrul său şi procesele naturale. De aceea, noţiunea de peisaj preia aici şi semnificaţia care-i este asociată într-o formulare a lui Heiner
Müller, aceea referitoare la „peisajul care aşteaptă dispariţia treptată a omului": intrarea acţiunilor omeneşti într-un context ţinând de istoria naturală. La fel ca în mit, viaţa apare ca moment al cosmosului. Omul nu este despărţit de peisaj, animal şi piatră. 0 stâncă se poate prăbuşi cu încetinitorul, animalele şi plantele sunt în egală măsură agenţi ai lucrurilor care se întâmplă, ca şi fiinţele omeneşti. Atunci când conceptul de acţiune se dizolvă în asemenea măsură în favoarea unei derulări de metamorfoze continue, spaţiul acţiunii apare asemenea unui peisaj transformat în permanenţă de diferite stări de lumină, de obiecte şi de personaje care apar şi dispar.

Fragment din "Teatrul postdramatic" de Hans Thies Lehmann, traducerea Victor Scoradeț. Volumul a apărut în premieră în limba română în Colecția FNT, editată în colaborare cu Editura Unitext 


\section{ESEU}

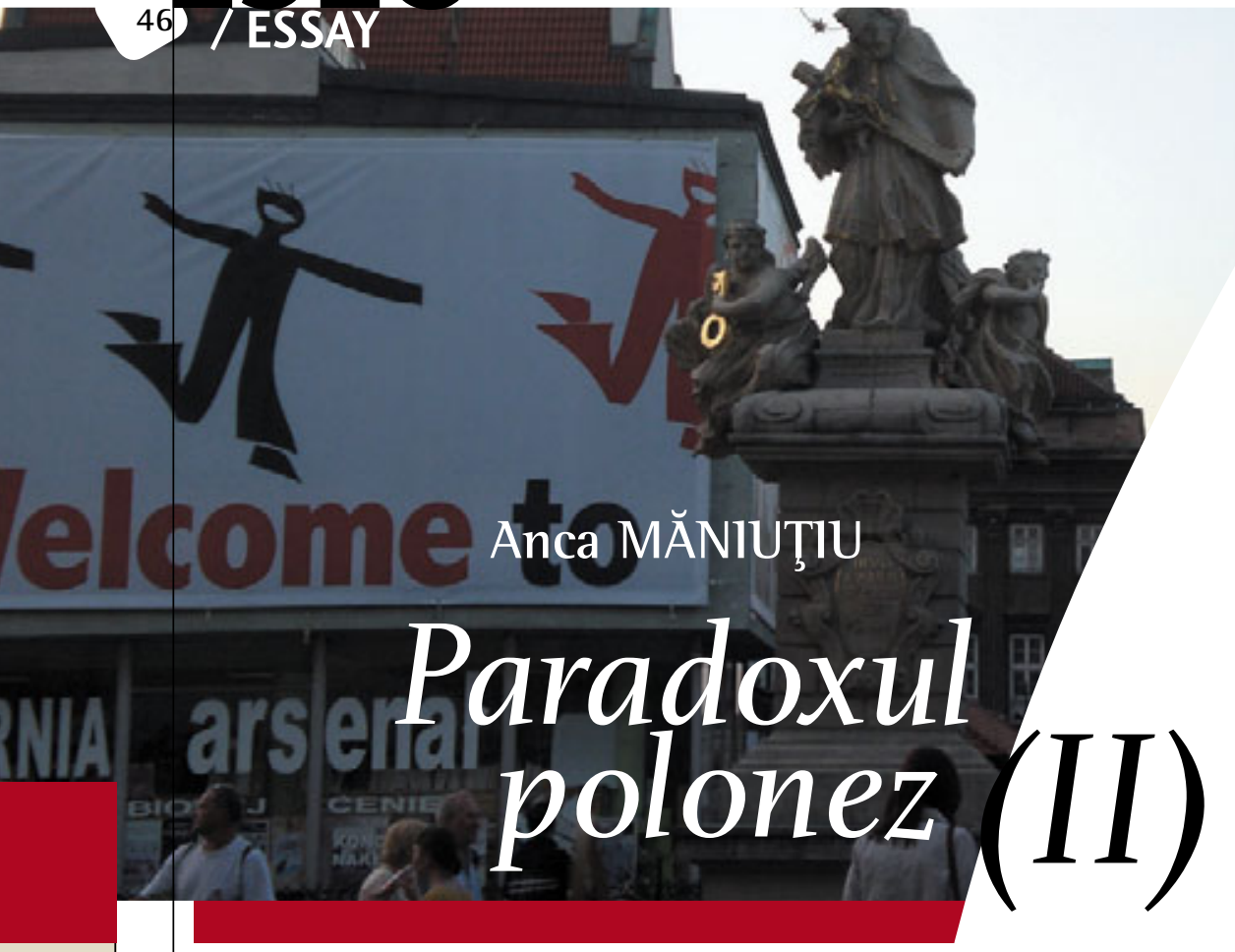

\section{The Polish Paradox (11)}

In the second part of her essay on Polish theatrical culture Anca Măniuţiu observes that Polish people have an immense respect for this art. They bury their playwrights in cathedrals and build statues for the most famous directors. More than that, almost all major social events meant to change the way people were living in the communist regime were related or even generated by theater people. After giving a couple of examples of such events, Anca Măniuţiu ends her intervention with a comparison between Polish theater and Romanian theater, and concludes the last was never so present in Romanian society of the time.
În contextul legăturii indisolubile dintre istoria lor zbuciumată şi cultura văzută ca un mijloc de rezistenţă în faţa opresiunii şi de salvgardare a fiinţei naţionale, nu trebuie să ne mire faptul că polonezii îşi înmormântează marii dramaturgi şi scriitori în catedrale (Adam Mickiewicz şi Juliusz Slowacki în catedrala Wawel din Cracovia, Stanislaw Wyspianski în biserica Skalka din Cracovia) sau că ridică statui regizorilor - vezi statuia dezvelită la Lodz, în 1982, de Ziua Mondială a Teatrului, în memoria lui Leon Schiller ${ }^{1}$.

De altfel, multe dintre evenimentele dramatice din perioada comunistă au un simbol teatral ori sunt la originea unor miş̧ări protestatare. Astfel, de pildă, scânteia care a declanşat marile mişcări studenţeşti de protest din martie 1968 (devansându-le pe cele ce vor izbucni în Europa occidentală) a fost manifestaţia studenţilor din 30 ianuarie, în faţa monumentului lui Adam Mickiewicz din Varşovia, împotriva interzicerii spectacolului cu piesa "Strămoşii" („Dziady"), pus în scenă de Kazimierz Dejmek la Teatr Narodowy (Teatrul Naţional). Premiera avusese loc în noiembrie 1967 şi, după mai multe reprezentaţii, autorităţile au anunţat că vor retrage de pe afiş spectacolul, „în urma atitudinii necorespunzătoare a publicului" (adică a entuziasmului său excesiv). "Strămoşii" lui Mickiewicz, considerat de autorităţile comuniste „o provocare politică", era un protest împotriva aservirii Poloniei, după partajul ei de către cele trei puteri străine, în 1795. Ultima reprezentaţie (cea de-a unsprezecea) a fost anunţată pentru 30 ianuarie 1968, iar publicul era format în majoritate din studenţi. Spectacolul a fost întrerupt, în repetate rânduri, de aplauze puternice, iar la sfârşit s-au scandat sloganurile "Independenţă fără cenzură!", „Vrem cultură fără cenzură!". La ieşirea din teatru, un grup de studenţi s-a îndreptat spre monumentul lui Mickiewicz, în jurul lui adunându-se o mulţime de oameni. Miliţia a intervenit rapid şi cu violenţă, arestând 35 de manifestanţi, dintre care 8 au fost reţinuţi, urmând să li se facă proces. Printre aceştia, Adam Michnik şi Henryk Szlajfer, exmatriculaţi din universitate, cu acest prilej. Reacţiile nu vor întârzia să se arate. Urmează meetinguri de protest ale studenţilor de la universităţile din Varşovia, Wrocław, Łodz, Cracovia, Pozna, Toru et Gdask, protestul Uniunii Scriitorilor Polonezi, care a votat o rezoluţie denunţând politica culturală a regimului comunist, cerând suprimarea cenzurii şi dreptul la libertatea de creaţie. Episcopatul polonez s-a alăturat acestor proteste. La Congresul Partidului din 19 martie, Gomułka a denunţat spectacolul "Strămoşii" ca antisovietic şi mişcarea studenţilor drept antisocialistă, instigată de "duşmanii Republicii populare". Dincolo de arestări, represaliile au inclus închiderea a şase departamente din universitatea varşoviană şi darea afară a numeroşi profesori. Regizorul Kazimierz Dejmek a plecat în 1969 în exil, fiind invitat să monteze la prestigioase teatre europene, printre care Teatrul Naţional din Oslo şi Piccolo Teatro din Milano al lui Strehler. După întoarcerea sa în Polonia, în 1972, Dejmek a continuat să monteze, devenind, în 1974, directorul Teatrului Nowy din Varşovia. Între 1993 şi 1996 a fost ministru al culturii. Moare în 2002, în timp ce lucra la montarea sa cu „Hamlet". În memoria sa, Teatr Nowy îi poartă, începând din 2008, numele.

Cert e că eroul "generaţiei din martie 1968" a fost poetul şi dramaturgul Adam Mickiewicz (la Cracovia şi Varşovia, studenţii se adunau întotdeauna la picioarele monumentului său). După cum ni se spune într-un articol de Tadeusz Nycek, din 1981, intitulat „Poezia generaţ̧iei '68", "Martie polonez a fost şi drama cuvântului, drama adevărului şi a minciunii, a adevărului tradus în minciună. Sloganul cel mai celebru în martie a fost: «Presa minte!!. Tinerii au înţeles exact atunci ce înseamnă manipularea limbii şi, în consecinţă, manipularea conştiinţei umane. Poezia generaţiei $68 \mathrm{~s}$-a născut din această convingere că o mărturie despre adevăr e absolut necesară, despre un adevăr osândit la tăcere şi dispreţ"2. Mai târziu, odată cu reformele iniţiate după august 1980, va fi montat, la Teatr Powszechny din Varşovia, un spectacol intitulat "Toate reprezentaţiile rezervate", articulat în jurul textelor unor poeţi polonezi ai generaţiei 68. Istoria acestei creaţii datează din 1975, an în care Teatr Powszechny îşi propusese să prezinte pe mica sa scenă un spectacol de poeme puse pe muzică şi intitulat „Discoteca poeţilor". Spectacolul nu primise însă acordul autorităţilor, crearea lui devenind posibilă doar după august 1980, când textelor de atunci li s-au adăugat poeme nepublicate, care fuseseră difuzate, în ultimii cinci ani, în samizdat. Acesta este încă un exemplu, printre multe altele descoperite în paginile revistei "Le Théâtre en Pologne / The Theatre in Poland", de recuperare a memoriei, de întoarcere a artei la o dimensiune civică: euforia tranziţiei spre normalitate (sau ceea ce părea atunci, în 1980-1981, să promită recâştigarea unei normalităţi politice, sociale şi economice)

\footnotetext{
${ }^{1}$ Marele regizor Leon Schiller (1887-1954), prieten cu E. Gordon Craig şi colaborator la revista acestuia "The Mask", a fost creatorul aşa-numitului curent de "teatru monumental" polonez, al cărui nume se asociază cu realizările celebrului Teatr Reduta din Varşovia, primul laborator de teatru experimental polonez, fondat de Juliusz Osterwa, în 1919. 2 "Le Théâtre en Pologne/ The Theatre in Poland", nr. 6-7, 1981, p.18.
} 

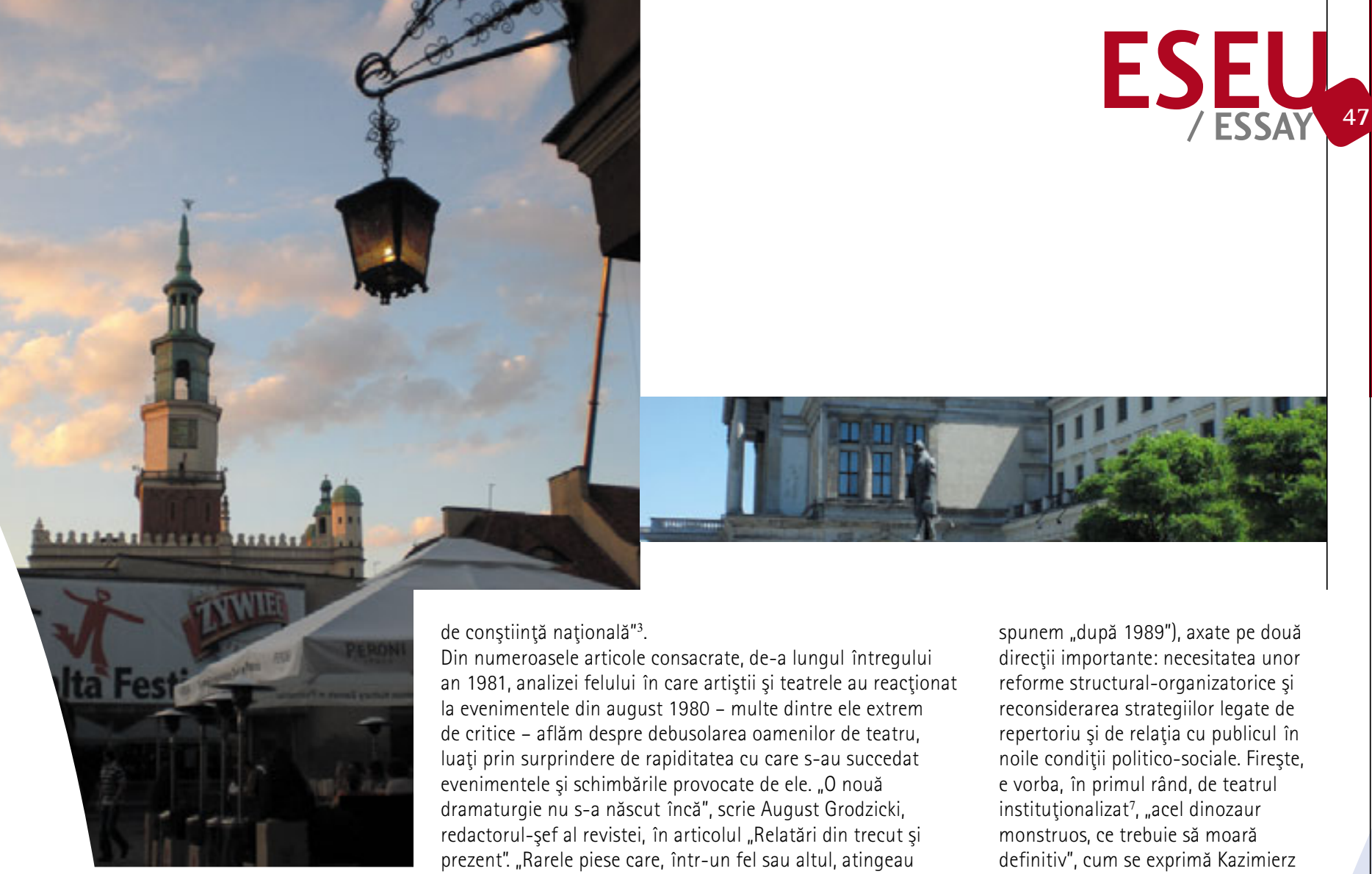

de conştiinţă naţională"3.

Din numeroasele articole consacrate, de-a lungul întregului an 1981, analizei felului în care artiştii şi teatrele au reacţionat la evenimentele din august 1980 - multe dintre ele extrem de critice - aflăm despre debusolarea oamenilor de teatru, luaţi prin surprindere de rapiditatea cu care s-au succedat evenimentele şi schimbările provocate de ele. „0 nouă dramaturgie nu s-a născut încă", scrie August Grodzicki, redactorul-şef al revistei, în articolul "Relatări din trecut şi prezent". „Rarele piese care, într-un fel sau altul, atingeau metaforic problemele vitale pentru societate, au pălit în fața naturii dramatice a evenimentelor şi a reflectării lor de către mijloacele mass media. Teatrului îi trebuie timp să-şi revină şi să-şi regăsească forţa, dar pentru asta e nevoie de schimbări structurale şi ideologice. Până atunci, el apelează la jumătăţi de măsură şi la paleative."4 Termenii nu sunt neapărat pejorativi, dar ei ascund dezamăgirea că teatrele nu au ieşit la rampă cu spectacole revelatorii, cu un conţinut şi o estetică novatoare. Aceste "paleative" sunt cabaretul satiric ${ }^{5}$, la care se întorc multe teatre, formula montajelor poetice, care teatralizează poezia generaţiei 68 , interzisă până atunci de cenzură, şi spectacolele care au o dimensiune documentară şi jurnalistică. Dintre acestea, să amintesc „Acuzat: iunie 56", după un scenariu de Izabella Cywinska şi Wlodzimierz Braniecki, în regia Izabellei Cywinska şi a lui Janusz Michalowski, montat la Teatr Nowy din Poznan, un spectacol sobru, bazat pe documente şi relatări ale martorilor revoltelor de la Poznan, din iunie 1956, precum şi pe înregistrările radiofonice ale proceselor demarate în octombrie 1956, în care actorii nu joacă de fapt, ci povestesc textele transcrise de pe banda magnetică - cuvintele simple, stângace ale celor acuzaţi, amestecându-se cu cele brutale şi cu lozincile acuzatorilor. Începutul spectacolului îl constituie înregistrarea originală a faimosului discurs al prim-ministrului de atunci, Jozef Cyrankiewicz, care se aude la un difuzor şi care conţine ameninţarea, nu mai puţin faimoasă, cu amputarea mâinii care ar cuteza să se ridice împotriva puterií.

Ar mai fi multe de spus despre dezbaterile lucide şi profunde, publicate în revistă, privind "starea teatrului polonez după august 1980" (sintagmă care revine frecvent, aşa cum noi spunem „după 1989"), axate pe două direcţii importante: necesitatea unor reforme structural-organizatorice şi reconsiderarea strategiilor legate de repertoriu şi de relaţia cu publicul în noile condiţii politico-sociale. Fireşte, e vorba, în primul rând, de teatrul instituţionalizat? ${ }^{7}$, acel dinozaur monstruos, ce trebuie să moară definitiv", cum se exprimă Kazimierz Dejmek $^{8}$, acel "birou de funcţionari creat pentru funcţionari (...) care evoluează într-un univers de cifre şi de indici, (...) o ficţiune care poartă numele de abstracţiune birocratică", spune la rândul său criticul Jan Klossowicz, într-un eseu intitulat "Teatrul Arde"9, care ne revelă aspecte deloc idilice, izbitor de asemănătoare cu modul de funcţionare a teatrelor instituţionalizate la noi, în trecut şi în prezent (sic!).

Paradoxul face că, citind revista, te cuprinde o euforie amară, căci, dincolo de senzația benefică pe care ţi-o dă, aceea de a te afla într-un spaţiu larg, respirabil, un spaţiu teatral viu, locuit de oameni posedaţi de obsesia autenticului şi a adevărului, nu poți uita nici o clipă ce le-a rezervat istoria polonezilor, după decretarea legii marţiale, în decembrie 1981. Aşa cum nici o clipă nu poţi uita cenuşiul, exasperarea şi marasmul în care teatrul românesc se cufunda tot mai tare în aceeaşi perioadă.

(va urma)

\footnotetext{
3 Ibidem

4 Ibidem, p. 25.

${ }^{5}$ Ca de pildă spectacolul "Joc de Crăciun pentru prezent", calificat drept "foarte bun", montat de Andrzej Jarecki, directorul Teatrului Rozmaitosc, pe canavaua evenimentelor din august 1980 de la şantierele Lenin din Gdansk si a celor care au urmat.

${ }^{6}$ Vezi T.P., nr. 10-11/ 1981, p. 18.
}

7 În 1981, în Polonia existau 60 teatre dramatice, 20 teatre muzicale şi 26 teatre de marionete. Vezi T.P., nr.8/ 1981, p. 21. Pe lângă acestea, funcţionau zeci de trupe "alternative", cu statut semiprofesionist.
${ }^{8}$ T.P., nr. 10-11/1981, p. 42. lată şi continuarea citatului, care redă succint, printr-o metaforă sugestivă, aşteptările oamenilor de teatru: .... pentru ca pe pajiş tea teatrului să zburde un mânz, plin de viaţă şi de speranţă, cu toate riscurile pe care le implică acțiunea şi viaţa". ${ }_{9}^{9}$ Publicat iniţial în Literatura nr. 12/1981. Vezi T.P., nr 6-7/ 1981, p. 42. 


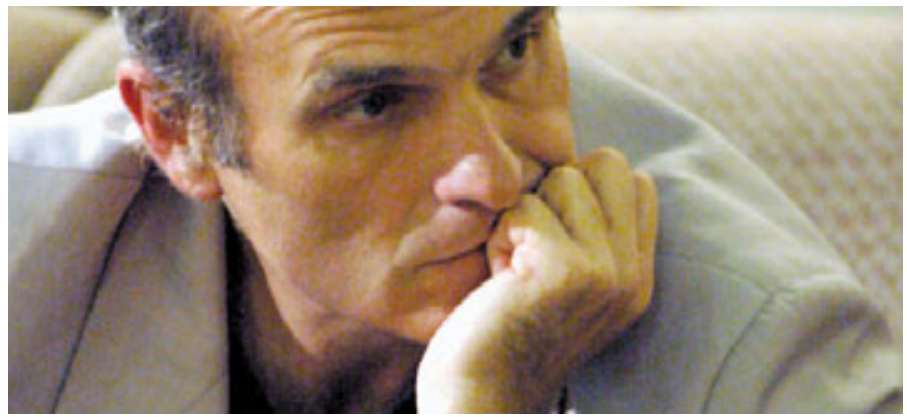

\section{Cristian Tudor POPESCU}

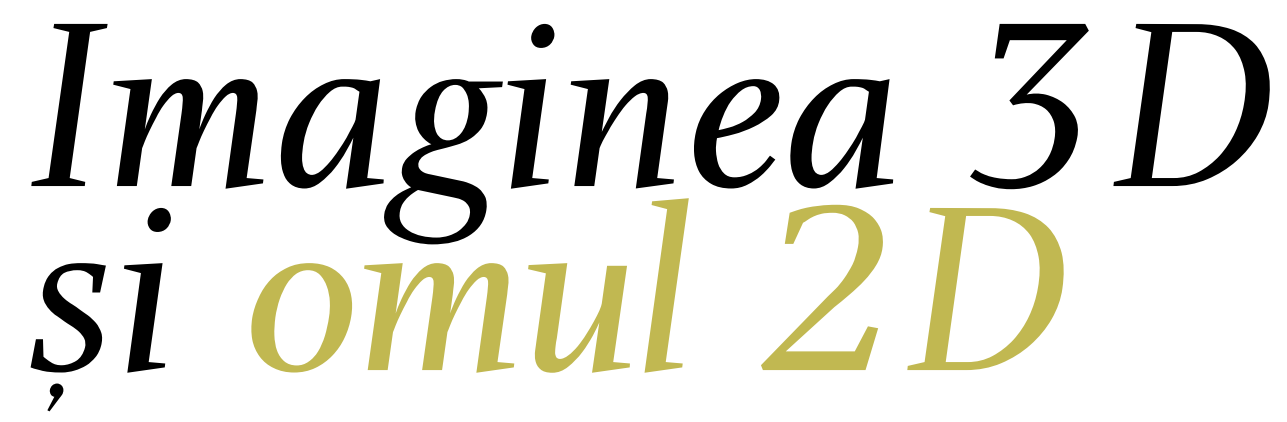

\section{D lmage and 2D man}

In this article, Cristian Tudor Popescu wonders if the film will win or will lose something using 3D space. He continues by giving examples: "The remarquable black and white movies with no sound are not of lower level than the colored masterpieces with sound. "Nosferatu" by F.W. Murnau is not less memorable then "The Shining" by Stanley Kubrick, "Modern Times" by Charlie Chaplin is not inferior to "Titanic by James Cameron, Metropolis" by Fritz Lang can face any time "Matrix» by brothers Wachowski." The essayist argues that the 3D image will exclude art because "art means abstraction. It means to make abstraction, to discard something from reality. All art is abstract."

Ce vrea de 100 şi mai bine de ani un spectator standard mediu (SSM) contra costului biletului de cinema? Vrea să râdă, vrea să plângă, vrea să fie uimit, indignat, cuprins de groază, să respire uşurat, vrea senzaţie, sentiment, stare. Vrea să simtă în cele două ore cât nu simte într-un an din viaţa lui săracă în trăire.

lată de ce cinematografia, aşa cum o cunoaştem, este, sau cel puţin a fost, 0 artă populară. Ceea ce $n$-au fost vreodată pictura, sculptura sau fotografia - efortul de imaginaţie pentru a ajunge la stare în cazul acestui tip de medium artistic static şi mut e prea mare pentru capacitatea mentală a SSM. lar în cazul artei cuvântului tipărit e şi mai greu.

Mişcarea, apoi sunetul, muzica, vocea umană, culoarea au apropiat de fiecare dată filmul de ceea ce s-ar numi realificare, recrearea realităţii pentru toate cele cinci simţuri ale spectatorului. Care să înceteze a mai fi spectator.

Acum suntem în deceniul 0, al Noii Ere 3D. Viziunea tridimensională, stereoscopică, încă un pas mare către idealul realificării complete, a fost lansată încă din anii '50, cu mijloace tehnice modeste, prea scumpe, dar concurenţa televiziunii fiind ameninţătoare, patronii din industria filmului şi-au asumat riscul. Durerile de cap şi oboseala oculară a spectatorilor siliţi să poarte ochelari grei cu o lentilă albastră şi una roşie au scos destul de repede procedeul de pe piaţă. În anii 2000 el revine sub presiunea altui mediu în plin elan: Internetul. Ca să ofere 
ceva accesibil doar în sala de cinema, investitorii s-au hotărât să reia 3D folosind noile tehnologii digitale, mult mai ieftine şi performante. După animaţiile 3D „Chicken Little" şi „Meet the Robinsons", după succesul "Călătoriei spre centrul Pământului" şi concertului U2 3D prezentat anul trecut la Cannes, anul acesta marile studiouri intră în scenă cu "Beowulf" (r: Robert Zemeckis), "Avatar" (r: James Cameron), „Up" (Disney/Pixar), "G-Force" (Jerry Bruckheimer). George Lucas are intenţia să-şi convertească 3D toate cele 6 filme Star Wars. Studiourile Dreamworks anunţă că din 2009 toate producţiile lor vor fi 3D. Calitatea proiecţiilor va fi garantată de ţipetele şi smuciturile în scaune ale spectatorilor asaltaţi de monştri, extratereştri sau cyborgi.

Întrebarea mea de cinefil: va avea de câştigat sau de pierdut filmul ca artă în spaţiul 3D? Filmele-reper ale mutului alb-negru nu sunt după părerea mea inferioare artistic capodoperelor sonorului color. "Nosferatu" de F.W. Murnau nu e sub "The Shining" de Stanley Kubrick, "Timpuri noi" de Charles Chaplin nu e sub "Titanic" de James Cameron, "Metropolis" de Fritz Lang stă oricând faţă în faţă cu "Matrix" al fraţilor Wachowski. Operaţia de colorizare a marilor filme alb-negru nu le-a îmbunătăţit câtuşi de puţin, dimpotrivă, le-a alterat estetic fundamental, ca şi cum ai vopsi o floare. Remasterizarea lor digitală creşte acuratețea imaginii, dar e 0 imagine rece, fără căldura peliculei. Cu cât e mai aproape de artă, cu atât o operă e mai greu transplantabilă de pe un mediu pe altul. De aceea, ideea de a transpune 3D capodopere 2D, care cu siguranţă va fi pusă în practică pe scară largă în următorii ani, mi se pare 0 aberaţie. În schimb, multe filme 2D de serie vor avea probabil de câştigat prin digitalizare 3D. Motivul e tulburător de simplu: filmul de artă se adresează spiritului, filmul de serie senzaţiei. 0 dimensiune în plus creează senzaţii noi, dar împuţinează grav spiritul filmului, dacă el există.
Simt nevoia să fiu în ploaia din "Camera Împlinirii Dorinţelor", cu Scriitorul, Savantul şi Călăuza prăbuşiţi în prag, ca într-un spaţiu 3D? Nu, nici gând. Nu-mi doresc ca imaginea tarkovskiană să fie mai reală, tocmai pentru că forţa ei stă în transcendenţa pe care o transmite folosind elemente de real aflate la îndemâna oricui. Nu vreau să miros transpiraţia lui Aleksandr Kaidanovski sau să pipăi paltonul purtat de Anatoli Soloniţân, asta nu mă va face să percep mai bine imaginea din sufletul lui Tarkovski, pentru că acolo, deşi nu apare nici un extraterestru cu coadă, nu e o imagine din lumea reală, e imaginea sufletului unui artist. lar sufletul lui are toate D-urile spaţiului şi timpului.

Punctul omega, punctul de fugă către care tinde realificarea, $c u$ pasul ei actual 2D-3D, exclude arta. Pentru că arta înseamnă abstracţiune. Înseamnă a face abstracţie, a înlătura câte ceva din realitate. Toată arta este abstractă. 0 maimuţă albă cufundată până la gât în apa unui lac de munte asiatic, privind lumea cu aerul unui înţelept al cărui spirit s-a desprins de trup este artă, cu toate că realizatorii extraordinarului documentar Baraka n-au influenţat în nici un fel instantaneul. Dar I-au căutat îndelung şi I-au scos din peisajul planetei, focalizândune atenţia pentru câteva zeci de secunde doar asupra lui din toată realitatea Terrei.

Sau a adăuga. Tarkovski obişnuia să vopsească pomi pentru ca peisajul să se potrivească atmosferei lui interioare. Antonioni a modificat toate culorile mediului din "Deşertul roşu" pentru ca industrialul să pară viu şi naturalul muribund, cenuşiu. Realitatea este pentru cineast asemenea culorilor din tuburi pentru pictor.

Vor apărea cu siguranță, ca în orice nou medium, şi creatori autentici în 3D, care îşi vor gândi opera de la bun început în funcţie de acest nou parametru tehnologic. Asta însă dacă va mai fi nevoie de ei, căci deja sloganul unor companii de hardware este: „Fă-ţi propriul film 3D la tine în sufragerie!". Firma PDT din Manchester oferă webcamera Minoru, care dispune de două lentile la distanţă aproximativ egală cu cea dintre ochii umani. Împreună cu un software distribuit gratuit şi o pereche de ochelari roşu-albastru, fiecare utilizator de computer îşi poate face filmul său personal 3D. Americanii de la TD Vision pun pe piaţă un codec software şi un camcorder cu care orice clip obişnuit poate fi transformat în unul 3D. Într-un viitor nu prea îndepărtat, fiecare cetăţean va putea să-şi regizeze propriul film 3D şi să fie unul dintre actori alături de hologramele din celelalte roluri. Unii nu se vor limita la sufrageria proprie, îşi vor proiecta producţiile pe scuarul din faţa blocului, ca să beneficieze şi vecinii...

Singura problemă mi se pare, dar poate vârsta să fie de vină, că pe măsură ce imaginea câştigă o dimensiune, devenind 3D, omul pierde o dimensiune, adâncimea, transformându-se într-o făptură a superficiului, bidimensională. 


\section{An uncomplete puzzle}

The young director Alexandra Badea that worked extensively not only in Romania but also in France, continuously questions the nation issue in our contemporary society. A way to adapt in this society is by zooming on the subjects of her revolt: "I project my outrage on the charactes I extract from the society, on these people we are meeting in the streets without even stop by, on those who carries in them the mark of our cracked world. I'm interested in this break and I feel it in my travels, in switching from one world to another."

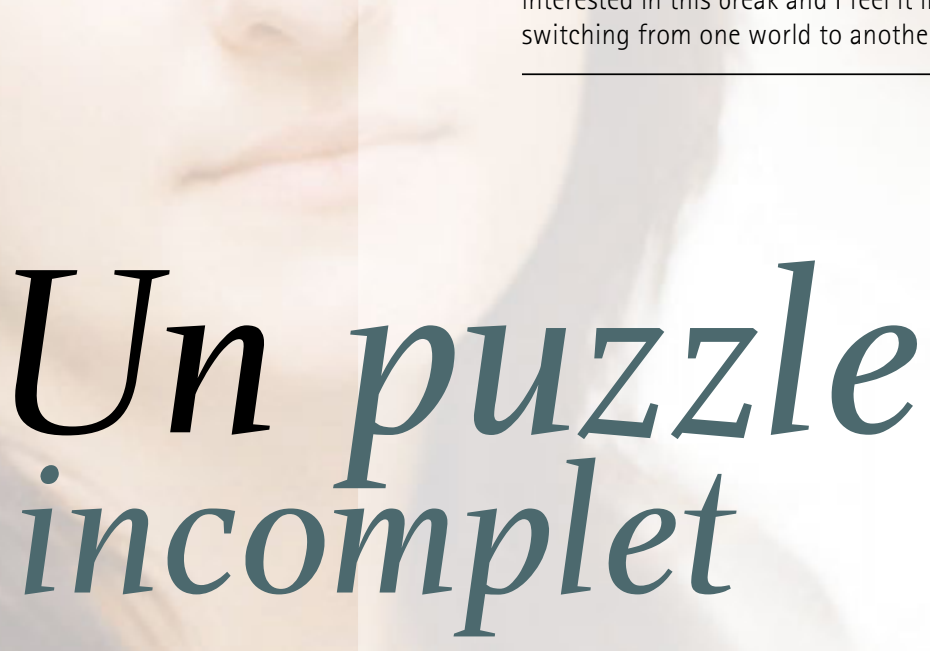

Acum şase ani am plecat din România în căutarea unei societăţi perfecte. Nu mă puteam adapta într-un sistem haotic, violent, în care individul era absorbit de grup, în care singura modalitate de a avansa era de a te încadra în curentul creditat. Am abdicat pentru că în acel moment revolta pe care societatea românească mi-o provoca era prea puternică pentru a se transforma într-un motor creativ. Simţeam nevoia să mă îndepărtez pentru un timp de block starter. A fost o fugă impulsivă. Pentru prima oară mi-am urmat instinctul până la capăt. Asta mi-a permis să rămân aproape de mine, de ceea ce mă determinase să fac teatru.

Societatea aceea perfectă nu am găsit-o. Mi-am găsit însă cu timpul echilibrul într-un „aller retour" între România şi Franţa, într-o rătăcire periodică în noi spaţii geografice din care încerc să extrag fragmente care ar putea completa puzzle-ul unei societăţ̧i utopice.

Am început să scriu târziu, cu un an înainte de momentul revenirii în România pentru un moment mai lung în care am montat "69" la Teatrul Naţional din Timişoara şi „Complexul România" la Teatrul Naţional din Bucureşti. Am început să scriu retrasând acest du-te-vino între cele două ţări, încercând să definesc noua mea identitate. $\mathrm{Cu}$ timpul am renunţat să răspund la întrebarea asta. Am renunţat să înţeleg ce înseamnă să fii român sau francez. Am renunţat să înţeleg de ce uneori lângă numele meu se pune Franţa şi alteori România. Am renunţat să înţeleg de ce nu mă identific clar cu un grup „etnic". Nu cred că aparţinem unui singur spațiu geografic şi nu cred că un spaţiu geografic ne aparţine. Cred că ar trebui să fim liberi să trăim acolo unde corpul nostru simte că trebuie să se oprească un timp. Sper ca la un moment dat frontierele să dispară. Îmi dau însă seama că suntem foarte departe de acest moment. Continuăm încă să construim ziduri pentru a diviza populaţiile lumii.

Din cauza asta trăiesc între două ţări. Din cauza asta lucrez între două ţări. E maniera mea personală de a fisura zidurile. Cred că sunt idei pe care suntem obligaţi să le formulăm şi probleme pe care nu aveam cum să le ascundem. Ar însemna să fim complici unui sistem în care individul e pe cale de a deveni cantitate neglijabilă.

Probabil că cel mai eficace mod de a găsi un acord cu societatea în care trăiesc e de "a zooma" pe probleme care mă sensibilizează şi mă revoltă. Îmi proiectez revolta în personajele pe care le extrag din societate, pe acei oameni cu care ne intersectăm pe stradă fără să ne oprim, pe cei ce poartă în ei amprenta fisurii lumii de azi. Mă interesează ruptura şi o resimt în drumurile mele, în comutarea dintr-o lume în alta.

Întoarcerea în România a corespuns cu un moment în care nişte uşi s-au deschis, în care am simţit că trebuie să intru în sistemul de care cu şase ani în urmă fugisem, pentru că numai din interiorul lui se pot schimba anumite lucruri. Absenţa asta de câţiva ani mi-a permis să identific mai bine sursele inadaptării mele la societatea românească. Despre asta vorbesc în spectacolele mele din ultimul timp. Din România îmi vine radicalitatea discursului, violenţa imaginilor, raportul tensionat cu publicul. Ritmul, conflictul, poate disperarea personajelor pe care le aduc în faţa publicului. Din Franţa am luat deschiderea faţă de alte culturi, relativizarea punctului meu de vedere, distanţarea, acutizarea simţului civic şi politic.

Am nevoie de aceste drumuri dintr-o ţară în alta pentru a mă distanţa temporar de problemele care mă revoltă în acea societate pentru a le vedea de departe, pentru a putea vorbi fără să fiu opresată de ele.

Uneori, lumea mă întreabă unde mă simt acasă. Peste tot. Acolo unde găsesc o echipă care e purtată de aceleaşi idei, care simte urgenţa de a le exprima şi de a le împărtăşi publicului. 


\section{Teatrul Masca}

Stagiune aniversară

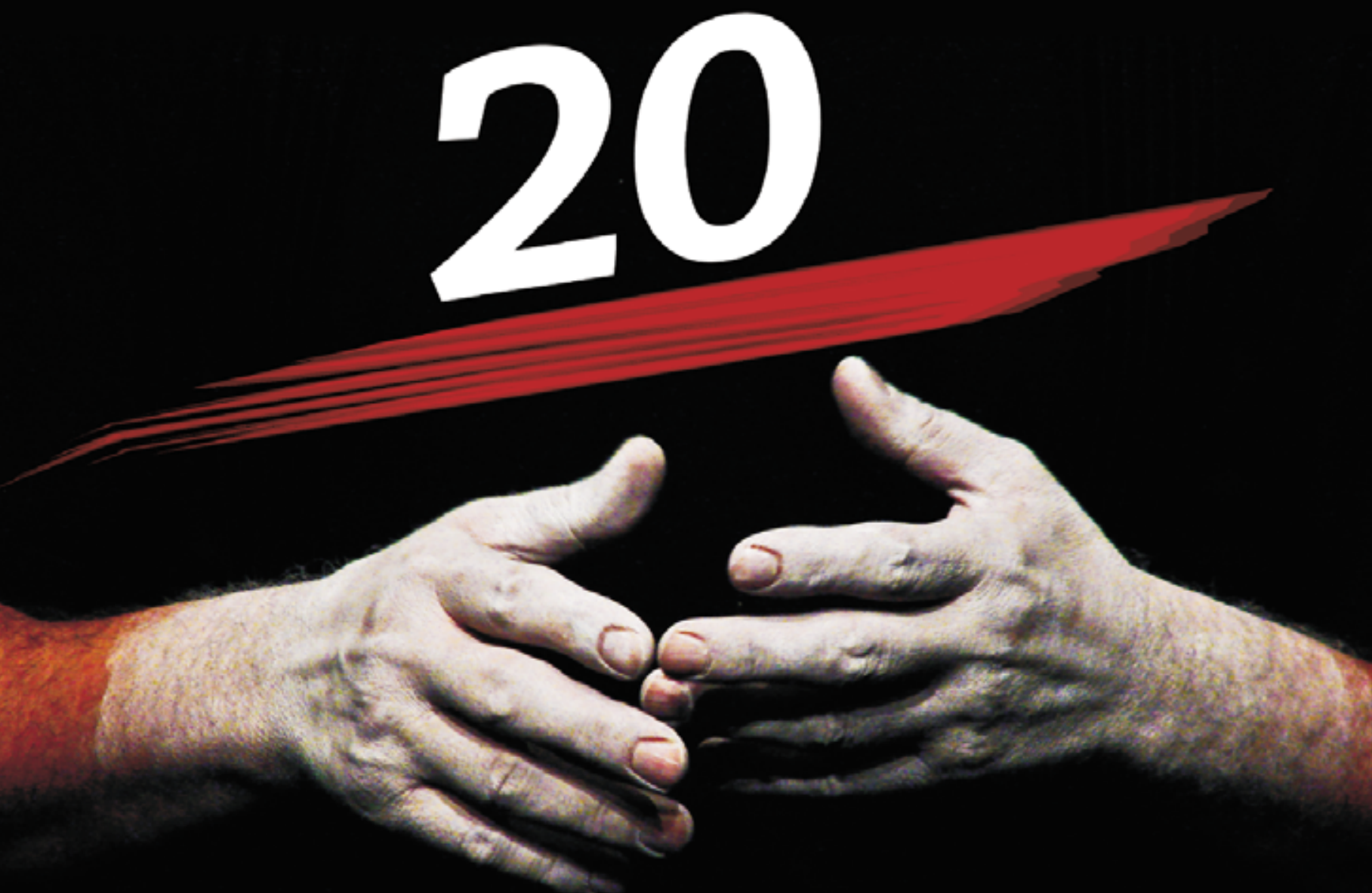

Teatrul este o ÎNTÂLNIRE. Şi, ca la orice întâlnire, mă duc cu teama de a nu o rata, căci o întâlnire nu este un mecanism bine pus la punct.

Puntea e şubredă. Tu nu ai încredere şi stai în umbra protectoare a sălii, sau în refugiul ocrotitor al mulțimii, iar $\mathrm{Eu}$, deşi sunt un bun profesionist (ruperea punții în sine nu m-ar face să mă prăbuşesc în hău), umblu cu infinite precauțiuni. Şi zâmbesc. Eu traversez Primejdia zâmbind, pentru ca Tu să ai încredere şi să-mi prinzi mîna năduşită de teamă, de speranță. Când, în sfârşit, ne-am întâlnit, râdem şi plângem ca nebunii şi, apoi, ne împrăştiem pe la suferințele noastre. Dacă cineva ne-ar fi observat de la distanță, s-ar fi mirat: "despre ce punte vorbesc ăştia, despre ce hău, că nu văd nimic".

Şi, poate, nici n-a fost, dar, fără Primejdia asta, resimțită ca o ploaie curgând în noi, degeaba TEATRUL, şi n-am putea-o lua, mâine, de la capăt. 


\section{PROMO}

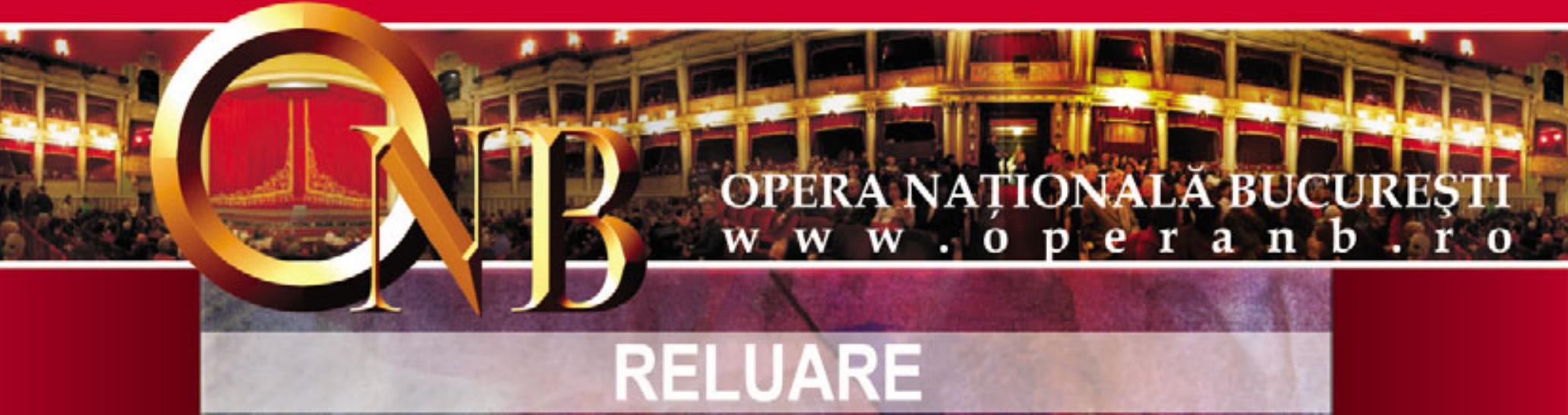

ANNA

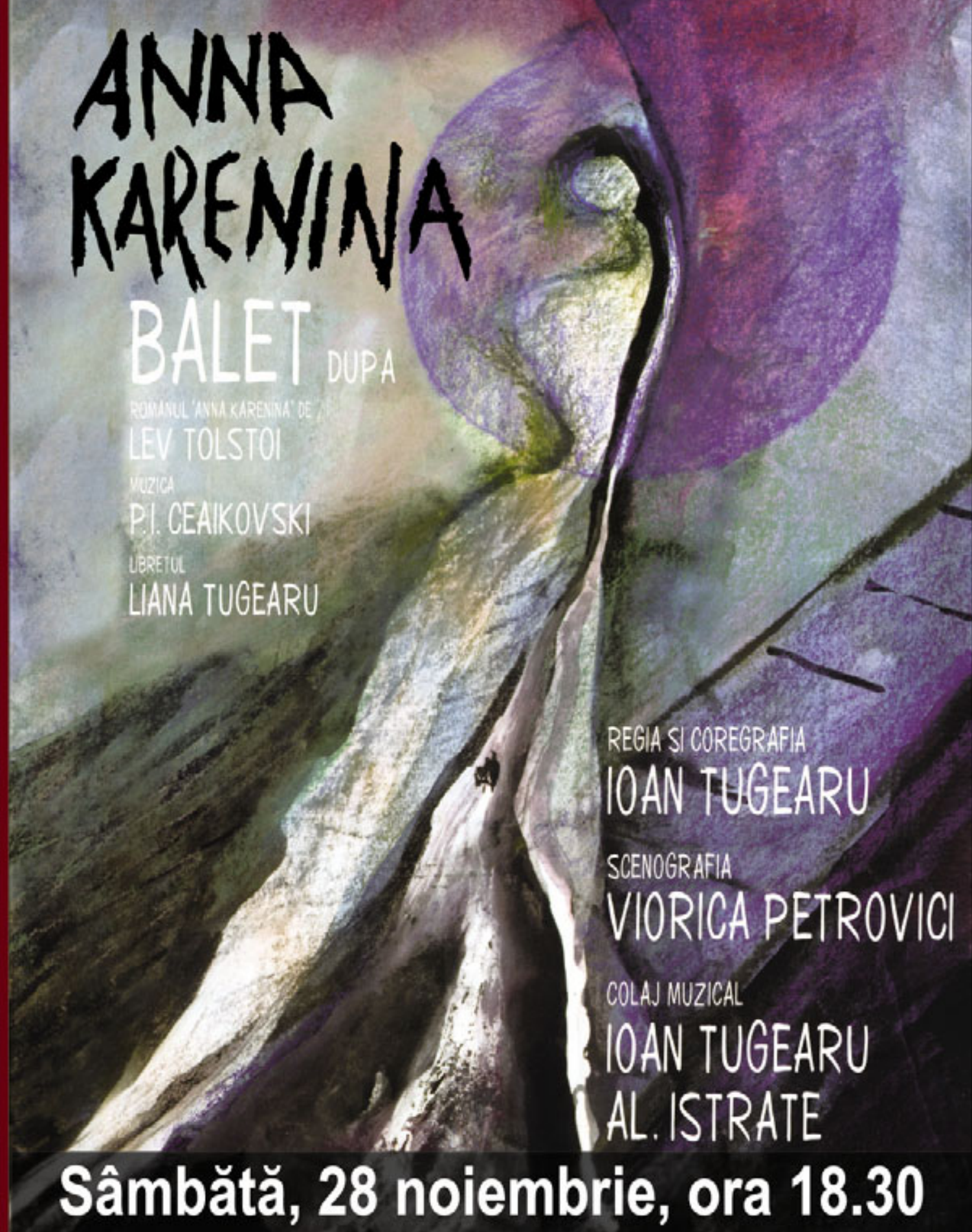

D)A $=$ DUPA OPERA
W W W
UARE 


\section{Top Three magicians at Enescu Festival 2009}

Nigel Kennedy, Murray Perahia and Natalie Dessay are here selected by Florentina Bratfanof from the very rich programme of this year Enescu festival as the first three "magicians" of classical music. The top is following the criteria of spectacular and takes into consideration the artist's capability to pass beyond interpretation and to go further to new elements as: humanity and inner joy of Nigel Kennedy; the double posture, being also the conductor and part of the orchestra, of Murray Perahia; and the constant search and the link between the opera and acting possibilities of soprano Natalie Dessay.

\section{.Top trei \\ magi \\ (a) clent \\ Florentina BRATFANOF}

\section{Nigel Kennedy}

La Nigel Kennedy am simţit umanitatea şi armonia interioară ale unui violonist care a trecut de mult de interpretarea corectă a unei compoziţii muzicale, bucurându-se cu tot corpul de orice sunet pe care îl produce cu ajutorul viorii sale. După un spectaculos concert susţinut pe scena Sălii Palatului, el a fost protagonistul unei conferinţe de presă neconvenţionale în care a acceptat senin atât critici asupra modului său de a interpreta, cât şi laude spumoase, mulţumind mereu, oferindu-le ziariştilor vin şi dând noroc cu ei.

\section{Murray Perahia}

Ştiţi cum e să-i vezi faţa dirijorului şi să simţi podeaua scenei de la Ateneu cum rezonează sub bătăile de ritm ale muzicienilor? De asta am avut parte în a doua seară în care Murray Perahia era dirijorul demiurg al orchestrei camerale Saint Martin in the Fields.

Murray Perahia a avut o dublă postură: a dirijat cântând în acelaşi timp la pian, conducând mereu orchestra într-un hăţiş de acorduri subtile, lăsând senzaţia acelei părţi din public care a avut onorea să fie plasată pe scenă că artistul înfruntă muzica şi este deasupra ei. la Festivalul Enescu 2009

Natalie Dessay

Natalie Dessay a ţinut la Bucureşti o conferinţă de presă memorabilă, farmecul său cucerindu-i şi pe cei mai pesimişti dintre criticii muzicali. Ceea ce $m$-a încântat la ea în concertul susţinut la Ateneu erau expresivitatea şi lumina ochilor şi a feţei, plusate de mobilitatea trăsăturilor, toate dublate de sinceritate şi profunzime.

În conferinţa de presă din penultima zi de festival, răspunsurile lui Natalie Dessay se întorceau mereu la nevoia sa acută de a juca rolul oferit şi nu numai de a cânta o partitură, soprana fiind acum mult mai interesată de spectacol, chiar declarând că dacă un spectacol de operă ar fi însemnat numai să cânte şi nu să joace ar fi renunţat demult la această ipostază.

\section{PROMO}
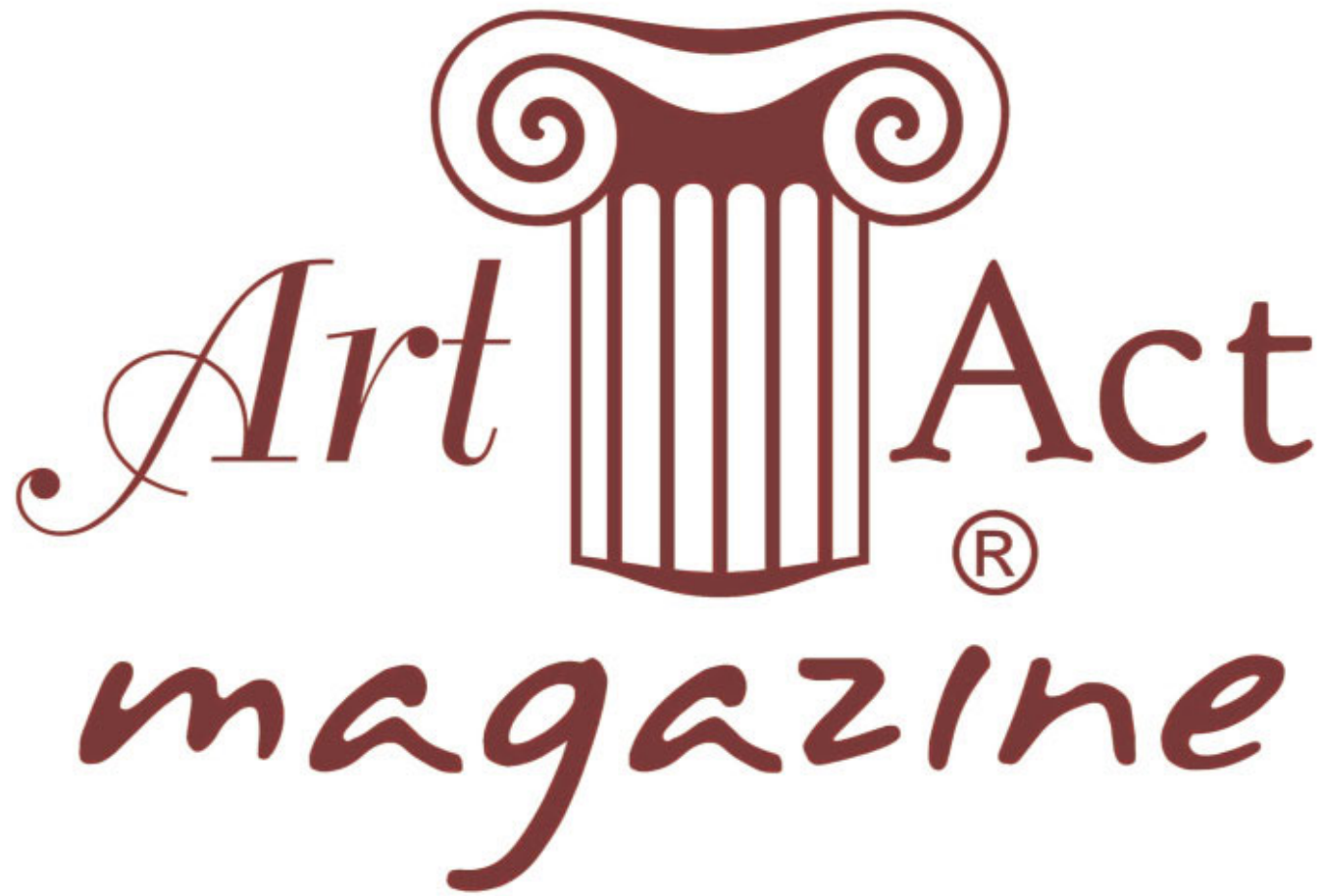

Publicatie de cultura saptaminala

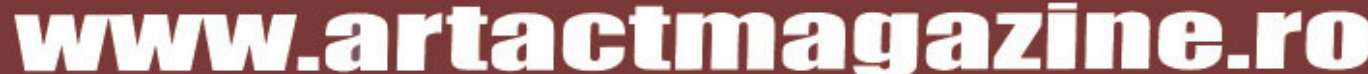




\section{PROMO}

Biletele se găsesc la casele de bilete de la:

\section{www.fnt.ro}

Teatrul Naţional, Teatrul Odeon, Teatrul L.S. Bulandra, Teatrul Mic, Teatrul de Comedie, Opera Naţională, precum și la www.bilete.ro

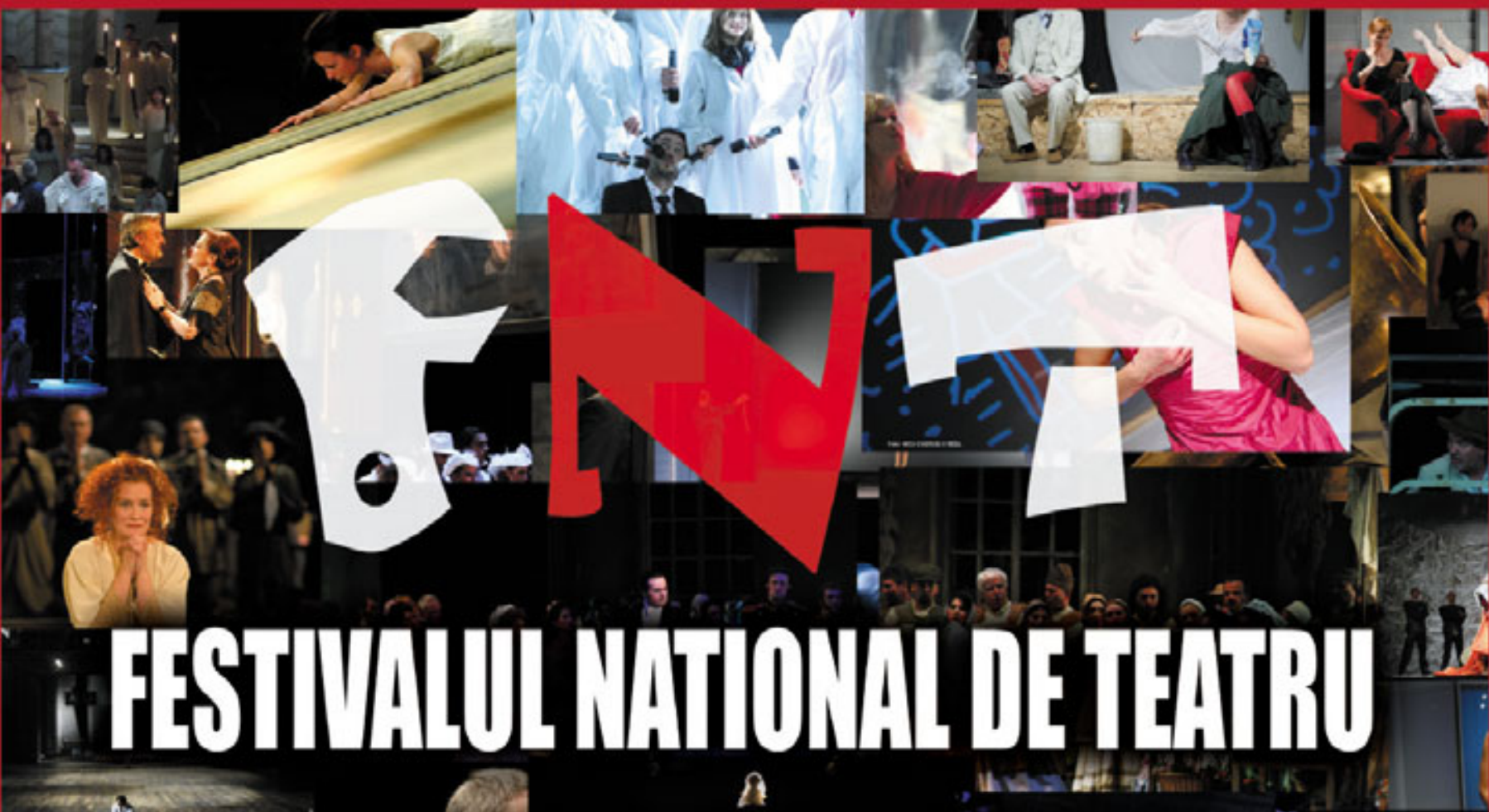

PRODUCĂTOR

라마. PUNITER

CO-PRODUC ÁTOR

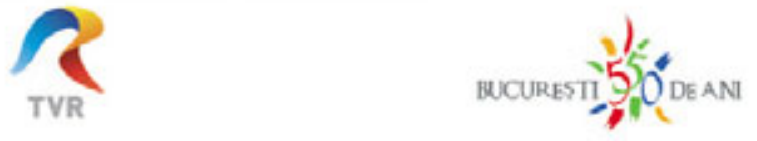

CU SPRIJINUL

中nim $\oplus$ is
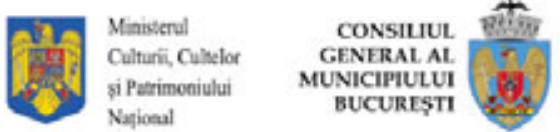

FINANTATORI

Primària

Municipiului

Bucuresti

CO-ORGANIZATORI

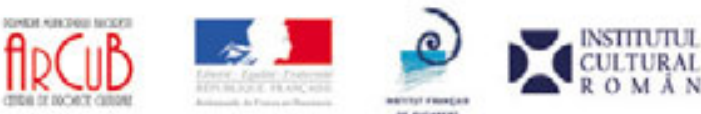

SPONSOR I loteria
romanas
Partener de tradiţie:

I $/ A=$

'IC समाणुजा
Partenerimedia: COCOR 107.3 Ð००৫. mesulo Remendia hibera 댕 fif Gindul Scena.ro 4 waisoft suplimeatul CUITURA timpulitiber $\mathrm{YZ}$. 24-Fin Cotidianul.
Partenerimedia online: PORTre mircampusur

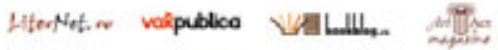
eVa.ro (189) cinemiagia

Eveniment recomandat de: JURNALII. 


\section{S-a stins din viaţă lon Cojar}

Echipa UNITER anunţă cu profundă tristeţe dispariţia, la data 18 octombrie, a domnului lon Cojar, regizor proeminent, distins pedagog şi animator al teatrului românesc. S-a retras cu o discreţie seniorială în lumea sa abstractă, impalpabilă, a ideilor pure, însingurând marea noastră familie teatrală.

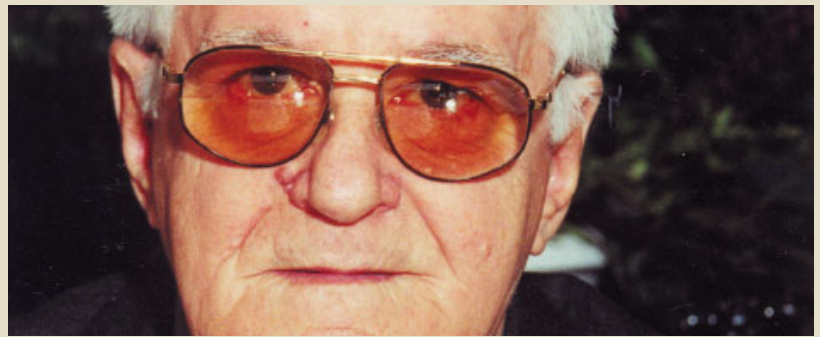

Autor, de-a lungul unei cariere de aproape şase decenii, a peste o sută de spectacole, Ion Cojar, regizor cu o extrem de vastă cultură şi cu un gust artistic rafinat, impecabil, a ştiut şi a reuşit întotdeauna să creeze pe scenă atmosferă, să transmită stare, să dezvolte un univers. Spectacolele sale, născute dintr-o inepuizabilă căldură sufletească, dintr-un sistem estetic propriu şi dintr-o ştiinţă aparte a comunicării au fost mereu inventive, pline de vervă, de sugestii, de semnificaţii. Lui Ion Cojar îi revin, totodată, prerogative spirituale de creator de şcoală, de mentor şi senior al şcolii româneşti de teatru. Autor de studii de teorie şi practică teatrală, de aprofundare a artei actorului, el a înţeles să nu se dezmintă niciodată pe sine, rămânând credincios normelor artistice în spiritul cărora s-a format şi pe care le-a îmbogăţit. A modelat, astfel, şi a impus pe scenele din toată ţara generaţii întregi de actori, descoperind talentul şi şlefuindu-I până aproape de desăvârşire. Ion Cojar a fost şi un conducător apreciat al unor instituţii teatrale importante. Sub bagheta sa, TNB a cunoscut unii dintre cei mai faşti ani ai istoriei sale. Prin întreaga sa activitate lon Cojar intră în legenda teatrului românesc.

Dumnezeu să îl odihnească în pace! 


\section{Festival de teatru, dans si imagine video}

Asociaţia ArtLink organizează în România a doua ediţie a festivalului european de teatru, dans şi imagine video TEMPS D'IMAGES, prezentându-I la Cluj începând cu acest an. Pe parcursul unei săptămâni (9-15 noiembrie 2009), festivalul prezintă spectacole din zona de teatru / dans contemporan / video / multimedia, performance-uri, workshop-uri etc.

\section{Alexandra Badea, spectacol la Paris}

Regizoarea Alexandra Badea a montat în premieră, în luna septembrie, textul său "Controle d' identite" la teatrul Le Tarmac de la Villette din Paris. Din distribuţie fac parte actori români şi francezi: Mădălina Constantin, Corentin Koskas, Răzvan Oprea, Carine Piazzi. Scenografia este semnată de Alexandra Badea, coregrafia Serge Aime Coulibaly, creaţie lumini Philippe Amblard, creaţ̧ie video Emilie Aussel. Spectacolul a fost realizat de Compania Europ'Artes în coproducţie cu Le Tarmac de la Villette şi A.R.C.A.D.I., cu susţinerea Comisiei Internaţionale a Teatrului Francofon, Institutului Cultural Român din Paris şi Art Act (România). Cu ocazia premierei, editura Arche a lansat un volum cu trei dintre textele Alexandrei Badea: „Mode d'emploi", "Controle d'identite" şi "Burnout".

\section{Teatrul Naţional Timişoara restaurează istoria}

Naţionalul timişorean iniţiază un program de recuperare pentru artă a unor spaţii istorice abandonate. În prezent, fostul manej imperial (respectiv Sala 2) şi sinagoga desacralizată din Piaţa Traian (respectiv Sala 3 Fabric) sunt recâştigate pentru cultură şi readuse la viaţă. Teatrul Naţional Timişoara beneficiază astfel, pe lângă Sala Mare, de trei săli alternative de spectacole (Sala 2, în prezent în reparaţii capitale, Sala 3 Fabric şi Sala Studio, toate aflate în clădiri istorice) şi de dotări tehnice de ultimă generaţie. Recuperarea unor clădiri istorice şi transformarea lor în spaţii teatrale, demararea procesului de modernizare şi refuncţionalizare a Palatului Culturii, precum şi crearea celei mai performante linii de producţie de teatru din România, Uzina de decoruri, sunt proiectele majore de şantier ale Teatrului Naţional Timişoara.

\section{Zece ani de underground}

La începutul lunii octombrie s-au împlinit 10 ani de la înfiinţarea Programului „underground" al Teatrului Ariel din Târgu Mureş, aniversare marcată cu prezentarea în premieră a spectacolului "SSS" de Gavril Cadariu.
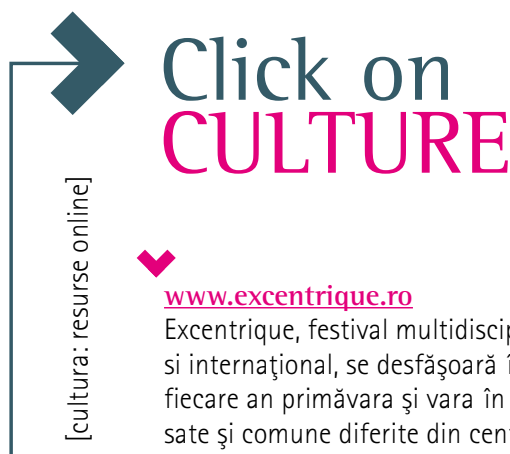

www.excentrique.ro

Excentrique, festival multidisciplinar si internaţional, se desfăşoară în fiecare an primăvara şi vara în sate şi comune diferite din centrul Franţei. Programul acestuia variază de la spectacol la arte plastice, de la literatură la cinema, de la evenimente de urbanism la gastronomie, schimbând rutina vieţii unor regiuni prea departe de centrele culturale. Se numeşte Excentrique din cauză că se axează pe proiecte inovatoare care asociază limbajul formelor populare cu cel al scriituri contemporane. Site-ul festivalului este bine structurat şi clar, sunt multe fotografii la fiecare din cele 11 locaţii din acest an, unele într-adevăr impresionante în parte datorită spectatorilor numeroşi şi a puzderiei de copii.
Cultura a intrat demult în lumea virtuală a Internetului. Rubrica îşi propune să scoată în "lumina" Scenei.ro site-uri care pot ajuta cititorul să îşi clarifice unele teme sau să determine alte căutări, să-şi satisfacă pofta de a citi/vedea/asculta şi altceva accesibil prin acest mediu.

\section{Florentina Bratfanof}

\section{www.fnt.ro}

Cu toate că are un fundal negru, site-ul Festivalului Naţional de Teatru nu este sumbru, ducându-ne mai degrabă cu gândul la întunericul care există în sală înaintea începerii unui spectacol.

Elementul de dinamism al site-ului este un inel mobil prin care "curg" fotografii din evenimentele care I-au format. Cu o versiune în limba engleză la fiecare categorie şi spectacol din Festival, www.fnt.ro dorește să deschidă spaţiul teatrului românesc, mai ales prin Romanian Showcase 2 şi cele 5 spectacole debutante, unei lumi oprite de barierele limbii. http://infant.eunet.yu

Site-ul e simplu, aşa cum este şi structura programului, dar foarte frumos vizual. În fiecare an, Casa de Cultură din Novi Sad, Serbia, deschide porţile studenţilor - graficieni din oraş - pentru a se lua la întrecere în realizarea graficii din anul respectiv. Câştigătorul se alege astfel cu recunoaştere şi bani, iar festivalul cu o imagine fresh care este folosită pe site, catalog, afiş, machete. Astfel, INFANT Festival, declarându-se a fi un mijloc de promovare a tendinţelor noi în teatru şi aducând teatrul experimental din toată lumea, cu discuţii uneori foarte contradictorii despre semnificaţii, categorisiri etc. promovează şi alte forme ale artei, într-un oraş situat la o oră de capitala Serbiei, Belgrad, dar cu mare potenţial atât din punct de vedere teatral, cât şi la nivelul publicului interesat de experiment.

Festivalul are loc în fiecare an între 25 iunie şi 3 iulie.

\section{Click on culture: festivals}

On: e can find here several links connected to European festivals: Excentrique @ www.excentrique.org in Central France, a good example about a manner of education for the people living far from big cultural centers, another festival is focused on experiment and new ways of expression in the beautiful town of Novi Sad, Serbia: - INFANT Festival @ http://infant.eunet.yu, and the third is the website of Romanian National Theatre Festival that clearly developed in the last two years, becoming more dynamic and more alive - www.fnt.ro. 


\section{Romanian \\ Showcase 2009}
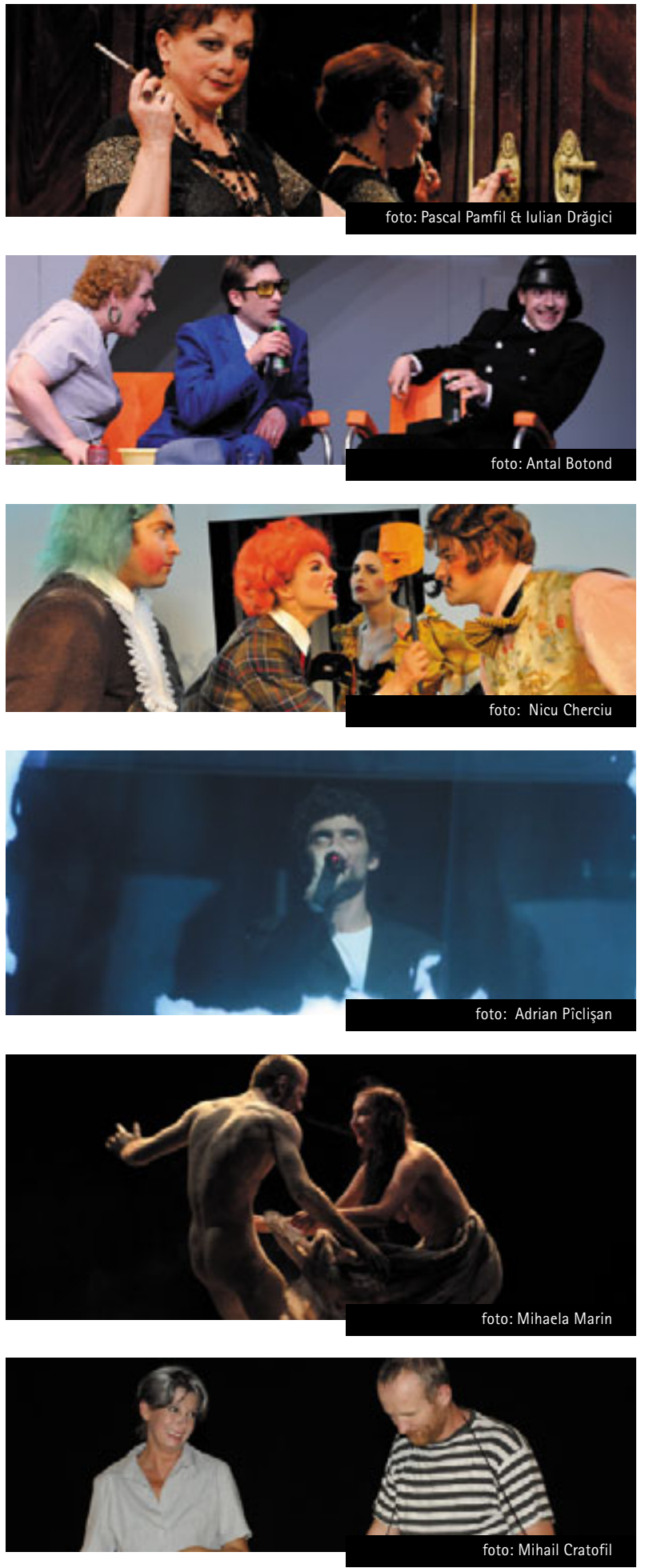

Zoika's Apartment by Mikhail Bulgakov, directed by Alexandru Tocilescu; Comedy Theater, Bucharest

Tocilescu's most recent show, "Zoika's Apartment" by Bulgakov at Comedy Theater, continues the series of theatrical "research" on the effects of communism on humanity. The director chose to treat the wounds of the past with a hefty dose of humor, knowing very well how to make the transition from comical and sometimes grotesque episodes to distressful moments. The show features a few excellent actors: Virginia Mirea, George Mihaita, Gelu Nitu.

The Bald Soprano by Eugene lonesco, directed by Alexandru Dabija; German State Theater, Timisoara - IONESCO EVENT

Dabija outdoes himself with this chronicle of the absurdness of married life, rendered in the key of a detective story. The set, costumes, "vintage" music and actors' style of playing place the performance in a charming "retro" area only to enhance the cynicism in the text. A very young team from the ambitious German theater plays the director's game to rediscover lonesco for a 2009 audience.

The Bald Soprano by Eugene Ionesco, directed by Tompa Gabor; Lucian Blaga National Theater, Cluj - IONESCO EVENT

More than a decade ago, a "Bald Soprano" made in Romania, but spoken in Hungarian, was traveling across Europe, invited everywhere and laying the foundations of the director Tompa Gabor's international career. Now, the director of the Hungarian Theater in Cluj has put out a remake in Romanian of his famous "Soprano", a hundred years after the birth of the playwright whose works fascinates him.

How Barbie Gets Through the World Crisis by Mihaela Michailov, directed by Alexandra Badea, Mihai Eminescu National Theater, Timisoara There aren't any dramatis personae, scripts, conflict, dialogue or climax. But the text has humor and irony, and the stage solutions are very modern, thus leading to a confrontation of ideas that is very contemporary from all points of view. Why should we pretend to "play at" theater, invent characters who say what we think, or pretend not to see how obsolete the thinking patterns are of some stage directors who keep trying to reinvent the classics - seem to say the young authoresses. In a sort of hyper-modern lab, an experiment takes place that focuses on the typologies of today's world.

The Epic of Gilgamesh, written and directed by Dragos Galgotiu, Odeon Theater, Bucharest

An entire world is built on stage, with its atmosphere of a legend: archetypal characters enter and exit, surging to life from memories of world literature lessons, instilling the feeling that one witnesses grandiose events. The show can be viewed without reserve as a super-production, yet a question arises: can theater compete with film? Dragos Galgotiu and his team, made up of Andrei Both (set design), Doina Levintza (costumes), Alexandru Radvan (sculptures), Silvia Calin (choreography), answer categorically: yes. This may be seen separately in each one's remarkable contribution.

Beautiful by Jon Fosse, directed by Vlad Massaci;

Toma Caragiu Theater, Ploiesti

A reprise of a theme as old as the world, in a style that bears the mark of the greatest Norwegian playwright, but also the mark of a duo - the stage director Vlad Massaci and the set designer Andu Dumitrescu - who dislike crowding means and ideas together, and believe in the power of things told simply and directly. "Beautiful" makes one's heart sink with the force of an ancient tragedy. 
The Tempest by William Shakespeare, directed by Cristi Juncu;

Toma Caragiu Theater, Ploiesti

Cristi Juncu's "Tempest" is a chamber show - no pejorative implied. It is like a chamber concert, an acoustic one, in which sounds are produced "openly" and tricks are there to be seen, without any pretense that magic is coming from some higher place. But magic really comes this way, just as it could have in other, different ways. Because Juncu's chamber show has tension, suspense, surprises, and, above all, humor.

Joan and the Fire by Matei Visniec, directed by Catalina Buzoianu:

Comedy Theater, Bucharest

Visniec's play is a typical theater-in-theater one, as in the midst of the company rehearsing a show about Joan of Arc emerges, out of the blue, Joan herself. Naturalness and simplicity are the keys of the young actress Dorina Chiriac's performance, a most authentic embodiment of the Virgin of Orleans. The actress, who was nominated with this role for UNITER's best actress award has an excellent counterpoint on stage in the hyper-energetic Marius Manole as the stage director of the show in the show.

Krum by Hanoch Levin, directed by Cristian Theodor Popescu;

National Theater, Targu Mures

The story of Krum's non-painful failure is told in a surprising acting space that plays intelligently with perspectives, suggesting that it always depends where one is looking from when one judges a person's failures - or success. The Theodor Cristian Popescu-Andu Dumitrescu duo involves the spectator by breaking the old rules concerning the distance between the stage and the audience, making an implicit declaration in favor of debate-theater, one that needs feedback from the audience.

Black Milk by Vassily Sigariev, directed by Claudiu Goga; Sica Alexandrescu Drama Theater, Brasov

The contemporary world is declining, one can hear more and more often around. This show can help us see how low a human being can actually bend, and how (if) it can be saved. Starting from the realistic play with mystical accents of one of the most appreciated Russian dramatists today, the stage director Claudiu Goga pleads for bringing to light whatever humaneness is left in us.

Lear by William Shakespeare, directed by Andrei Serban;

Bulandra Theater, Bucharest

The feminine version of "Lear" by Andrei Serban at Bulandra Theater surprises with an unexpected, bold, yet justified vision of the stage director, who sees the land given by Lear to his daughters as Romania itself, whose map is actually torn off and pieces are offered to each of them. Mariana Mihut puts up an ageless Lear, moving in a credible way from blind self-importance to belated illumination and wisdom, exiting life after having understood a few essential truths, whereas the same cannot be said about the majority of people.

Lucia is skating by Laura Sintija Chernyauskaite, directed by Radu Afrim; Andrei Muresanu Theater, Sf. Gheorghe

The style of this authoress, with poetic digressions and scenes of evasion from reality, is a perfect match for Afrim's style as a stage director, who adds a necessary touch of sparkling comicality. Once again the excellent instinct of the stage director can be noticed halting at the right moment on the tempting slope of lyricism, stopping short of falling into pathos through an inspired comical counterpoint. In this case, the result is a powerful, brisk show despite its subject, and perfectly capable of touching the right chord of a contemporary audience.

Danton's Death by Georg Buchner, directed by Mihai Măniuţiu; Hungarian State Theater, Cluj

The stage director Mihai Măniuţiu takes Georg Buchner's „Danton's Death" and the French Revolution from which it starts as a pretext to analyze the implications of the revolution at the individual's level. His show has the force of a discourse that sifts out the power games from the intimacy they tear apart, with the participation of a company of consummate professionals who go onstage without reserves to captivate the audience.
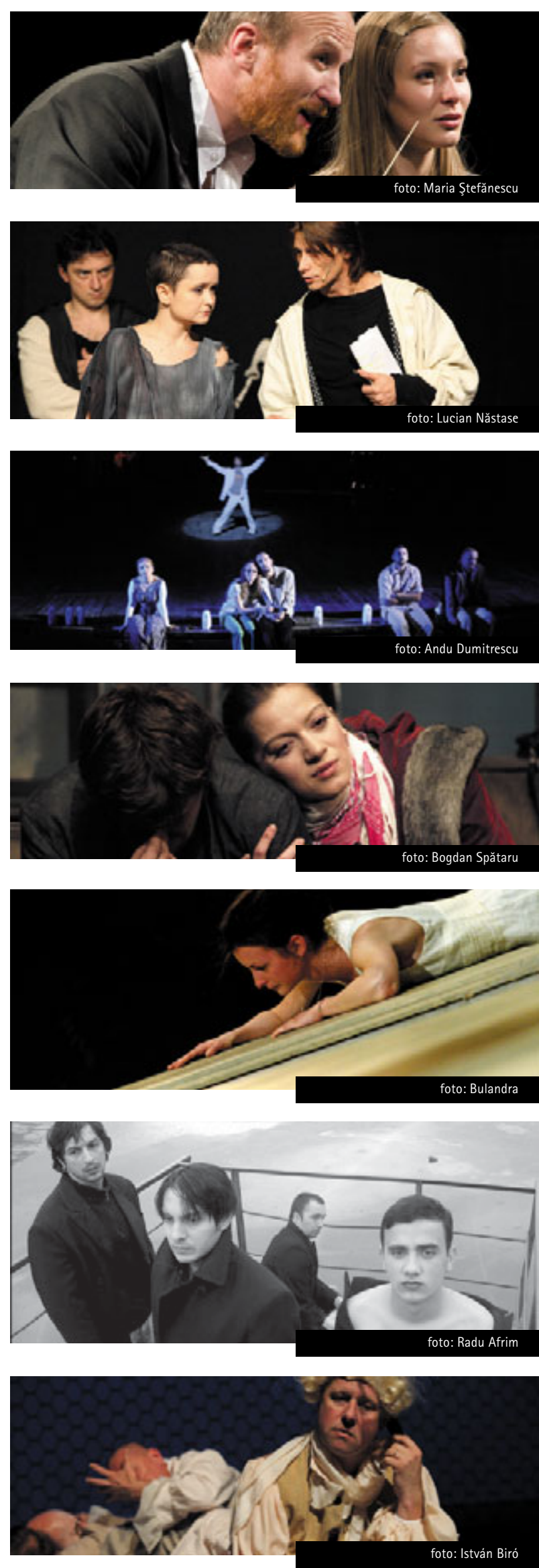

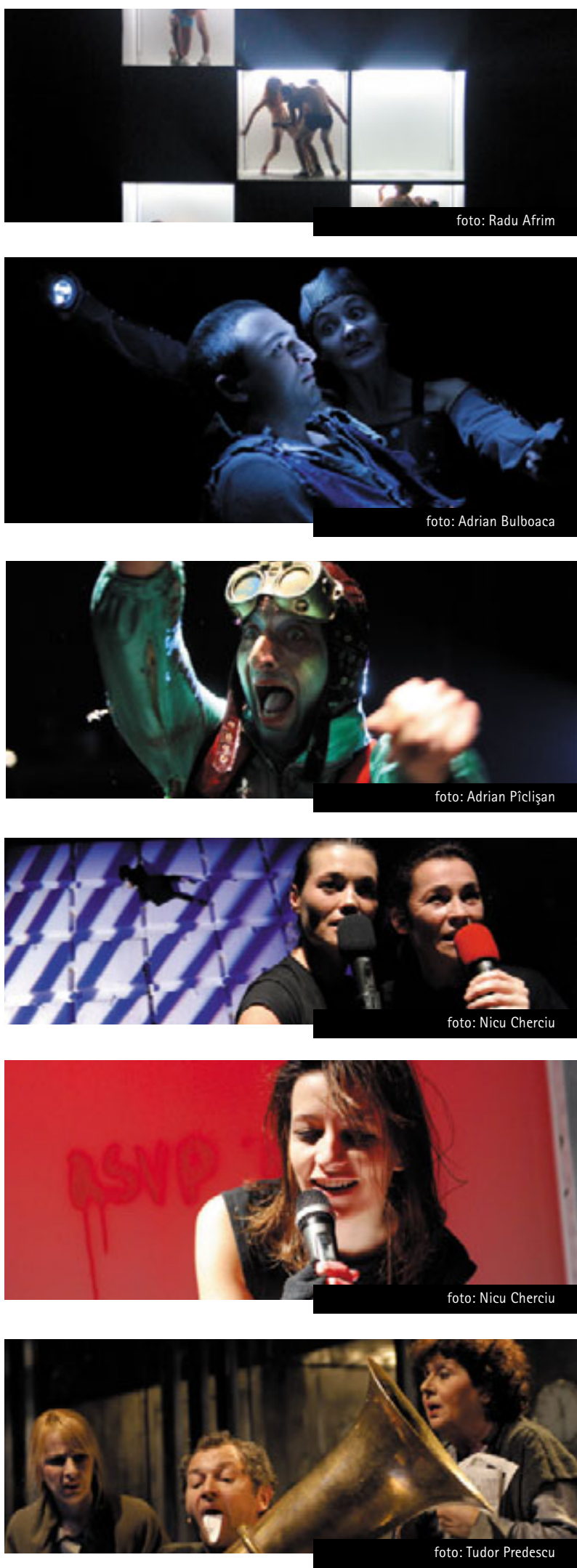

The Pillowman by Martin McDonagh, directed by Radu Afrim; Maria Filotti Theater, Braila

The performance nominated for UNITER's best direction award is a dynamic show in which choreography and music play an essential role, without diminishing its intensity and profoundness, given chiefly by the actor playing the main part, Eugen Jebeleanu, but also by group moments. The wriggling of the young, almost naked bodies apparently confined in the superposed cubes, as in a honeycomb bathed in blue light, is the graphic leitmotif of the show - one of breathtaking beauty.

FastforwardRewind, a show by Gianina Carbunariu; Little Theater, Bucharest

Made up of separate scenes dealing with painful subjects of the day seen through the deforming lens of time - the virulent campaign against smoking, in-vitro fertilization, global warming, meat consumption - the show produces an unusual "mise en abyme" of these subjects, subtly forcing each spectator to look at each of them in his or her own intimate self. The stage director's role falls into second place out of the playwright-stage director's wish to tone down the harshness of the subjects through high-flown irony, visible in the style of acting and in the set that childishly imitates the visual elements of SF productions.

The Winter's Tale by William Shakespeare, directed by Alexander Hausvater; Mihai Eminescu National Theater, Timisoara

The audience are seated in the center of the acting space, on swiveling chairs, so that they may choose which scene to watch as the show unfolds. Acting takes place on all four sides, representing different geographies. Full of dynamism, energy, color and surprising solutions - such as announcing the happy end of the play in a press conference, or the songs sung by the chorus that plays the role of "time" - "The Winter's Tale" show, in the new translation by one of the best young dramatists of today, Peca Stefan, is one of the important events of the theatrical year in Romania.

Psychosis 4.48 by Sarah Kane, directed by Mihai Măniuţiu; Lucian Blaga National Theater, Cluj

Music is the mainstay of the show: the lunatics' choir sings now a funeral march, then a grim lullaby sounding as if whispered by a pedophile, and then a "happy hours" jazz standard to which the three suicides dance. The threecharacter construction conceived by Mihai Măniuţiu shifts the accent from the main character onto the group, dispersing madness to turn the show into a distant analysis of a psychotic personality.

Psychosis 4.48 by Sarah Kane, directed by Razvan Muresan (RNTF ex-debut); Lucian Blaga National Theater, Cluj

Reading the text in a realistic key, Razvan Muresan makes the character - in the wake of a fierce fight with its own demons - poetically evade at the end from this stifling reality, through the image of the young woman singing at the microphone dropped from the ceiling. A sad song, like an epilogue written in her own hand. An impressive performer of a role divided into different lines seeming to come from different voices - an effect of the split personality of the sick woman, the young actress Patricia Boariu changes entirely as the show unfolds.

The Suicide by Nikolai Erdman, directed by Felix Alexa;

National Theater, Bucharest

The role created by Erdman is a perfect mirror for the complex personality of one of the symbol artists of Romanian stage today, the actor Dan Puric. The box-office success of the show, is mainly due to the protagonist, who has become a kind of expressive effigy of human suffering in which anyone can recognize at least one bit of one's self. 
Three Sisters by A. P. Chekhov, directed by Ada Lupu:

Mihai Eminescu National Theater, Timisoara

The stage director Ada Lupu instilled in the characters a state of exaltation, insisting on it precisely because it is the specific trait of Chekhov's characters that makes them our contemporaries. All the aspirations that slowly die out in them make these young, beautiful people exult and shine - not actually burn, but flicker a little, like fireworks that will inevitably become extinguished. Apart from the transformed acting space and Velica Panduru's set and costumes, the actual strong point of the show consists in the actors themselves and the precise map of the relations between characters drawn by the stage director with their help.

Three Sisters by A. P. Chekhov, directed by Tompa Gabor;

Hungarian State Theater, Cluj

Classical beauty in a show that remakes the atemporal world of the three

Chekhovian sisters and their touchingly perfect world at the beginning

- comfortable and warm, filled with dearly loved objects and dominated by the memory of the father (incarnated on stage by an enormous dummy), a world invaded as early as the end of the first act by the "soldiers' choir", recurring obsessively at key moments during the show. The merit of the set designer Andrei Both is that he has built a live set, one that changes from one moment to the next, following the ideas about the continuous shattering of this perfect little world.
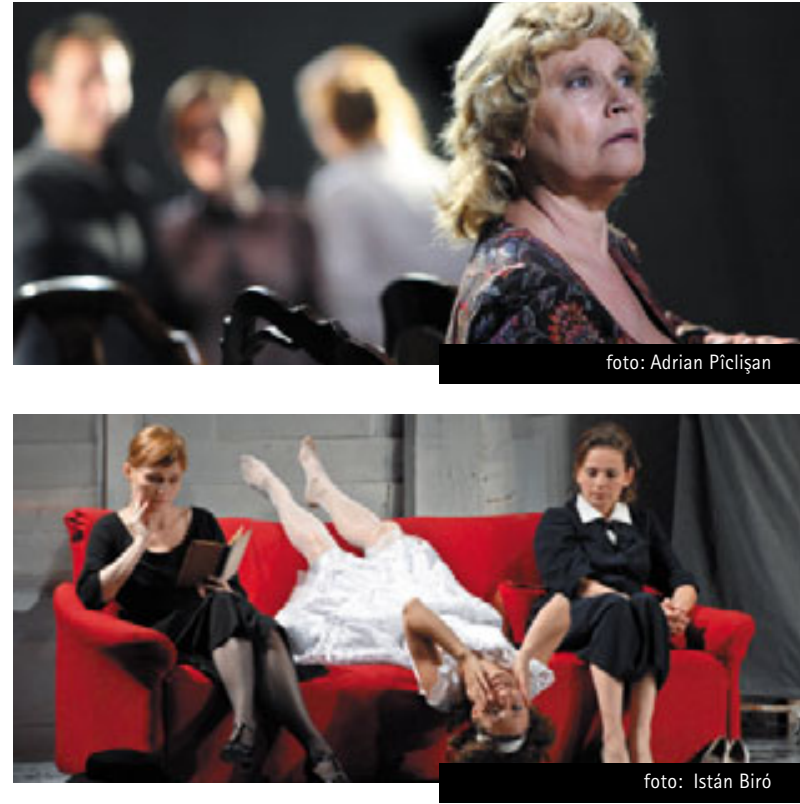

\section{Debut}

Alexandru Mihaescu: Pool. No Water by Mark Ravenhill, German State Theater, Timisoara

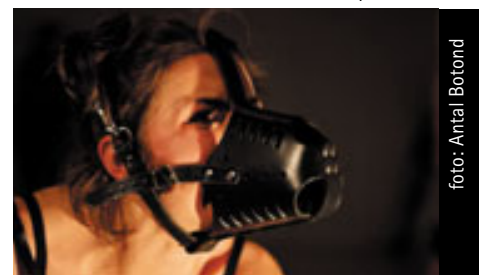

The Concretes after Vladimir Sorokin, Luni (Monday) Theater at Green Hours

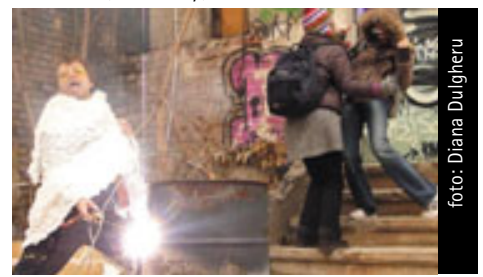

Felix Crainicu: Hippies and Bolsheviks by Amiel Gladstone, Arca Theater, La Scena Club

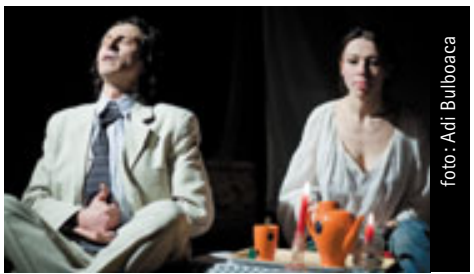

David Schwartz:

Make Room! by Mihaela Michailov, Luni (Monday) Theater at Green Hours

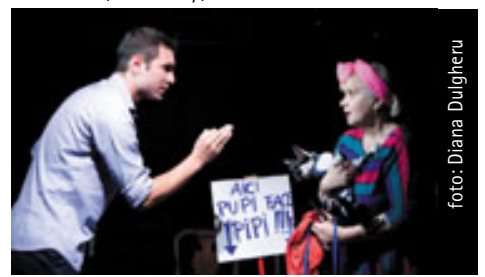

Romania! I kiss you. by Bogdan Georgescu, Vasile Alecsandri National Theatre lasi

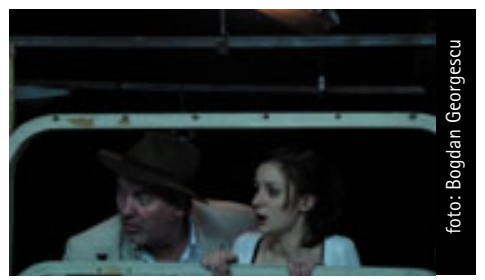


Vorba de cultituă la Radio Romantla Gurftural

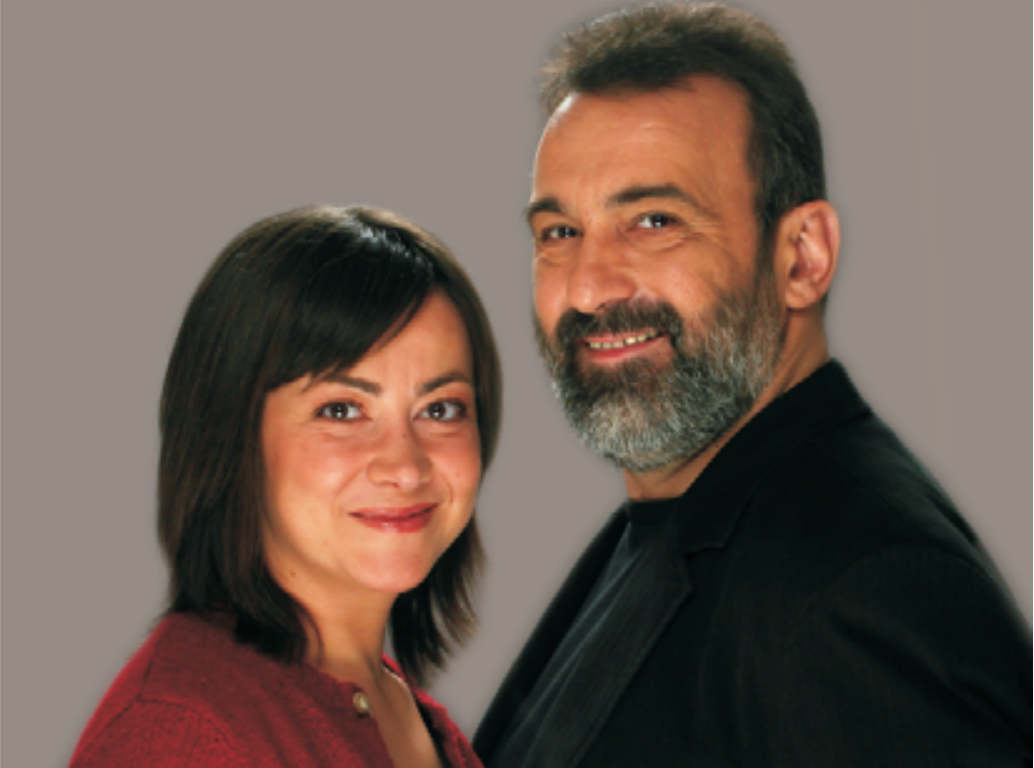

cu Ema Stere şi Attila Vizauer luni-vineri de la 12 www.cultural.srr.ro

THESENDS
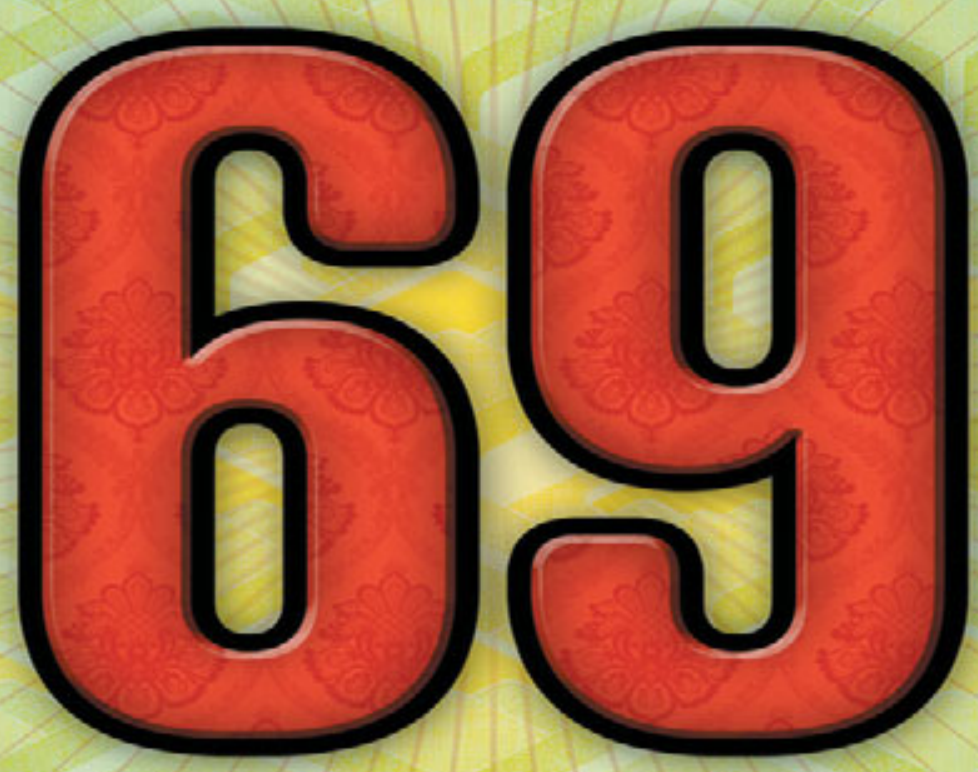

ÎN ORICE POZIȚIE O IEI,

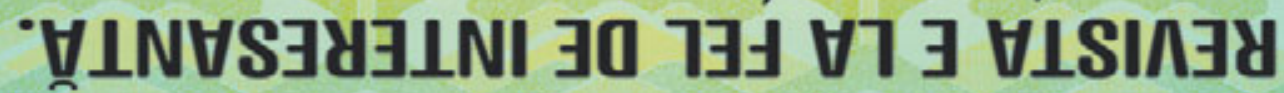

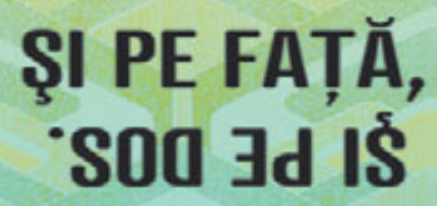

EDPTISERI 
Luni, 2 nov. | Metri, 3 nov. ora 18 TNB, Sala Âtelier f. T $\boldsymbol{T}^{2009}$

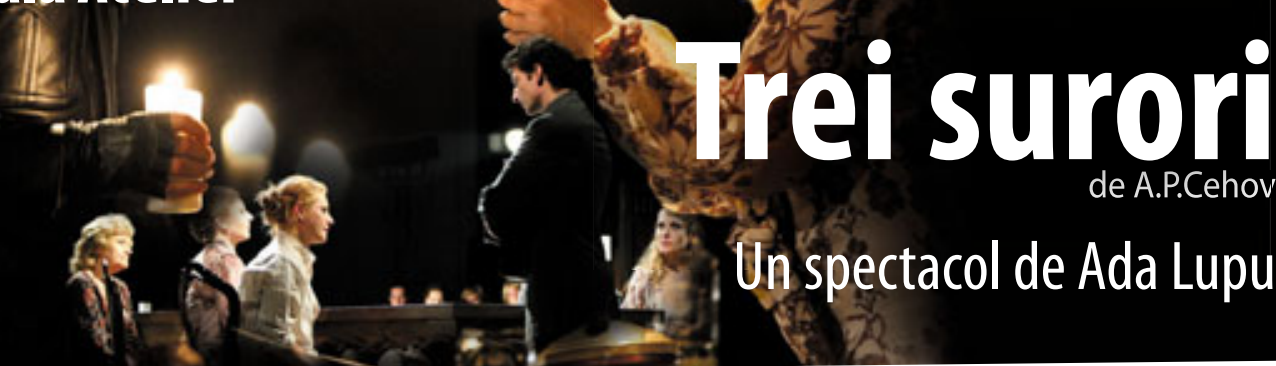

Foto: Adrian Pîclişan
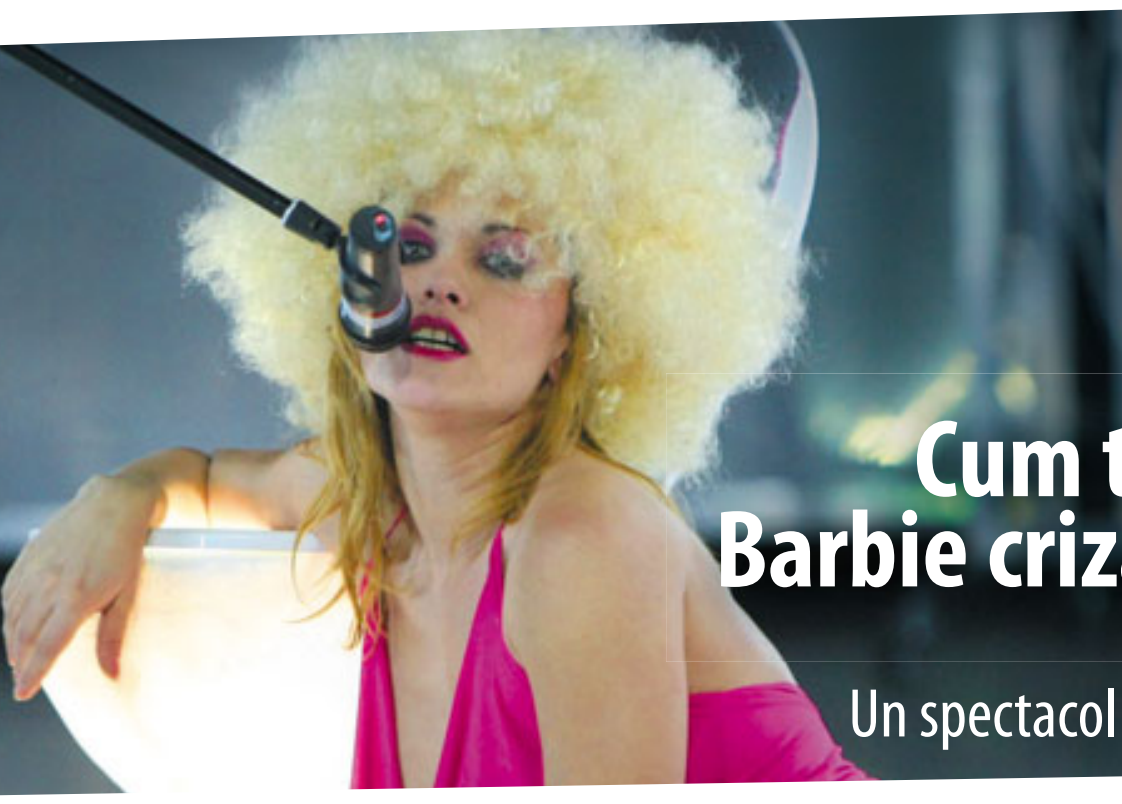

TNB, Sala Mare f $\boldsymbol{T}^{2009}$

f: $\boldsymbol{T}^{2009}$

Duminică, 8 nov.

ora 17 | ora 22

TNB, Sala Mare

Povestea de iarnă de William Shakespeare

Un spectacol de Alexander Hausvater

Barbie criza mondială de Mihaela Michailov

Un spectacol de Alexandra Badea

\section{cum traversează}

